\title{
Metamorphic and geochronogical study of the Triassic El Oro metamorphic complex, Ecuador: Implications for high-temperature metamorphism in a forearc zone
}

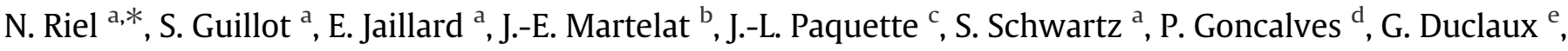 \\ N. Thebaud ${ }^{\text {f }}$ P. Lanari ${ }^{\text {a }}$, E. Janots ${ }^{\text {a }}$, J. Yuquilema ${ }^{\mathrm{g}}$ \\ a ISTerre, University Grenoble I, CNRS, 1381 rue de la Piscine, BP53, 38041 Grenoble, France \\ b Laboratoire de Géologie de Lyon, University Lyon I, CNRS, 69622 Villeurbanne Cedex, France

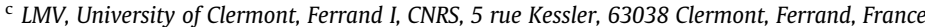 \\ d LCE, University of Franche, Comté, CNRS, 16 rue de Gray, 25030 Besançon Cedex, France \\ e CSIRO Earth Science and Resource Engineering, Earth Sciences Centre, 11 Julius Avenue, North Ryde, NSW 2113, Australia \\ ${ }^{\mathrm{f}}$ Centre for Exploration Targeting, University of Western Australia, 35 Stirling Highway,Crawley WA 6009, Australia \\ ${ }^{g}$ Facultad de Geología y Petroleos, Escuela Politécnica Nacional, E-11 253, Quito, Ecuador
}

\begin{abstract}
In the forearc of the Andean active margin in southwest Ecuador, the El Oro metamorphic complex exhibits a well exposed tilted forearc section partially migmatized. We used Raman spectroscopy on carbonaceous matter (RSCM) thermometry and pseudosections coupled with mineralogical and textural studies to constrain the pressure-temperature $(P-T)$ evolution of the El Oro metamorphic complex during Triassic times. Our results show that anatexis of the continental crust occurred by white-mica and biotite dehydration melting along a $10 \mathrm{~km}$ thick crustal domain (from 4.5 to $8 \mathrm{kbar}$ ) with increasing temperature from 650 to $700{ }^{\circ} \mathrm{C}$. In the biotite dehydration melting zone, temperature was buffered at $750-820{ }^{\circ} \mathrm{C}$ in a $5 \mathrm{~km}$ thick layer. The estimated average thermal gradient during peak metamorphism is of $30^{\circ} \mathrm{C} / \mathrm{km}$ within the migmatitic domain can be partitioned into two apparent gradients parts. The upper part from surface to $7 \mathrm{~km}$ depth records a $40-45^{\circ} \mathrm{C} / \mathrm{km}$ gradient. The lower part records a quasi-adiabatic geotherm with a $10{ }^{\circ} \mathrm{C} / \mathrm{km}$ gradient consistent with an isothermal melting zone. Migmatites $\mathrm{U}-\mathrm{Th}-\mathrm{Pb}$ geochronology yielded zircon and monazite ages of $229.3 \pm 2.1 \mathrm{Ma}$ and $224.5 \pm 2.3 \mathrm{Ma}$, respectively. This thermal event generated S-type magmatism (the Marcabeli granitoid) and was immediately followed by underplating of the high-pressure low-temperature (HP-LT) Arenillas-Panupalí unit at 225.8 $\pm 1.8 \mathrm{Ma}$. The association of high-temperature low-pressure (HT-LP) migmatites with HP-LT unit constitutes a new example of a paired metamorphic belt along the South American margin. We propose that in addition to crustal thinning, underplating of the Piedras gabbroic unit before $230 \mathrm{Ma}$ provided the heat source necessary to foster crustal anatexis. Furthermore, its MORB signature shows that the asthenosphere was involved as the source of the heat anomaly. S-type felsic magmatism is widespread during this time and suggests that a large-scale thermal anomaly affected a large part of the South American margin during the late Triassic. We propose that crustal anatexis is related to an anomaly that arose during subduction of the Panthalassa ocean under the South American margin. Slab verticalization or slab break-off can be invoked as the origin of the upwelling of the asthenosphere.
\end{abstract}

\section{Introduction}

While the generation of HP-LT rocks, especially blueschist facies assemblage, is characteristic of a subduction setting (e.g., Ernst, 1988; Guillot et al., 2009), HT-LP rocks can be produced in a wide range of geological settings. In modern belts, $H T-L P$ rocks and associated crustal anatexis (S-type magmatism) are typically generated in

\footnotetext{
* Corresponding author at: Université of Grenoble I; CNRS, Institut des Sciences de la Terre, 1381 rue de la Piscine, BP53, 38041 Grenoble, France. Tel.: + 33 476514057; fax: +33476514058 .

E-mail address: a.nicolas.riel@gmail.com (N. Riel).
}

collisional orogens (Hodges, 2000). In such a setting, HT conditions are reached either by crustal thickening or by post-orogenic collapse (Gardien et al., 1997). Crustal magma generation occurs on a timescale of 10 to $30 \mathrm{Ma}$ and can produce large volumes of granites (Thompson and Connolly, 1995). In a subduction context, granitoids are usually of I-type and are not associated with HT-LP metamorphism, especially in a forearc setting (Brown, 2007; Huppert and Sparks, 1988).

In the present forearc region of the Andean margin of southwest Ecuador, the El Oro metamorphic complex (Fig. 1) exhibits a continental sequence composed of metasediments (El Tigre and La Victoria units), partially molten metasediments (La Bocana unit) and intruded 


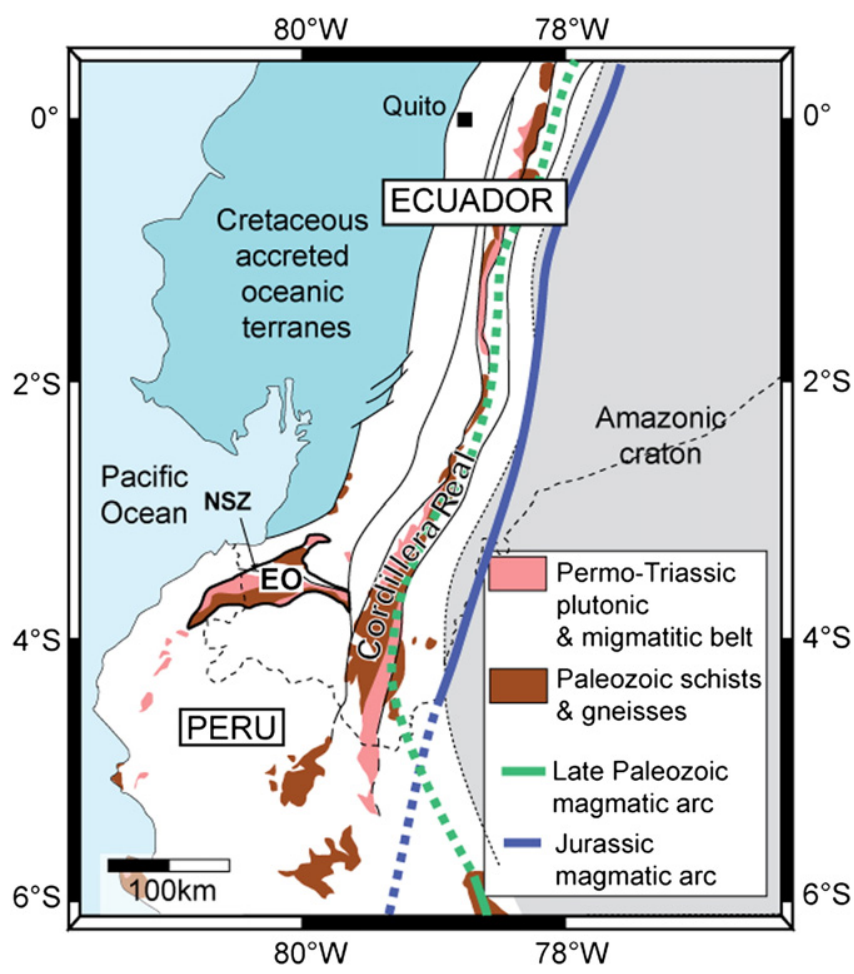

Fig. 1. Simplified geological map of Ecuador and northern Peru modified after Chew et al. (2007) showing the location of the El Oro metamorphic complex. EO, El Oro; NSZ, Naranjo Shear Zone. Continuous line: documented magmatic arc position, dashed line: inferred magmatic arc position.

by S-type granitoids (Marcabeli and El Prado plutonic rocks), juxtaposed with amphibolitic metagabbros (Piedras unit) and blueschist facies metabasalts (Arenillas-Panupalí unit) (Fig. 2). Because of the subvertical structures, this complex has been interpreted either as a shear zone active during the Triassic (Aspden et al., 1995), or as a remnant of a forearc zone tilted during a major tectonic event in the Late Triassic (Gabriele, 2002). However, little is known about the geological structures of the continental sequence and its relationships with the Piedras metagabbroic unit and the Arenillas-Panupali blueschist unit.

Here, we focus our study on the HT-LP Triassic rocks of the El Oro metamorphic complex (Fig. 2). Our aims are to: (1) characterize the deformation of those units; (2) estimate the peak metamorphic $P-T$ conditions; (3) age of migmatization; and (4) propose a model for the HT-LP gradient and the crustal anatexis associated with underplating of $H P-L T$ rocks. Here we present the results obtained by combining field work, textural observations, mineralogical identification, geothermobarometry and geochronological studies. The analytical methods are presented in the Appendix A.

\section{Geological setting and previous studies}

In SE Ecuador various metamorphic terranes of both continental and oceanic affinity form the El Oro metamorphic complex (Aspden et al., 1995; Feininger, 1978). This complex is bounded to the south by the Cretaceous volcano-sedimentary sequence of the Celica-Lancones basin (Jaillard et al., 1996, 1999), to the NE by Tertiary volcanic deposits and to the NW by Cenozoic, recent sedimentary deposits (Fig. 2). This complex is characterized by its forearc position and by discordant E-W striking structures, within the NNE striking Andean orogenic belt (Fig. 1). The Late Paleozoic subduction related magmatic arc is known to occur within the Cordillera Central of Colombia (Vinasco et al., 2006), in NW Peru (Mišković, et al., 2009), and a Jurassic magmatic arc is known in Colombia and Ecuador, lying in the Subandean Zone
(Jaillard et al., 2000). Consequently, since at least Carboniferous times, the El Oro metamorphic complex has been located in a forearc position relative to Pacific subduction zone (Fig. 1).

Three tectono-metamorphic groups are distinguished for the $\mathrm{El}$ Oro metamorphic complex:

(1) The Biron Complex, North of the La Palma-Guayabo Shear Zone (Fig. 2), consists of metasediments, migmatitic paragneisses, granitoids, metadiorites and amphibolites with a N-MORB-type geochemical affinity (Gabriele, 2002). Ar-Ar radiometric datings on biotite in migmatites and in metadiorites yielded cooling ages of $75.5 \pm 2.3 \mathrm{Ma}$ and $78.4 \pm 0.5 \mathrm{Ma}$, respectively. $\mathrm{Pb}-\mathrm{Pb}$ dating on monazites yielded ages of $78 \pm 1 \mathrm{Ma}$ and $82 \pm 1 \mathrm{Ma}$, and three $\mathrm{U}-\mathrm{Pb}$ zircon analyses plot on a reverse discordia with a lower intercept at 200 $\pm 30 \mathrm{Ma}$ (Noble et al., 1997). Noble et al. (1997) interpreted the lower intercept at $200 \pm 30 \mathrm{Ma}$ as the age of crystallization of the granitoid, and attributed the younger monazite ages to a later episode of deformation and metamorphism.

(2) South of the La Palma-Guayabo shear zone (Fig. 2), the Raspas complex (Feininger, 1980) consists of an ophiolitic massif, the El Toro metaperidotitic unit, and the Raspas eclogitic unit (Gabriele et al., 2003; John et al., 2010). The Lu-Hf ages of John et al. (2010) from the Raspas complex indicate that the ophiolite underwent prograde HP metamorphism at around $130 \mathrm{Ma}$. Radiometric dating yielded an age of $127-123 \mathrm{Ma}(\mathrm{Ar} / \mathrm{Ar}$ on phengite), which was interpreted as the age of underplating of the Raspas eclogitic complex beneath the Ecuadorian margin (Feininger and Silberman, 1982; Gabriele, 2002; John et al., 2010).

(3) The El Oro paired metamorphic belt is located between the Raspas complex and the Cretaceous Celica-Lancones Basin (Figs 1 \& 2) and consists of late Paleozoic sediments (Martínez, 1970) metamorphosed during the Triassic (Aspden et al., 1995), juxtaposed with the Piedras gabbroic unit (Aspden et al., 1992b) and with the Arenillas-Panupalí blueschist unit metamorphosed in the Triassic (Gabriele, 2002). From south to north (Fig. 2), the continental sequence is composed of the El Tigre and La Victoria low-to-high-grade metapelitic units, intruded by the Marcabeli S-type granitoid at $227 \pm 0.5 \mathrm{Ma}$ (U-Pb on zircon, Noble et al., 1997) and of the La Bocana migmatitic unit dated at $219 \pm 22 \mathrm{Ma}$ (Sm/Nd whole-rock/garnet isochron; Aspden et al., 1995). In the Piedras metagabbroic unit, U-Pb ages on zircon are $221 \pm 17 \mathrm{Ma}$ (Noble et al., 1997) and Ar-Ar ages on amphibole yielded an age of $226 \pm 1.8 \mathrm{Ma}$ (Gabriele, 2002). Geochemical studies indicate a MORB-type affinity for the Piedras gabbroic unit (Aspden et al., 1995; Bosch et al., 2002; Gabriele, 2002). Both the Piedras and the Arenillas-Panupalí units were retrogressed under greenschist-facies conditions (Gabriele, 2002).

The El Tigre unit dips approximately to the north $\left(50-60^{\circ}\right)$, and is composed of turbidites (Aspden et al., 1992a). On its southern boundary the El Tigre unit is unconformably overlain by the Cretaceous sediments of the Celica-Lancones basin. In the north, the appearance of chlorite and biotite (Fig. 2) marks a gradational transition zone between the low metamorphic grade El Tigre unit and the moderate- to high-grade La Victoria unit. The La Victoria unit comprises a sequence of metapelites and metapsammites similar to that of the El Tigre unit. To the north, the La Victoria unit is typically composed of biotite \pm muscovite \pm fibrolite, albite and quartz with andalusite porphyroblasts. The Marcabeli S-type granitoid into the La Victoria unit is an elongated E-W trending laccolithic body. This pluton principally consists of medium-grained biotite \pm muscovite granodiorites, with hornblende-rich xenoliths (Aspden et al., 1995). The contact between the La Victoria unit and the La Bocana unit has been interpreted as a syn- to late-magmatic dextral shear zone (Aspden et al., 1995), which is coeval with sillimanite crystallization (Feininger, 1978). These shear zones show a sub-vertical foliation. North of Marcabeli, Feininger (1978) mapped a folded contact between the La Victoria and the La Bocana unit (Fig. 2), with a lens of the La 


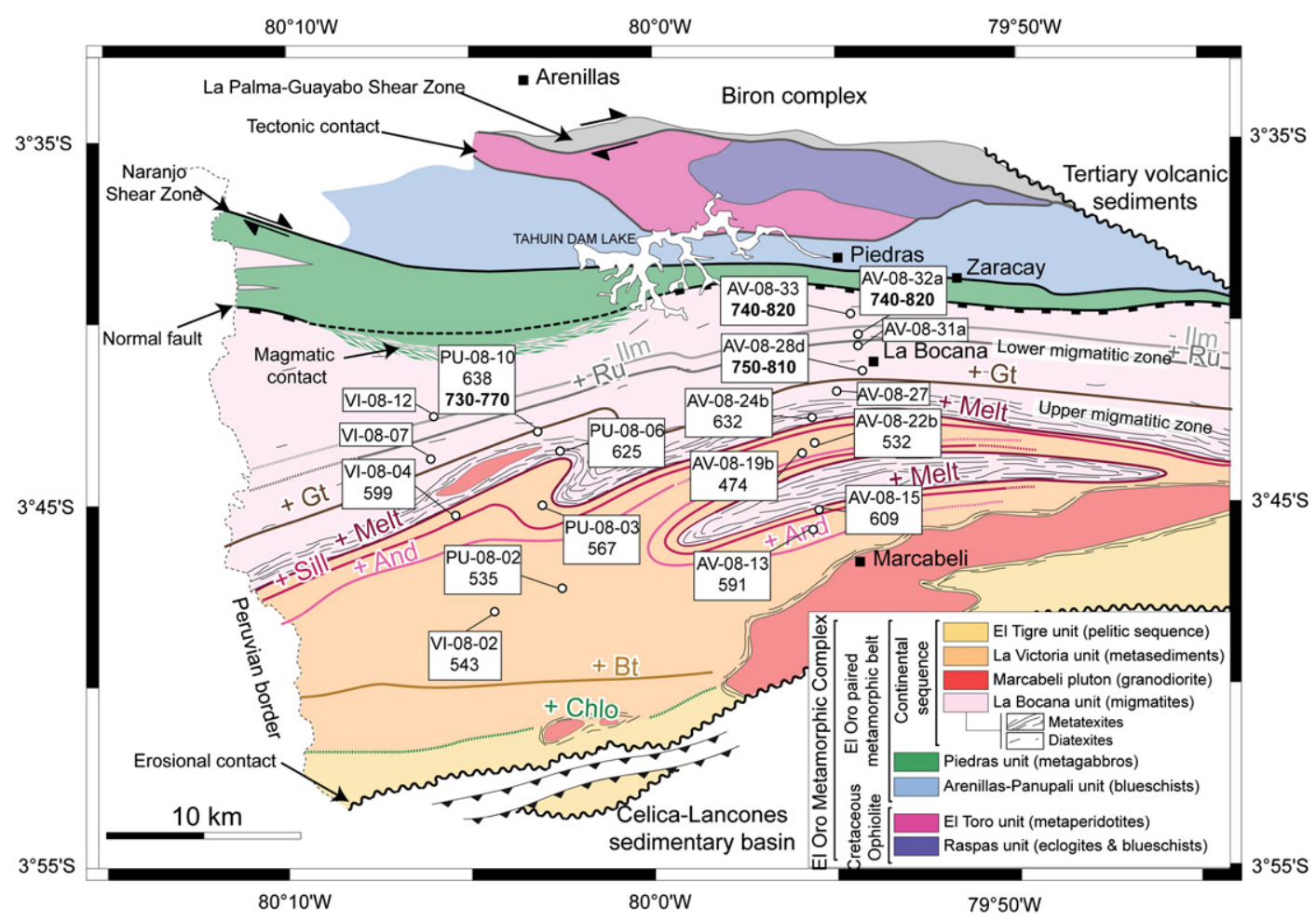

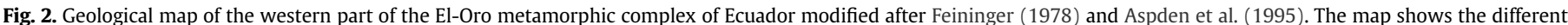

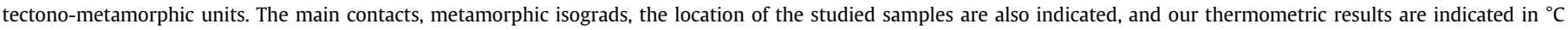

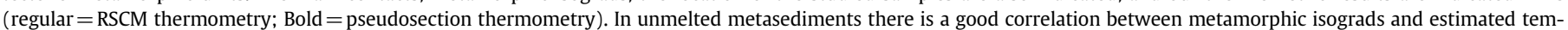

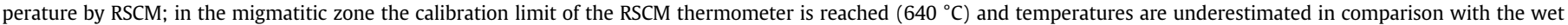
solidus $\left(\sim 650{ }^{\circ} \mathrm{C}\right)$ and calculated pseudosection temperatures in garnet-bearing migmatites $\left(\sim 750\right.$ to $\left.820{ }^{\circ} \mathrm{C}\right)$.

Bocana unit cropping out within the metasediments of the La Victoria unit. Moreover, the metamorphic isograds follow the structure, implying that folding was post-metamorphic. The La Bocana unit (Fig. 2) has been described by Aspden et al. (1995) at its type locality as predominantly composed of garnet-bearing granitoid and lesser amounts of metatexites. North of the La Bocana unit, the contact with the Piedras unit (Fig. 2) is recognized as tectonic (Gabriele, 2002). However, amphibolite xenoliths at the base of the La Bocana unit and granitic bodies within the Piedras unit suggest that the contact was originally intrusive (Aspden et al., 1995). The Piedras dips to the south $\left(70-90^{\circ}\right)$, and is 3 to $5 \mathrm{~km}$ thick. This unit is mainly composed of amphibolites retrogressed under greenschist-facies conditions, and shows variable textures, massive to gneissic, fine to coarse grained (Gabriele, 2002). It can be traced from the Peruvian border for about $60 \mathrm{~km}$ to the east (Aspden and Litherland, 1992). The contact zone between the Piedras unit and the Arenillas-Panupalí unit is defined by the Naranjo shear zone (Gabriele, 2002). The Arenillas-Panupalí unit roughly strikes E-W and presents a sub-vertical foliation. It forms a $40 \mathrm{~km}$ long, 0.5 to $5 \mathrm{~km}$ wide belt. This unit is composed of metabasalts and metasediments retrogressed under greenschist-facies, relict blueschist-facies assemblage. The peak $P-T$ conditions of this unit are estimated by Gabriele (2002) at $\sim 9 \mathrm{kbar}$ and $300{ }^{\circ} \mathrm{C}$ from garnet + glaucophane + titanite.

The El Oro metamorphic complex was first interpreted as a continental terrane accreted to the Andean margin during Late Jurassic to Early Cretaceous times (Mourier et al., 1988). Aspden et al. (1995) interpreted the El Oro metamorphic complex as a tectonic mélange formed in a Jurassic accretionary prism, preserving in the southern part a HT metamorphosed and migmatized unit of Late Triassic age. On the basis of the presence of garnet and glaucophane, Aspden et al. (1995) considered the Arenillas-Panupalí blueschist unit as part of the Late Jurassic-Early Cretaceous Raspas ophiolitic complex (Aspden and Litherland, 1992; Aspden et al., 1992a). Additionally,
Aspden et al. (1995) suggested that the emplacement of the gabbroic Piedras unit into the active shear zone provided the heat source for crustal anatexis and formation of the S-type Marcabeli granitoid in $H T-L P$ conditions. More recently, based on the MORB-like geochemical affinity and radiometric ages on amphibole of $225.3 \pm 1.7 \mathrm{Ma}$, Gabriele (2002) described the Arenillas-Panupalí unit as a new tectono-metamorphic blueschist unit located between the Raspas complex to the north, and the Piedras unit to the south.

Based on the geochemical MORB-type affinity and on the radiometric age of $226 \pm 1.8 \mathrm{Ma}$ of the Piedras unit, Gabriele (2002) interpreted this unit as having originated during a pre-Jurassic subduction period, subsequently accreted to the continental margin. However, according to Noble et al. (1994), the zircons of the Piedras unit are of magmatic origin, and hence the age of $221 \pm 17$ Ma is considered to be the crystallization age. Although the Piedras unit shows a MORB-type signature, it is predominantly composed of amphibolites, with relict gabbroic textures, and no pillow basalts or sediments have been observed, thus favoring a plutonic origin. The continental sequence exhibits a northward increase in metamorphic temperature conditions (Feininger, 1978). Gabriele (2002) suggested this increase in thermal conditions from low-grade metasediments (El Tigre and La Victoria units) to high-grade migmatites (La Bocana unit) was related to the thermal gradient of a crustal sequence, and the present-day geometry with sub-vertical foliation resulted from the tilting of the entire sequence during a major tectonic event in the Late Triassic ( 220 Ma).

\section{Field relationships and migmatite morphology}

From south to north, we focused our study on two subparallel cross-sections starting from the Cretaceous contact of the CelicaLancones basin to the eclogitic unit of Raspas. The location of the 
studied samples is shown in Fig. 2. We observed the same metamorphic evolution from south to north in the La Victoria unit as Feininger (1978) and Aspden et al. (1995). Kinematic indicators (Fig. 3a, b) largely exhibit dextral transtensive apparent movement. The transition from the La Victoria to the La Bocana units is marked by the appearance of in situ melting and numerous metatexites. The southernmost evidence of partial melting in the La Victoria is represented by leucocratic veins emplaced within the unmelted metasediments (Fig. 4e).

Along the eastern cross-section, the migmatitic succession of the La Bocana unit out crops $3 \mathrm{~km}$ south of La Bocana village (Fig. 2). This succession can be followed along the Río Piedras with almost no interruption from low-melt fraction metatexites to the south, to the high-melt fraction mesocratic diatexites to the north (Figs. 2 \& 4). Foliation is subvertical or strongly dipping to the south. The migmatitic succession starts with the appearance of small pockets of in situ melts that are only generated in fertile layers (Fig. 4, zone 2). As the fraction of melt increases in metatexitic migmatites, the sparse pockets of melts become connected (Fig. 4, zone 3). A psammite-pelite original layering, similar to the La Victoria, is still present and shows complex geometries due to contrasting rheological behavior controlled by the different amounts of melt or melt network. Leucocratic and melanocratic parts within pelitic layers are often folded together and
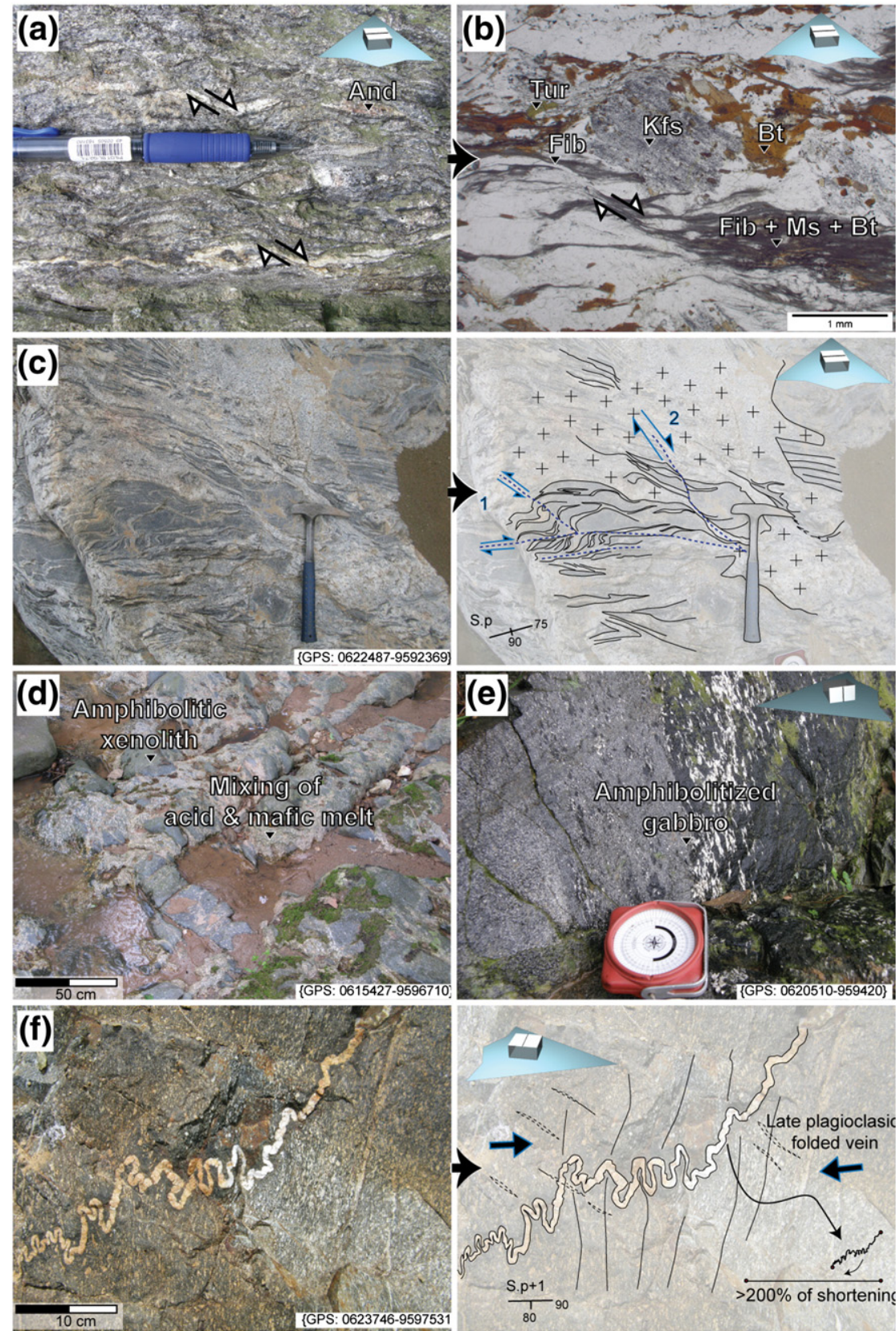

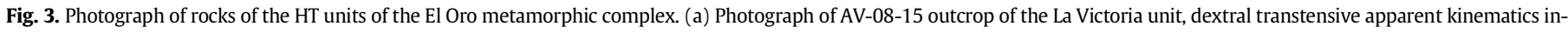

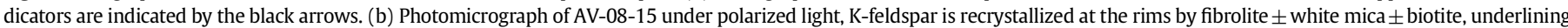

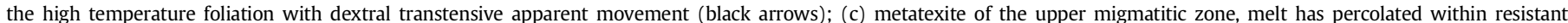

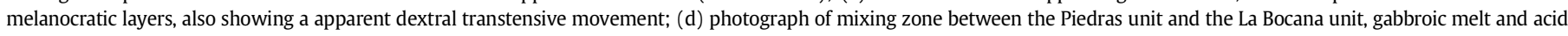

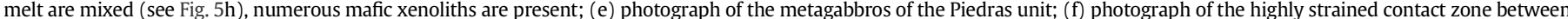

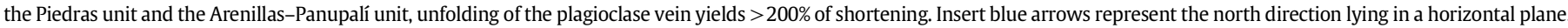

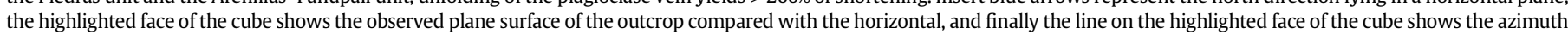
of the foliation. 

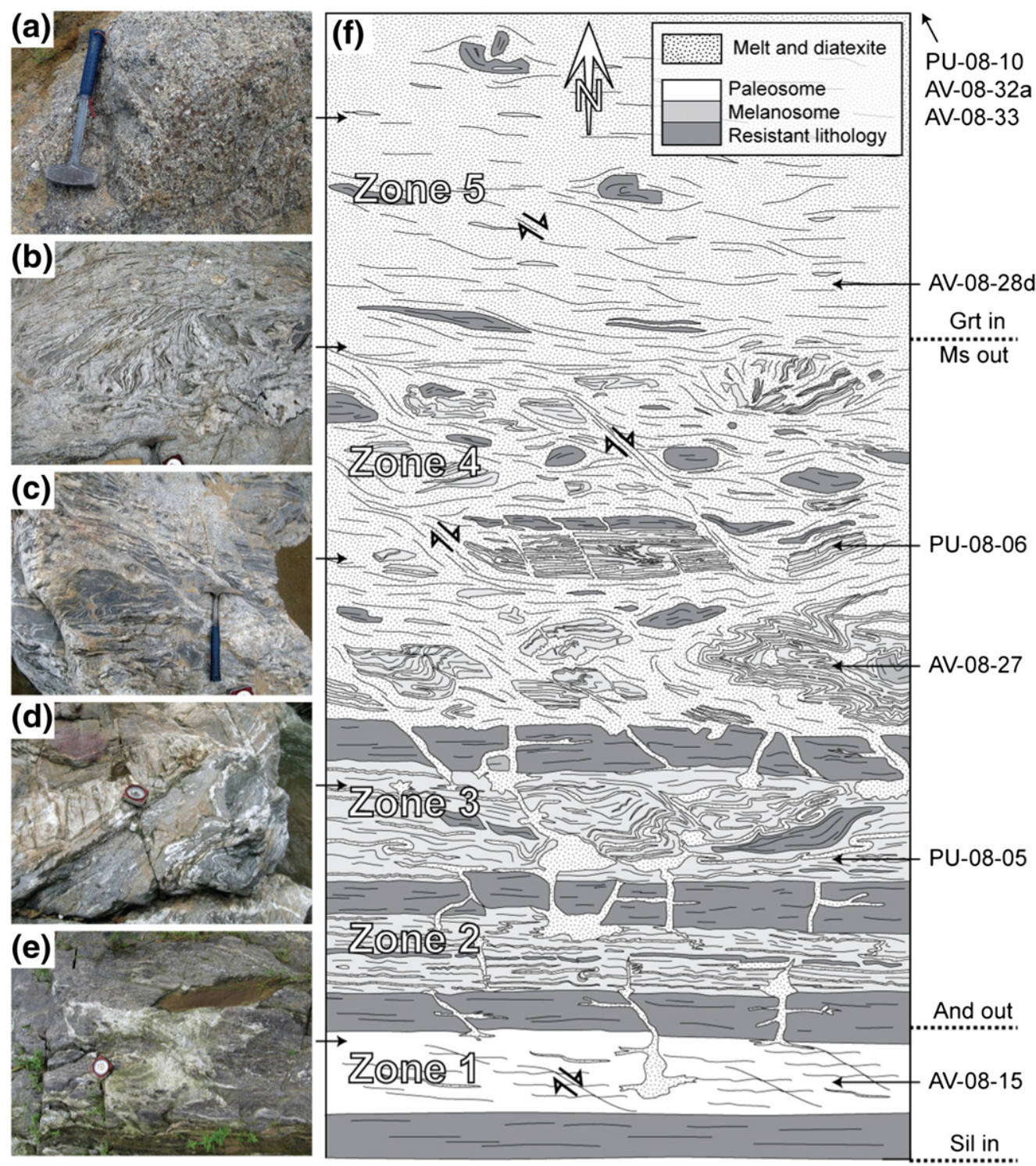

Fig. 4. Migmatitic "log" of the upper part of the La Bocana unit. (a-e), photographs of outcrops in relation to their structural level in the migmatitic log; (f) schematic log representing the upper migmatitic section for a $4 \mathrm{~km}$ thick; internal structures are purposely magnified and the different generations of leucosomes are not distinguished; zone 1 : first appearance of melt with a very low fraction of in situ melting; zone 2: melting occurs through white-mica dehydration in the pelitic rich layers producing metatexites and melt fraction is inferior to $25 \%$; between the zones 1 to 2,2 to 3 and 3 to 4, psammitic layers poor in micas, are not, or are weakly affected by in situ melting; zone 3: melt fraction increases, but the metatexitic texture is still dominant and several generations of leucosomes can be observed; they are either folded with residual layers or crosscutting the former ones; as the melt fraction increases, metatexites becomes diatexites of zone 4 with large rafts of resistant bodies (quartz rich); zone 5: garnet appears and the volume of resistant lithologies decreases. The migmatites acquire homogeneous diatexitic magma like rheology and no syn-migmatitic preferred orientation can be seen, at least at the macroscopic scale.

crosscut by leucocratic veins. Psammitic layers are less fertile (lower white mica content) and more competent, and show dilatant structures (Figs 3c \& 4c), which allow leaching and facilitate circulation of melt throughout the crustal pile. Close to the garnet zone, melting affects the whole metasedimentary pile (Fig. 4, zone 4 ) forming diatexites with large amounts of rafts of resistant lithologies (quartz-rich unmelted bodies). Further north, garnet crystallizes and the volume of residual (biotite-rich) lithologies decreases signficantly. At the top of this $7 \mathrm{~km}$ thick zone, melt is pervasive and early structures are erased. Resulting textures are mesocratic to melanocratic diatexites and have variable proportions of biotite and garnet (Fig. 4a). Within the garnet-bearing migmatitic layer, quartzite and other resistant bodies are dissolved in the melt toward the north, and are almost absent near the contact with the Piedras unit. Apparent kinematic indicators largely exhibit dextral transtension and roughly $\mathrm{N}-\mathrm{S}$ dilatant structures. $\mathrm{N}-\mathrm{S}$ structures of escaping melt are observed in competent layers (Fig. 4, zone 2 and 3) and show a southward direction of melt percolation (initially upward, taking into account subsequent tilting; Gabriele, 2002). Close to Piedras, the contact between the La Bocana and the Piedras units is tectonic and exhibits normal low-grade ductile faulting with top-to-the-south movement. In the western part, this contact zone exhibits mafic xenoliths (Fig. 2) and variably mixed dioritic magmas a short distance (up to $100 \mathrm{~m}$ ) into the La Bocana unit. Resulting textures are produced by mingling and/or mixing of acidic and mafic melts (Fig. 3d). The Piedras unit as described by Aspden et al. (1995) is made of saussuritized metagabbros (now amphibolites, Fig. 3e). In addition, we found ultramafic lenses with relicts of olivine along the eastern cross-section, south of the Piedras locality. Farther north, the contact between the Piedras and Arenillas-Panupali units (Naranjo Shear Zone) is diffused and highly deformed with dextral transpressive shear sense under low-grade metamorphic conditions (Fig. 3f). In addition, we observed a limited amount of serpentininite (up to 10\%) within the Arenillas-Panupalí unit. 


\section{Petrography and mineral assemblages}

Mineral assemblages of the continental sequence are described from the low-grade metasediments of the La Victoria unit to the south, to the high-grade molten metasediments of the La Bocana unit to the north. The location of studied samples is shown in Fig. 2 and characteristic mineral assemblages are presented in Table 1.

\subsection{La Victoria metapelites}

Near the boundary between the El Tigre and La Victoria units, the metapelite is composed of chlorite + biotite + quartz + plagioclase, thus defining a chlorite-biotite zone. Farther north, in the biotite zone (Fig. 2), the characteristic mineral assemblage is biotite + white mica + quartz + K-feldspar + plagioclase. In the psammitic layers, the mineral assemblage is dominated by quartz, with subordinate biotite and white mica. In the andalusite zone (Fig. 2) (AV-08-19b, Table 1), the typical mineral assemblage is biotite + white mica + andalusite + quartz + K-feldspar + plagioclase. Farther north, andalusite is progressively replaced by fibrolite (Feininger, 1978). Although cordierite is widely reported in this unit by Aspden et al. (1995), this mineral was not observed in examined samples. In the narrow andalusite-fribolite zone, the characteristic assemblage is andalusite + sillimanite + biotite + whitemica + quartz + K-feldspar + plagioclase. Weakly strained chiastolitic andalusite occurs as large porphyroblasts up to $5 \mathrm{~cm}$. In rare samples andalusite is statically replaced by kyanite on its outer edge (AV-08-15). On the rim of these andalusite/kyanite porphyroblasts, kyanite is replaced by biotite and fibers of sillimanite (fibrolite) (Fig. 5a \& b). The fibrolite defines the main foliation (Fig. 5b), and deflects the older fabric with apparent dextral transtensive movement.

The andalusite fribolite assemblage is transitional to the anatectic zone. Textural relationships observed in AV-08-15 sample show that the crystallization sequence was: andalusite, kyanite, and sillimanite. This suggests a clock-wise $P-T$ path that looped around the $\mathrm{Al}_{2} \mathrm{SiO}_{5}$ triple point (Whitney, 2002).

\subsection{La Bocana migmatites}

On the basis of the mineralogical assemblage, we distinguished two sub-units in the La Bocana unit. Near the contact with the unmelted metasediments of the La Victoria unit, the upper migmatitic zone is characterized by metatexites without garnet (Fig. 4, zones 1 to 4 ). The lower migmatitic zone is characterized by garnet-bearing diatexites (Fig. 4, zones 5). On the eastern cross-section, this zone begins near the locality of La Bocana and extends northward to the Piedras unit.

In the upper migmatitic zone (Fig. 4, zone 4), the melanosome characteristic mineral assemblage is biotite + sillimanite + quartz +
K-feldspar + plagioclase \pm retrograde white-mica. Sillimanite occurs as prismatic aggregate of minerals associated with lath-like biotite and $\mathrm{K}$-feldspar. Rare spinel is present as small inclusions of hercynite within large prismatic sillimanite (Fig. 5d). Cesare (1994) showed that inclusion of herycnite in prismatic sillimanite formed after breakdown of staurolite at $585-655^{\circ} \mathrm{C}$. Therefore, hercynite in the upper La Bocana migmatites likely represents relicts of prograde metamorphism at subsolidus conditions. Fibrolite occurs on the outer rim of the prismatic sillimanite often surrounded by late white-mica. Leucocratic layers exhibit larger grain size, and are dominated by quartz, plagioclase and K-feldspar. Biotite occurs as well crystallized, or interstitial, grains. Late white-mica occurs as late interstitial crystals at grain boundaries of plagioclase and K-feldspar. Vermicular intergrowth of feldspar and quartz at K-feldspar grain boundary are widely observed (Fig. 6a). Symplectic intergrowth of muscovite and quartz are also a common feature in this zone (Fig. 6a). These two last migmatitic microstructures are compatible with crystallization from melt. In this upper migmatite zone, garnet, orthopyroxene and cordierite are absent from the samples examined in this study. Biotite is present in every sample and its composition does not exhibits significant variation compared to the biotite of the La Victoria unit (Fig. 7d). Thus, natural observations are consistent with melting of the metasedimentary rocks in this zone within the stability field of the biotite at a temperature close to the solidus between 640 and $700{ }^{\circ} \mathrm{C}$ (Patiño-Douce and Harris, 1998; Vielzeuf and Holloway, 1988). Melting reactions principally involved white mica breakdown. Two major melting reactions are thought to occur in this zone, either by fluid-present, or fluid-absent white-mica dehydration melting (Patiño-Douce and Harris, 1998; Thompson and Tracy, 1979):

white mica + plagioclase + quartz $+\mathrm{H}_{2} \mathrm{O}=$ melt + sillimanite + biotite

And

white mica + plagioclase + quartz $=$ melt + sillimanite + K-feldspar + biotite

In the lower migmatitic zone, the most significant microstructure associated with partial melting is the segregation of felsic material surrounding peritectic products, erasing pre-melting structures and leading to the formation of relatively homogeneous mesocratic to melanocratic migmatites (Fig. 4a). Neither preferred orientation, nor migmatitic foliation can be recognized, at least at the macroscopic scale. The characteristic mineral assemblage is biotite + garnet + sillimanite + quartz + K-feldspar + plagioclase. Garnet contains inclusions of biotite, prismatic sillimanite and plagioclase, ilmenite and/or rutile. In the north of the lower migmatitic zone, modal percent of garnet

Table 1

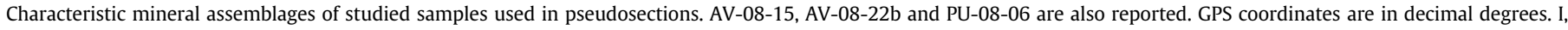
inherited mineral; P, Peak thermal mineral; R, retrograde mineral. Mineral abbreviations used in figures and tables are from Kretz (1983).

\begin{tabular}{|c|c|c|c|c|c|c|c|c|c|c|c|c|c|c|}
\hline \multirow[b]{2}{*}{ Sample } & \multicolumn{4}{|c|}{ Localisation } & \multicolumn{10}{|c|}{ Mineralogy } \\
\hline & Long & Lat & Unit & Lithology & $\mathrm{Kfs}$ & And & Ky & Sil & $\mathrm{Gt}$ & $\mathrm{Bt}$ & Ms & Chl & $\mathrm{Ilm}$ & $\mathrm{Ru}$ \\
\hline AV-08-19b & -79.927 & -3.755 & La Victoria & Metapelite & $\mathrm{P}$ & I & - & - & - & $\mathrm{I}+\mathrm{P}$ & $\mathrm{I}+\mathrm{P}$ & $\mathrm{P}$ & I & - \\
\hline AV-08-22b & -79.921 & -3.714 & La Victoria & Metapsammite & $\mathrm{P}$ & - & - & - & - & $\mathrm{I}+\mathrm{P}$ & $\mathrm{I}+\mathrm{P}$ & $\mathrm{P}$ & I & - \\
\hline AV-08-13 & -79.925 & -3.747 & La Victoria & Metapsammite & $\mathrm{P}$ & $\mathrm{P}$ & - & - & - & $\mathrm{I}+\mathrm{P}$ & $\mathrm{I}+\mathrm{P}$ & - & I & - \\
\hline VI-08-04 & -80.080 & -3.755 & La Victoria & Metapsammite & $\mathrm{P}$ & - & - & $\mathrm{P}$ & - & $\mathrm{I}+\mathrm{P}$ & $\mathrm{I}+\mathrm{P}$ & - & I & - \\
\hline AV-08-15 & -79.925 & -3.739 & La Victoria & Metapelite & $\mathrm{P}$ & I & I & $\mathrm{P}$ & - & $\mathrm{I}+\mathrm{P}$ & $\mathrm{I}+\mathrm{P}$ & - & I & - \\
\hline PU-08-06 & -80.045 & -3.727 & La Bocana & Sil migmatite & $\mathrm{P}$ & - & - & $\mathrm{P}$ & - & $\mathrm{I}+\mathrm{P}$ & $\mathrm{R}$ & - & I & - \\
\hline AV-08-24b & -79.927 & -3.709 & La Bocana & Sil migmatite & $\mathrm{P}$ & - & - & $\mathrm{P}$ & - & $\mathrm{I}+\mathrm{P}+\mathrm{R}$ & $\mathrm{R}$ & - & I & - \\
\hline AV-08-27 & -79.921 & -3.702 & La Bocana & Sil migmatite & $\mathrm{P}$ & - & - & $\mathrm{P}$ & - & $\mathrm{I}+\mathrm{P}+\mathrm{R}$ & $\mathrm{R}$ & - & $\mathrm{P}$ & I \\
\hline AV-08-28d & -79.904 & -3.678 & La Bocana & Gt migmatite & $\mathrm{P}+\mathrm{R}$ & - & - & $P+R$ & $\mathrm{P}$ & $\mathrm{P}+\mathrm{R}$ & $\mathrm{R}$ & $\mathrm{R}$ & $\mathrm{P}$ & I \\
\hline AV-08-32a & -79.906 & -3.667 & La Bocana & Gt migmatite & $\mathrm{P}+\mathrm{R}$ & - & - & $P+R$ & $\mathrm{P}$ & $\mathrm{P}+\mathrm{R}$ & $\mathrm{R}$ & $\mathrm{R}$ & $\mathrm{P}$ & I \\
\hline AV-08-33 & -79.909 & -3.664 & La Bocana & Gt migmatite & $P+R$ & - & - & $P+R$ & $\mathrm{P}$ & $P+R$ & $\mathrm{R}$ & $\mathrm{R}$ & - & I \\
\hline PU-08-10 & -80.055 & -3.716 & La Bocana & Gt migmatite & $P+R$ & - & - & $P+R$ & $\mathrm{P}$ & $\mathrm{P}+\mathrm{R}$ & $\mathrm{R}$ & - & I & - \\
\hline
\end{tabular}



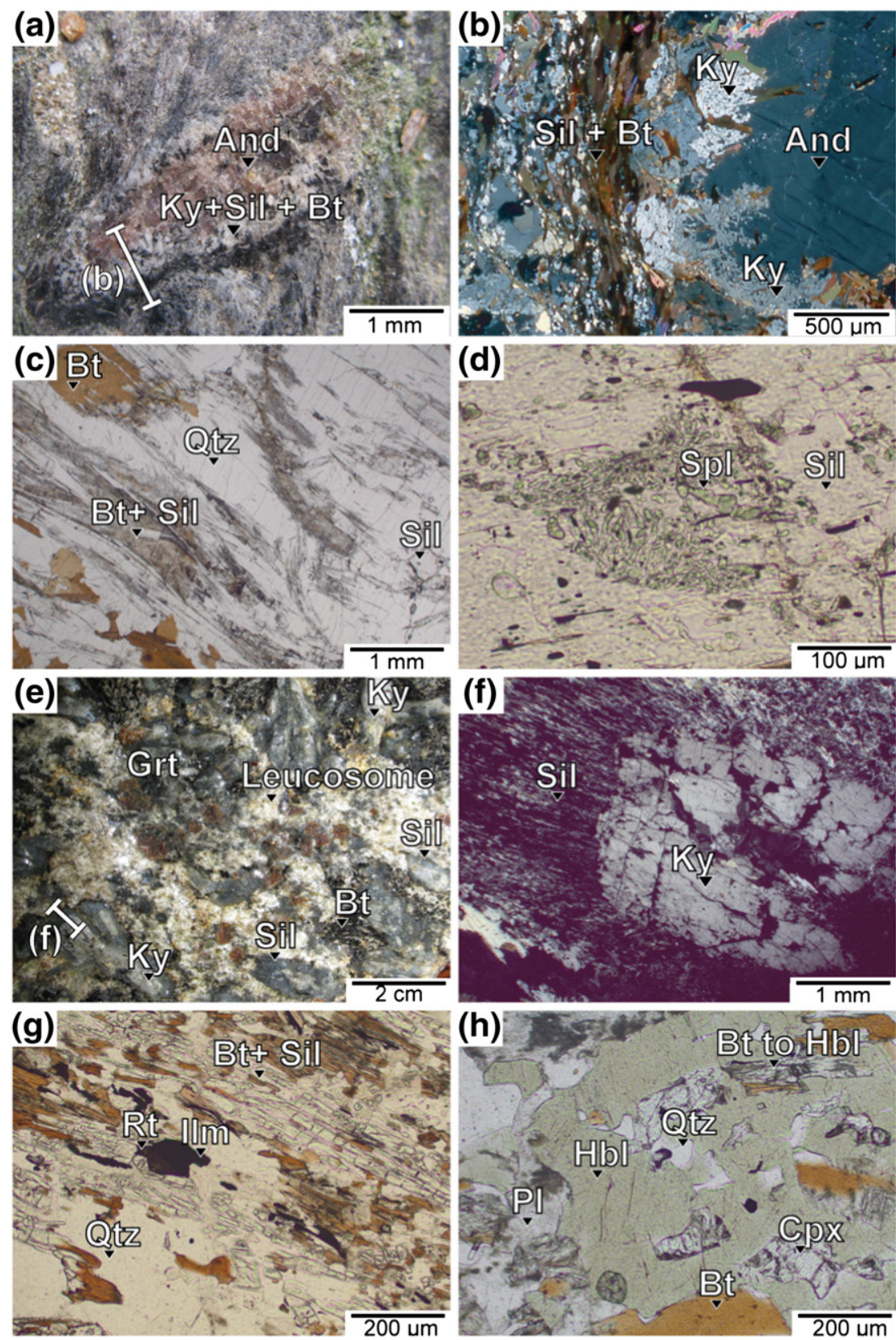

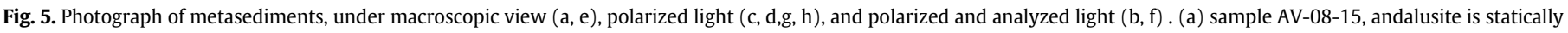

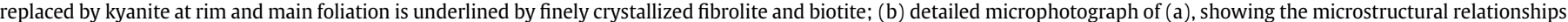

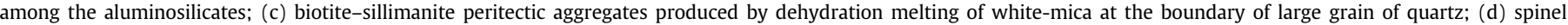

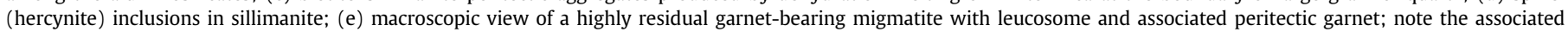

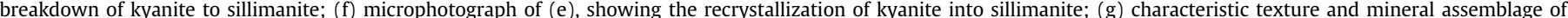

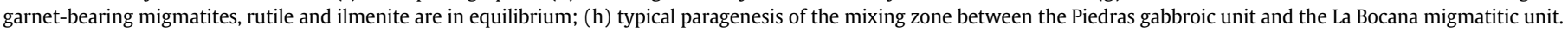

increases, garnet becomes skeletal and elongated, and the sillimanite content decreases. Biotite occurs, either as elongated lath-like aggregate together with sillimanite, or as interstitial grains within quartz + plagioclase + K-feldspar rich layers (Fig. $5 \mathrm{~g}$ ). While garnet is well preserved in many samples, with only limited breakdown into biotite at rims, K-feldspar belonging to residual aggregates (schlieren) appears to be largely recrystallized and/or breakdown. Fig. 6e \& f show penetrative breakdown of K-feldspar in symplectic intergrowth of biotite + sillimanite + quartz + plagiocase indicating that these phases were crystallizing from the melt during cooling (Spear et al., 1999). In the lower migmatitic zone white-mica is almost absent. However, in a few samples such as AV-08-35, white mica overgrows plagioclase and K-feldspar, forming a common low-temperature alteration product
(Fig. 6b). The appearance of garnet, absence of white mica and decreasing sillimanite and biotite content toward higher metamorphic grade implies incongruent melting produced by biotite dehydration (PatiñoDouce and Jonhston, 1991; Vielzeuf and Holloway, 1988):

biotite + alumino-silicate + quartz $=$ melt + garnet + K-feldspar

and

biotite + plagioclase + quartz $\pm \mathrm{H}_{2} \mathrm{O}=$ melt + garnet $\pm \mathrm{K}$-feldspar

Whether reactions (3) and (4) produce K-feldspar as peritectic phase is dependent on the activity of $\mathrm{H}_{2} \mathrm{O}$. In the La Victoria and the 

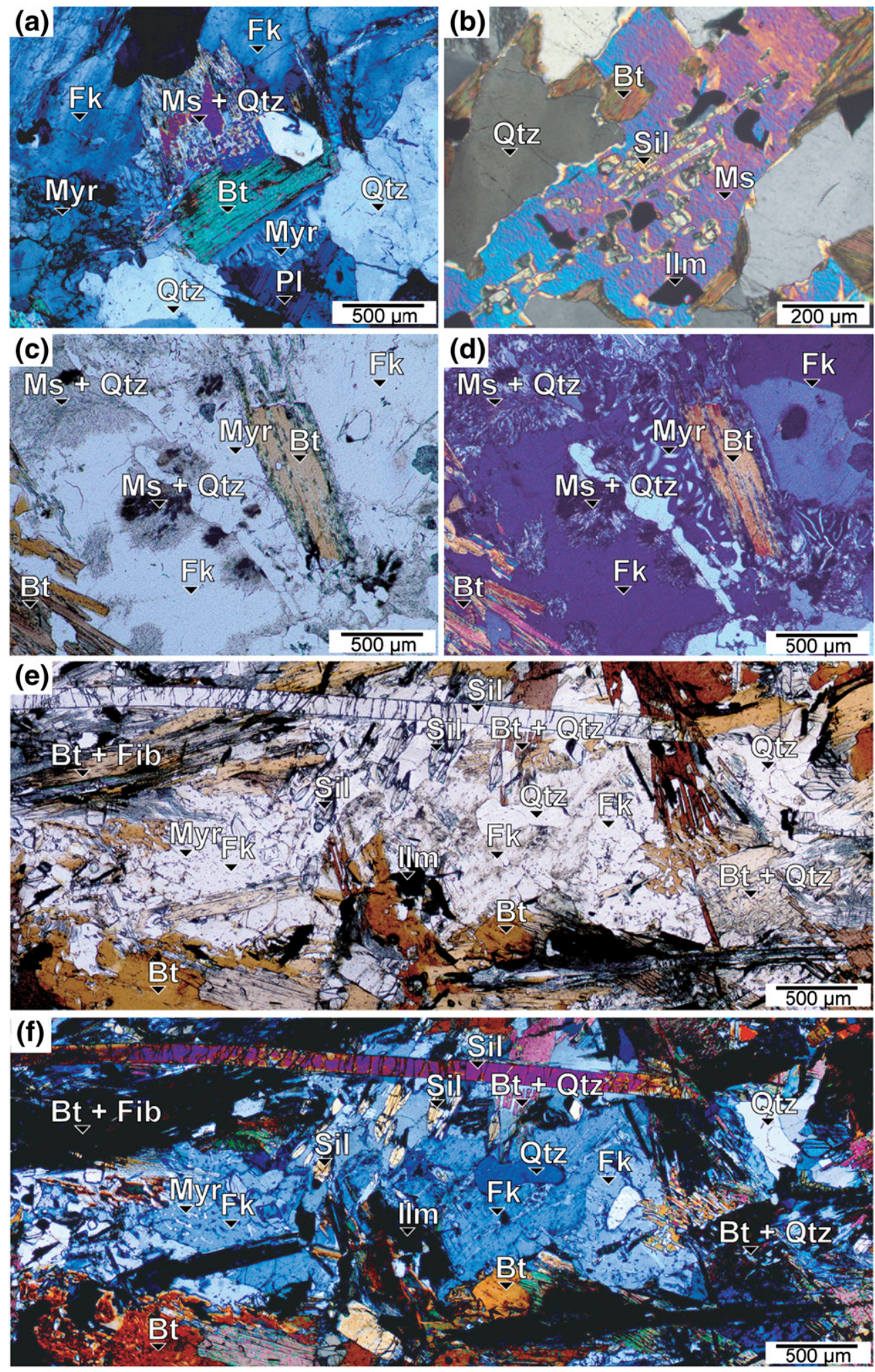

Fig. 6. Microphotograph of partially molten metasediments under polarized and analyzed light (a, b, d, f) and polarized light (c, e). (a) sample PU-08-06, interaction between residual melt and K-feldspar forming myrmekite and muscovite + quartz symplectite; (b) late crystallization of muscovite in AV-08-35o garnet-bearing sample; (c, d) AV-08-28d garnet-bearing sample, retrograde interaction between residual melt and K-feldspar forming myrmekite and likely contributed to the penetrative saussuritization of the K-feldspar in muscovite + quartz; (e, f) PU-08-10 garnet-bearing sample, retrograde interaction between residual melt and a large crystal of K-feldspar. The former K-feldspar grains are largely broken down by the formation of myrmekite, crystallization of quartz + biotite symplectite and late crystallization of crosscutting prismatic sillimanite crystals

La Bocana units graphite is omnipresent in examined samples. Connolly and Cesare (1993) showed that C-O-H fluid produced by the equilibration of $\mathrm{H}_{2} \mathrm{O}$ and excess graphite must maintain the atomic $\mathrm{H} / \mathrm{O}$ ratio of water, 2:1. This precludes water saturated conditions during partial melting and thus favors reactions (2) and (3) of dehydration melting in the Upper and the Lower La Bocana units, respectively. 
Along the western cross-section, at the transition zone between the upper and lower migmatitic zone, garnet is associated in highly residual layers. Relict kyanite is replaced by pluricentimetric sillimanite (Fig. 5e \& f). For metapelitic lithologies ilmenite and rutile are the two main Ti-bearing minerals as ilmenite and rutile are stable at low and high pressure, respectively. Ilmenite and/or rutile present in the studied samples exhibits a South to North modal variability (Table 1, Fig. 2). Whereas in the la Victoria unit only ilmenite has been observed, in the
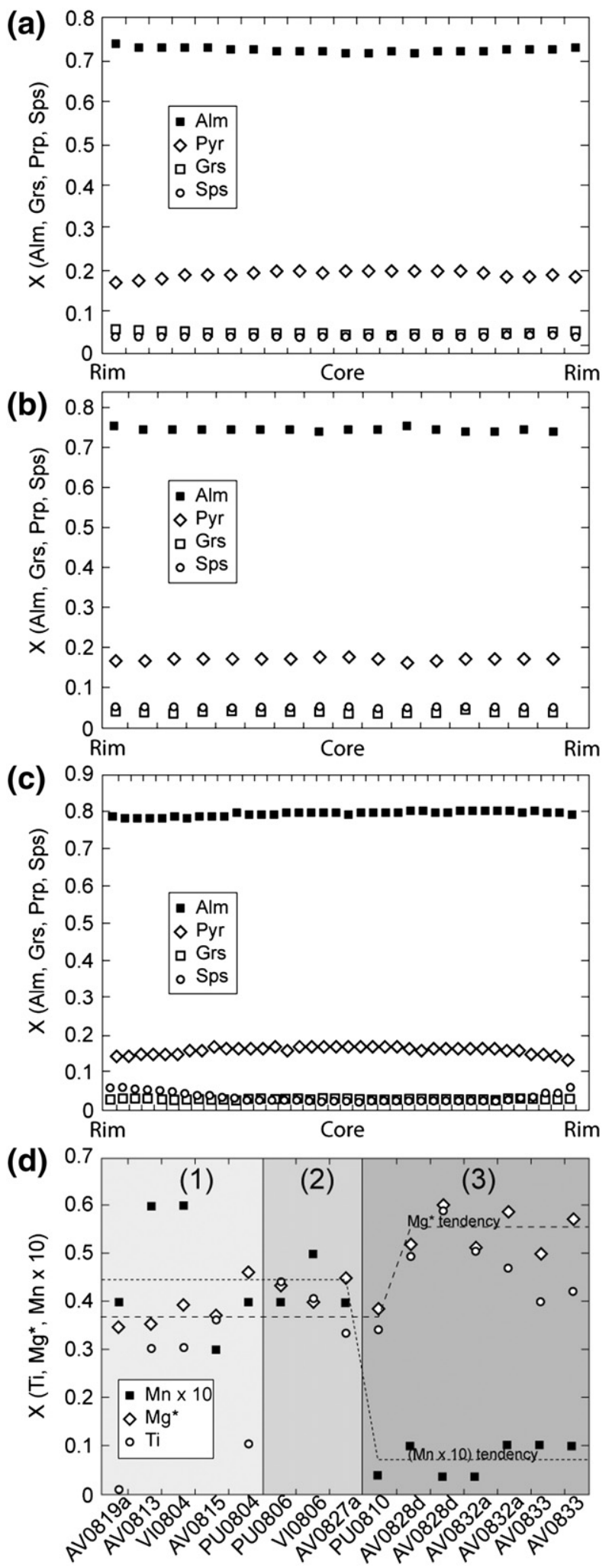

lower migmatitic zone, we observe layers containing both ilmenite and rutile in equilibrium (Fig. $5 \mathrm{~g}$ ). North of this area only rutile is observed (see Fig. 2). This mineral succession, from ilmenite in the La Victoria unit to rutile in the La Bocana unit, suggests an increase in pressure conditions toward the north. In sample AV-08-28d, ilmenite is present in the matrix with relict rutile cores, whereas rutile is not observed as inclusions in garnet. Crystallization of sillimanite from kyanite and of ilmenite from rutile shows that the continental sequence recorded heating and/or decompression, which is consistent with the clock-wise $P-T$ path around the $\mathrm{Al}_{2} \mathrm{O}_{3}$ triple point observed in sample AV-08-15. Furthermore, the lack of rutile inclusions in garnet in sample AV-08$28 \mathrm{~d}$ indicates that decompression started before garnet crystallization.

\subsection{Piedras amphibolites}

In the Piedras unit, the characteristic mineral assemblage is hornblende + plagioclase + titanite + epidote + actinolite \pm quartz \pm clinopyroxene. Clinopyroxene is rare and its rims are always replaced by hornblende (Aspden et al., 1995). Plagioclase is widely saussuritized, and epidote and actinolite represent retrogression under greenschist facies conditions. Near the locality of Piedras, ultramafic lenses (Fig. 2) with characteristic mineral assemblage of olivine + serpentine + magnetite \pm clinopyroxene characteristic mineral assemblage were identified. In the western cross-section, in the contact zone with the La Bocana migmatites, mixing of acid and basic magmas (Fig. 3d) produced a mineral assemblage composed of hornblende + clinopyroxene + biotite + quartz + plagioclase (Fig. $5 \mathrm{~h}$ ).

\subsection{Arenillas-Panupalí blueschists}

The Arenillas-Panupalí unit is mainly represented by metabasalts metamorphosed under blueschist facies conditions, which underwent an intense greenschist facies overprint. Pressure peak-metamorphic conditions are characterized by the garnet + glaucophane + titanite assemblage (Gabriele, 2002). The greenschist overprint is documented by crystallization of fine-grained albite, chlorite and epidote, and by glaucophane breaking down to barroisite and actinolite (Gabriele, 2002).

\section{Mineral chemistry}

Representative analyses of garnet are presented in Table 2. Almost all garnets are found in the lower migmatitic zone, and are interpreted as peritectic phases (no sub-solidus garnet). Garnet exhibits little or no chemical variations from core to rim (Fig. $7 \mathrm{a}-\mathrm{c}$ ). $X_{\mathrm{Alm}}$ content from sample-to-sample (Table 1 ) ranges from 0.70 to $0.80, X_{\operatorname{Prp}}$ content from 0.13 to $0.20, X_{\mathrm{Grs}}$ from 0.02 to 0.06 and $X_{\mathrm{Sps}}$ from 0.02 to 0.06 . $X_{\mathrm{Alm}}$ and $X_{\mathrm{Prp}}$ variations between different samples reflect their differences in $\mathrm{MgO} /(\mathrm{MgO}+\mathrm{FeO})$ bulk composition (Table 7). Representative analyses of biotite are presented in Table 3. In metasediments, the $X_{\mathrm{Mg}}$ in biotite ranges from 0.33 to 0.46 in metapelites, and from 0.48 to 0.62 in garnet-bearing migmatites (Fig. $7 \mathrm{~d}$ ). Titanium content per formulae unit (p.f.u.) varies from 0.10 to 0.44 for unmolten metapelites,

Fig. 7. Garnet and biotite chemical composition of the El Oro metamorphic complex El Oro metamorphic complex. (a, b, c) Microprobe analysis across garnet crystal of AV-08-28d (a), AV-08-32a (b) and PU-08-10 (c) samples. Most of the end-members exhibit relatively flat pattern for all samples, excepted for (b) and (c) where $X_{p y r}$ and $X_{s p s}$ are respectively, slightly depleted and enriched at rim; (d) $X_{\left(\mathrm{Ti}, \mathrm{Mg}^{*}, \mathrm{Mn} \times 10\right)}$ of biotite of various listed samples across the El Oro metamorphic complex. (1) La Victoria metasediments, (2) upper the La Bocana metatexites, (3) lower the La Bocana garnet-bearing migmatites. $\mathrm{Mg}^{*}=\mathrm{Mg} /(\mathrm{Fe}+\mathrm{Mg})$. The $\mathrm{Mg}^{*}$ tendency exhibits an increase from 0.36 in the zone (1) and (2) to 0.55 in the zone (3) where partial melting occurred under biotite dehydration melting. $X_{M n}$ (Mn p.f.u. ${ }^{*} 10$, see Table 3 ) drops from 0.45 in zones ( 1 ) and ( 2 ) down to $<0.1$ in zone (3). This coincides with the condition of partial melting of biotite. Storage of $\mathrm{Mn}$ in biotite in lower metamorphic grades (zone (1) and (2)) can account for the absence of garnet whereas pseudosections stabilize garnet when $\mathrm{MnO}$ is used. $X_{T i}$ (p.f.u., see Table 3 ) is of 0.3 to 0.4 in zone (1) and (2) and becomes $>0.4$ in zone (3). 
Table 2

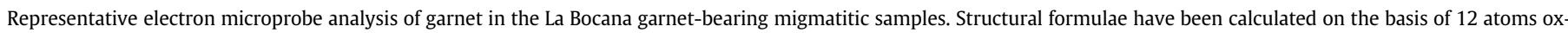
ygen; calculated end members shown in the table are used to calculate the P-T conditions in pseudosections. La Vic., La Victoria, U. B., Upper La Bocana, L. B., Lower La Bocana.

\begin{tabular}{|c|c|c|c|c|c|c|c|}
\hline Sample & PU0803 & PU0810 & & AV0829 & AV0832a & AV0828d & AV0833 \\
\hline Unit & La Vic. & L. B. & & L. B. & L. B. & L. B. & L. B. \\
\hline Position & Core & Core & Rim & Core & Core & Core & Core \\
\hline $\mathrm{SiO}_{2}$ & 36 & 37.71 & 37.93 & 36.62 & 37.08 & 37.9 & 37.23 \\
\hline $\mathrm{TiO}_{2}$ & 0 & 0.08 & 0 & 0.02 & 0.05 & 0.09 & 0.03 \\
\hline $\mathrm{Al}_{2} \mathrm{O}_{3}$ & 20.3 & 20.77 & 20.79 & 21.26 & 21.72 & 21.34 & 20.972 \\
\hline $\mathrm{FeO}$ & 24.4 & 35.52 & 34.89 & 34.13 & 33.2 & 32.78 & 33.49 \\
\hline $\mathrm{MnO}$ & 12.4 & 0.87 & 2.48 & 2.4 & 1.77 & 1.36 & 2.29 \\
\hline $\mathrm{MgO}$ & 3 & 4.04 & 3.4 & 3.99 & 4.64 & 4.77 & 4.44 \\
\hline $\mathrm{CaO}$ & 3.5 & 0.95 & 0.81 & 1.35 & 1.58 & 1.77 & 1.46 \\
\hline Total & 99.6 & 99.95 & 100.31 & 99.77 & 100.04 & 100.01 & 99.9 \\
\hline \multicolumn{8}{|c|}{ Structural formulae (12 anhydrous oxygen basis) } \\
\hline $\mathrm{Si}$ & 2.88 & 2.77 & 2.78 & 2.71 & 2.71 & 2.76 & 2.74 \\
\hline $\mathrm{Ti}$ & 0 & 0 & 0 & 0 & 0 & 0 & 0 \\
\hline Al & 1.92 & 1.8 & 1.8 & 1.85 & 1.87 & 1.83 & 1.82 \\
\hline $\mathrm{Fe}$ & 1.64 & 2.18 & 2.14 & 2.11 & 2.03 & 1.994 & 2.06 \\
\hline Mn & 0.85 & 0.05 & 0.15 & 0.15 & 0.11 & 0.08 & 0.14 \\
\hline $\mathrm{Mg}$ & 0.36 & 0.44 & 0.37 & 0.44 & 0.51 & 0.52 & 0.49 \\
\hline $\mathrm{Ca}$ & 0.3 & 0.07 & 0.06 & 0.11 & 0.12 & 0.14 & 0.11 \\
\hline Total & 7.94 & 7.33 & 7.32 & 7.37 & 7.35 & 7.32 & 7.35 \\
\hline \multicolumn{8}{|c|}{ Endmembers (mol\%) } \\
\hline Pyrope & 11.34 & 16.07 & 13.62 & 15.67 & 18.27 & 18.93 & 17.36 \\
\hline Almandine & 52.16 & 79.25 & 78.4 & 75.17 & 73.31 & 72.96 & 73.45 \\
\hline Grossular & 9.56 & 2.72 & 2.33 & 3.81 & 4.47 & 5.05 & 4.1 \\
\hline Spessartine & 26.94 & 1.97 & 5.64 & 5.35 & 3.96 & 3.07 & 5.09 \\
\hline $\mathrm{Mg} /(\mathrm{Fe}+\mathrm{Mg})$ & 0.18 & 0.17 & 0.15 & 0.17 & 0.20 & 0.21 & 0.19 \\
\hline
\end{tabular}

to a range of 0.40 to 0.60 for migmatites (Fig. $7 \mathrm{~d}$ ). $\mathrm{X}_{\mathrm{Mnx} 10}$ varies from 0.30 to 0.60 for metapelites and low grade migmatites (without garnet), whereas in garnet-bearing migmatites, $\mathrm{X}_{\mathrm{Mnx} 10}$ varies from 0.05 to 0.10 . This drop in $\mathrm{X}_{\mathrm{Mnx} 10}$ correlates with the apparition of garnet and with the ongoing biotite dehydration melting.

Titanium content and $X_{\mathrm{Mg}}$ increase in biotite is compatible with biotite progressive incongruent melting (Patiño-Douce and Harris, 1998). White mica is present in metapelites as a prograde and peak- $T$ phase, whereas in the garnet-bearing migmatites, white mica occurs as a retrograde phase that results from saussuritization of feldspar or late back reaction from melt (Fig. 6c-f). In metapelites and migmatites, white mica shows no significant compositional differences and is muscovite-rich $\left(X_{\mathrm{Mu}}>0.80\right)$ with $X_{\mathrm{Cel}}$ accounting for the rest (Table 4). Silica content (p.f.u.) ranges from 3.00 to 3.05. In metapelite, plagioclase has high $X_{\mathrm{Ab}}$, between 0.75 and 0.85 . In high grade metapelites close to the anatectic zone, plagioclase is zoned and exhibits a slight enrichment in $X_{\mathrm{Ab}}$ from core to rim ( 0.77 to 0.83 ). In migmatites, plagioclase composition is more variable and $X_{\mathrm{Ab}}$ ranges from 0.60 to 1.00 . Plagioclase commonly exhibits symplectite textures of micron-scale white mica + plagioclase with lower $X_{\mathrm{An}}$.

\section{Thermobarometry}

Thermobarometry has been performed combining three independent approaches: the Raman Spectroscopy on Carbonaceous Matter thermometry (RSCM see Appendix A), pseudosections and Fe-Mg exchange thermometry.

\subsection{RSCM thermometry and garnet-biotite thermometry}

As carbonaceous material is present in all metasediments of the continental sequence, we used RSCM thermometry, which is based on the degree of organization of carbonaceous material. This method gives estimates on the maximal temperature undergone by the rocks for thermal conditions between $330{ }^{\circ} \mathrm{C}$ and $640{ }^{\circ} \mathrm{C} \pm 50{ }^{\circ} \mathrm{C}$ (Beyssac et al., 2002, 2004). RSCM is also applied on middle to relatively high grade metamorphic rocks up to the complete graphitization at $\sim 640{ }^{\circ} \mathrm{C}$ (Robert et al., 2010). Table 6 shows the RSCM thermometry results. $\mathrm{T}_{\text {max }}$ estimated with the RSCM method, range from 475 to $640{ }^{\circ} \mathrm{C}$, with a general increase in temperature from south to north.

PU-08-03 is the only unmolten metasediment in which small grains of garnet are present. Garnet-biotite thermometery on this sample yields temperatures of $560 \pm 50{ }^{\circ} \mathrm{C}$ and $570 \pm 50{ }^{\circ} \mathrm{C}$, with the calibrations of Ferry and Spear (1978) and Perchuk and Lavrent'eva (1983), respectively. $T_{\max }$ with RSCM thermometry on the same sample gives $567 \pm 50{ }^{\circ} \mathrm{C}$ (Table 6 ), which is in very good agreement with the garnet-biotite temperature. For high grade migmatitic samples, inclusions of graphite were rare and often located on the surface of the host minerals. Few analyses were carried out on these samples (3-5 spectra per sample), but the obtained spectra are of good quality $\left(1 \sigma<8{ }^{\circ} \mathrm{C}\right) . T_{\max }$ obtained in migmatites reach the graphitization $T$ and are indicative of minimum temperature. We observe no discrepancy between the peak $T$ mineralogical assemblages and the RSCM thermometry.

\subsection{Pseudosections}

$P-T$ and $T-X$ pseudosections have been calculated (1) to precise metamorphic $P-T$ conditions and more particularly conditions of partial melting, and (2) to determine the type of prograde melting reactions. Phase relations have been modeled in the Ti(Mn)NKFMASH system using Perple_X'07 software (Connolly, 2005) and using the internally consistent thermodynamic database of Holland and Powell (1998). Bulk rock composition, solution models and end-member phases considered in the modeling are listed in Tables 7 and 8, respectively. Although the $\mathrm{TiO}_{2}$ component is a minor component, it has been included to the model in order to take into account the rutile/ilmenite transition observed along the cross-section (Fig. 2, Table 1). MnO is taken into account for garnet-bearing migmatite in order to better estimate the end-member composition of garnet. In unmelted metasediments, the only $\mathrm{MnO}$-bearing phases are biotite and ilmenite as garnet which typically contains $\mathrm{MnO}$ has not been observed. Therefore $\mathrm{MnO}$ is not taken into consideration for the calculation of pseudosections of unmelted metasediments as $\mathrm{MnO}$ as little effect on the stability field of biotite. Water content in the $P-T$ 


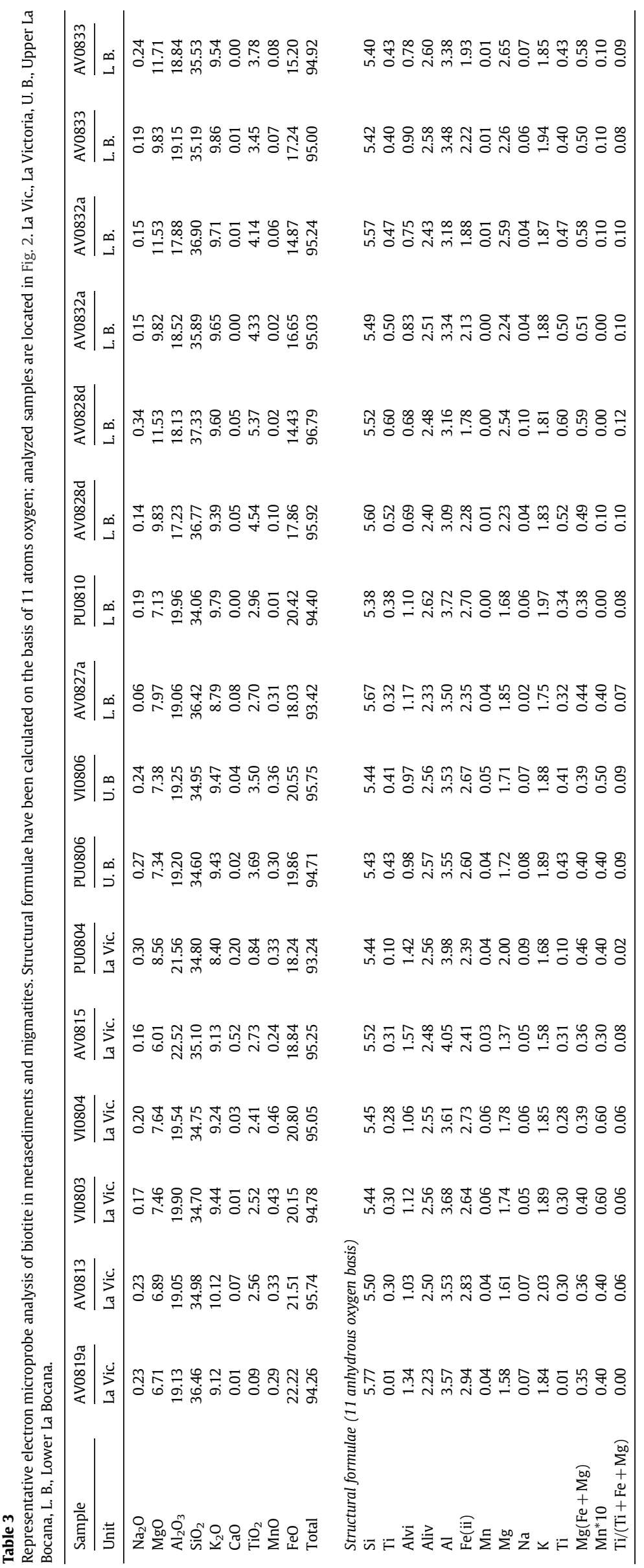


Table 4

Representative electron microprobe analysis of muscovite in metasediments and migmatites. Structural formulae have been calculated on the basis of 11 atoms oxygen; analyzed samples are located in Fig. 2. La Vic., La Victoria, U. B., Upper La Bocana, L. B., Lower La Bocana.

\begin{tabular}{|c|c|c|c|c|c|c|}
\hline Sample & AV0819a & AV0813 & AV0815 & VI0803 & PU0806 & AV08350 \\
\hline Unit & La Vic. & La Vic. & La Vic. & La Vic. & U. B. & L. B. \\
\hline $\mathrm{Na}_{2} \mathrm{O}$ & 0.84 & 0.30 & 0.59 & 0.55 & 0.63 & 0.32 \\
\hline MgO & 0.38 & 0.75 & 0.49 & 0.49 & 0.62 & 0.89 \\
\hline $\mathrm{Al}_{2} \mathrm{O}_{3}$ & 36.78 & 34.03 & 36.69 & 36.80 & 36.57 & 35.76 \\
\hline $\mathrm{SiO}_{2}$ & 48.61 & 46.57 & 45.08 & 45.17 & 45.50 & 49.10 \\
\hline $\mathrm{K} 2 \mathrm{O}$ & 8.97 & 10.27 & 10.58 & 9.91 & 10.77 & 8.40 \\
\hline $\mathrm{CaO}$ & 0.00 & 0.15 & 0.00 & 0.03 & 0.00 & 0.00 \\
\hline $\mathrm{TiO}_{2}$ & 0.10 & 0.94 & 0.66 & 0.63 & 0.00 & 1.28 \\
\hline $\mathrm{MnO}$ & 0.00 & 0.02 & 0.00 & 0.01 & 1.00 & 0.03 \\
\hline $\mathrm{FeO}$ & 0.94 & 1.34 & 0.90 & 1.05 & 1.08 & 1.20 \\
\hline $\mathrm{Zr}_{2} \mathrm{O}_{3}$ & 0.03 & 0.00 & 0.00 & 0.00 & 0.00 & 0.00 \\
\hline Total & 96.64 & 94.38 & 95.01 & 94.64 & 96.17 & 96.99 \\
\hline \multicolumn{7}{|c|}{ Structural formulae (11 anhydrous oxygen basis) } \\
\hline $\mathrm{Si}$ & 3.14 & 3.13 & 3.01 & 3.02 & 3.02 & 3.16 \\
\hline $\mathrm{Ti}$ & 0.01 & 0.05 & 0.04 & 0.03 & 0.00 & 0.06 \\
\hline Alvi & 1.94 & 1.83 & 1.90 & 1.91 & 1.88 & 1.87 \\
\hline Aliv & 0.86 & 0.87 & 0.99 & 0.99 & 0.98 & 0.85 \\
\hline $\mathrm{Al}$ & 2.80 & 2.70 & 2.89 & 2.90 & 2.86 & 2.71 \\
\hline $\mathrm{Fe}(\mathrm{ii})$ & 0.05 & 0.08 & 0.05 & 0.06 & 0.06 & 0.07 \\
\hline $\mathrm{Mn}$ & 0.00 & 0.00 & 0.00 & 0.00 & 0.06 & 0.00 \\
\hline $\mathrm{Mg}$ & 0.04 & 0.08 & 0.05 & 0.05 & 0.06 & 0.09 \\
\hline $\mathrm{Na}$ & 0.11 & 0.04 & 0.08 & 0.07 & 0.08 & 0.04 \\
\hline K & 0.74 & 0.88 & 0.90 & 0.85 & 0.91 & 0.69 \\
\hline \multicolumn{7}{|c|}{ Endmembers (mol\%) } \\
\hline Pyrophilite & 15.5 & 8.0 & 2.5 & 8.5 & 1.0 & 27.0 \\
\hline Céladonite & 1.0 & 22.5 & 10.0 & 5.0 & 1.0 & 10.5 \\
\hline Muscovite & 81.0 & 72.0 & 87.5 & 84.5 & 92.5 & 61.0 \\
\hline Phlogopite & 2.5 & -2.5 & 0.0 & 2.0 & 5.5 & 1.5 \\
\hline
\end{tabular}

pseudosections is kept constant for the entire range of $P-T$ conditions. This water content was estimated for each sample by calculating $T-X_{\mathrm{H} 2 \mathrm{O}}$ pseudosection and $P-X_{H 2 O}$ pseudosections. The chosen water content
Table 6

RSCM thermometry results of studied samples. Analytical uncertainties on the estimation of temperature are quoted at $1 \sigma$ while the calibration error for each sample on the determination of absolute temperature is of $\pm 50{ }^{\circ} \mathrm{C}$.

\begin{tabular}{llllll}
\hline Sample & No analysis & $\mathrm{R} 2$ & $\mathrm{Std}$ & $\mathrm{T}{ }^{\circ} \mathrm{C}$ Beyssac et al., (2002) & $1 \sigma$ \\
\hline AV0813 & 9 & 0.11 & 0.03 & 591 & 4.73 \\
AV0815 & 7 & 0.07 & 0.01 & 609 & 2.47 \\
AV0819b & 10 & 0.38 & 0.05 & 474 & 6.93 \\
AV0822b & 8 & 0.24 & 0.04 & 532 & 5.79 \\
AV0824b & $\mathbf{4}$ & 0.02 & 0.01 & 632 & 1.09 \\
PU0802 & 9 & 0.24 & 0.05 & 535 & 7.96 \\
PU0803 & 8 & 0.17 & 0.04 & 567 & 6.06 \\
PU0806 & $\mathbf{3}$ & 0.04 & 0.01 & 625 & 1.65 \\
PU0811 & $\mathbf{3}$ & 0.01 & 0.01 & 638 & 2.03 \\
VI0802 & 6 & 0.22 & 0.04 & 543 & 6.60 \\
VI0804 & $\mathbf{5}$ & 0.09 & 0.03 & 599 & 5.77 \\
\hline
\end{tabular}

corresponds to the minimum amount of water necessary to saturate the sub-solidus assemblage just below the solidus with no free water. In these conditions $\mathrm{C}-\mathrm{O}-\mathrm{H}$ fluids in the graphitic saturated system of the metasediments of the La Victoria and the La Bocana units have not been modeled.

\subsubsection{Metasediments}

We selected one metapsammite (AV-08-13) and one metapelite (AV-08-15) belonging to a different structural level of the La Victoria unit in order to constrain the evolution of the $P-T$ conditions within the metasedimentary sequence. Sample AV-08-15 and sample AV-08-13 are located in the narrow andalusite-fibrolite zone (Fig. 2).

In the metasediments of the La Victoria unit, the association of biotite + sillimanite \pm white mica defines the foliation (Fig. 5b). In sample AV-08-15, the observed mineral assemblage, $X_{\mathrm{Mg}}$ of biotite (0.36), $\mathrm{X}_{\mathrm{Ab}}(0.79)$ shows that the $P-T_{\max }$ conditions lie in the field of biotite + plagioclase $+\mathrm{K}$-feldspar + muscovite + sillimanite + quartz (Fig. 8). This is consistent with RSCM thermometry of $609 \pm 50{ }^{\circ} \mathrm{C}$. Thus, associated extensional microstructures observed in sample

Table 5

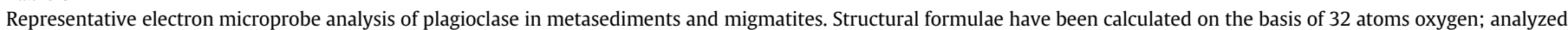
samples are located in Fig. 2. La Vic., La Victoria, U. B., Upper La Bocana, L. B., Lower La Bocana.

\begin{tabular}{|c|c|c|c|c|c|c|c|c|c|}
\hline Sample & AV-08-13 & AV-08-15 & PU0806 & AV0828d & AV0828d & PU0810 & PU0810 & AV0832a & AV0833 \\
\hline Unit & La Vic. & La Vic. & U. B. & L. B. & L. B. & L. B. & L. B. & L. B. & L. B. \\
\hline Position & Core & Core & Core & Schlieren & Leucosome & Schlieren & Leucosome & Schlieren & Schlieren \\
\hline $\mathrm{Na}_{2} \mathrm{O}$ & 9.47 & 9.34 & 9.52 & 6.98 & 7.90 & 9.08 & 10.20 & 8.23 & 7.92 \\
\hline MgO & 0.00 & 0.00 & 0.00 & 0.00 & 0.00 & 0.00 & 0.00 & 0.00 & 0.00 \\
\hline $\mathrm{Al}_{2} \mathrm{O}_{3}$ & 22.68 & 22.93 & 24.00 & 25.78 & 25.13 & 22.53 & 21.14 & 25.21 & 25.12 \\
\hline $\mathrm{SiO}_{2}$ & 63.36 & 63.62 & 62.71 & 59.39 & 60.27 & 63.90 & 65.72 & 60.42 & 59.87 \\
\hline $\mathrm{K} 2 \mathrm{O}$ & 0.12 & 0.23 & 0.14 & 0.51 & 0.22 & 0.22 & 0.33 & 0.22 & 0.24 \\
\hline $\mathrm{CaO}$ & 3.40 & 4.14 & 4.04 & 7.38 & 6.71 & 4.51 & 2.64 & 6.64 & 6.74 \\
\hline $\mathrm{TiO}_{2}$ & 0.00 & 0.02 & 0.02 & 0.02 & 0.00 & 0.04 & 0.02 & 0.02 & 0.05 \\
\hline $\mathrm{MnO}$ & 0.00 & 0.04 & 0.03 & 0.04 & 0.01 & 0.00 & 0.00 & 0.03 & 0.01 \\
\hline $\mathrm{FeO}$ & 0.00 & 0.04 & 0.21 & 0.24 & 0.04 & 0.05 & 0.00 & 0.03 & 0.03 \\
\hline $\mathrm{Zr}_{2} \mathrm{O}_{3}$ & 0.00 & 0.02 & 0.00 & 0.00 & 0.00 & 0.00 & 0.00 & 0.00 & 0.00 \\
\hline Total & 99.04 & 100.38 & 100.66 & 100.35 & 100.28 & 100.33 & 100.06 & 100.80 & 99.96 \\
\hline \multicolumn{10}{|c|}{ Numbers of ions on the basis of 320} \\
\hline $\mathrm{Si}$ & 11.38 & 11.42 & 11.26 & 10.66 & 10.82 & 11.47 & 11.80 & 10.85 & 10.75 \\
\hline Al & 4.80 & 4.85 & 5.08 & 5.46 & 5.32 & 4.77 & 4.47 & 5.33 & 5.31 \\
\hline $\mathrm{Fe}(\mathrm{ii})$ & 0.00 & 0.01 & 0.03 & 0.04 & 0.01 & 0.01 & 0.00 & 0.00 & 0.00 \\
\hline $\mathrm{Ca}$ & 0.65 & 0.80 & 0.78 & 1.42 & 1.29 & 0.87 & 0.51 & 1.28 & 1.30 \\
\hline $\mathrm{Na}$ & 3.30 & 3.25 & 3.31 & 2.43 & 2.75 & 3.16 & 3.55 & 2.86 & 2.76 \\
\hline K & 0.03 & 0.05 & 0.03 & 0.12 & 0.05 & 0.05 & 0.08 & 0.05 & 0.05 \\
\hline $\mathrm{Ba}$ & 0.00 & 0.00 & 0.00 & 0.00 & 0.00 & 0.00 & 0.00 & 0.00 & 0.00 \\
\hline Total & 20.15 & 20.38 & 20.49 & 20.12 & 20.23 & 20.33 & 20.41 & 20.38 & 20.17 \\
\hline \multicolumn{10}{|c|}{ Endmembers (mol\%) } \\
\hline Anorthite & 16.46 & 19.42 & 18.84 & 35.77 & 31.54 & 21.27 & 12.27 & 30.45 & 31.56 \\
\hline Albite & 82.85 & 79.29 & 80.37 & 61.27 & 67.21 & 77.52 & 85.89 & 68.35 & 67.11 \\
\hline Orthose & 0.69 & 1.29 & 0.79 & 2.97 & 1.26 & 1.22 & 1.84 & 1.21 & 1.33 \\
\hline
\end{tabular}


Table 7

Bulk rock composition used in this study. $<$ LD, below limit of detection.

\begin{tabular}{|c|c|c|c|c|c|c|}
\hline Sample & AV-08-28d & AV-08-32a & AV-08-33 & AV-08-13 & AV-08-15 & PU-08-10 \\
\hline $\mathrm{SiO}_{2}$ & 69.2 & 69.64 & 71.68 & 73.85 & 59.54 & 61.3 \\
\hline $\mathrm{TiO}_{2}$ & 0.78 & 0.8 & 0.66 & 0.52 & 0.90 & 0.94 \\
\hline $\mathrm{Al}_{2} \mathrm{O}_{3}$ & 14.28 & 13.76 & 12.4 & 13.25 & 19.23 & 15.55 \\
\hline $\mathrm{FeO}$ & 5.29 & 4.81 & 5.47 & 3.34 & 7.16 & 8.59 \\
\hline $\mathrm{MnO}$ & 0.08 & 0.07 & 0.12 & 0.06 & 0.08 & 0.09 \\
\hline $\mathrm{MgO}$ & 1.89 & 1.73 & 1.69 & 0.99 & 2.12 & 2.05 \\
\hline $\mathrm{CaO}$ & 1.76 & 1.77 & 1.81 & 0.78 & 0.56 & 0.44 \\
\hline $\mathrm{Na}_{2} \mathrm{O}$ & 1.52 & 2.41 & 2 & 2.35 & 1.26 & 1.39 \\
\hline $\mathrm{K}_{2} \mathrm{O}$ & 2.25 & 2.61 & 2.21 & 3.36 & 4.53 & 3.74 \\
\hline $\mathrm{P}_{2} \mathrm{O}_{5}$ & 0.2 & $<$ LD & $<\mathrm{LD}$ & $<$ LD & 1.75 & 0.39 \\
\hline LOI & 2.15 & 1.63 & 1.22 & 1.58 & 2.17 & 3.11 \\
\hline Total & 99.4 & 99.23 & 99.27 & 100.08 & 99.20 & 97.59 \\
\hline $\mathrm{MgO} /(\mathrm{FeO}+\mathrm{MgO})$ & 0.26 & 0.26 & 0.24 & 0.23 & 0.23 & 0.19 \\
\hline
\end{tabular}

AV-08-15 during crystallization of sillimanite and the metastability of andalusite (Fig. $3 \mathrm{a} \&$ b) constrains the $P-T_{\max }$ at $4 \pm 2 \mathrm{kbar}$ and $620 \pm$ $50{ }^{\circ} \mathrm{C}$ (Fig. 8).

In sample AV-08-13, the observed mineral assemblage, $\mathrm{X}_{\mathrm{Mg}}$ of biotite (0.36), $\mathrm{X}_{\mathrm{Ab}}(0.83)$ and $\mathrm{RSCM}$ thermometry $\left(580 \pm 50{ }^{\circ} \mathrm{C}\right)$ show that the $P-T_{\max }$ lies in the field of biotite + plagioclase $+\mathrm{K}$-feldspar + muscovite + andalusite + quartz mineral assemblage (Appendix $C$., Fig. 1). Estimated $P-T_{\max }$ are of $3 \pm 2 \mathrm{kbar}$ and $580 \pm 50{ }^{\circ} \mathrm{C}$.

\subsubsection{Garnet-bearing migmatites}

Four garnet-bearing migmatites have been selected, three samples were collected from the eastern cross-section near the La Bocana locality and represent different structural levels: AV-08-28d (Fig. 9), AV-08-32a (Fig. 10) and AV-08-33 (Appendix C. Fig. 3) (see position in Fig. 4). The fourth sample, PU-08-10 (Appendix C. Fig. 4), which is located in the same upper structural level as sample AV-08-27, belongs to the western cross-section. The bulk compositions used in the calculations are presented in Table 7. All pseudosections were made with the assumption that the bulk composition of our samples during garnet crystallization did not significantly change. However, melt loss or gain is a widely accepted feature of migmatites (e.g., Brown, 2002, 2007; Kriegsman, 2001; White and Powell, 2002) that could strongly influence the bulk composition, and consequently, the mineral assemblage of the rocks. In order to investigate the effect of melt transfer, we considered $T-X_{\text {melt }}$ pseudosections (Appendix C. Fig. 2). $T-X_{\text {melt }}$ pseudosections show the characteristic migmatitic mineral assemblage field, the positions of $X_{\mathrm{Alm}}, X_{\mathrm{Grs}}, X_{M g}$ of biotite and $X_{A b}$ isopleths and thus peak $P-T$ conditions estimates at temperature above $690{ }^{\circ} \mathrm{C}$, are adversely affected by either loss or gain of melt.

The supra-solidus domain, between the stability field of kyanite and cordierite (Figs $9 \& 10$ ), is characterized by the mineral assemblage observed in the lower La Bocaca unit: biotite + garnet + plagioclase + $\mathrm{K}$-feldspar + sillimanite + quartz. Pressure- $T$ conditions were refined by contouring the $X_{A l m}$ and $X_{G r s}$ of garnet, $X_{M g}$ of biotite and $X_{A b}$ of plagioclase on each $P-T$ pseudosections.
In sample AV-08-28d, garnet is modeled in all the $P-T$ range and muscovite is absent of sub-solidus-region. The absence of muscovite in subsolidus domain can be related to extraction of low density melt produced during associated muscovite dehydration melting. $P$ $T_{\max }$ equilibration of garnet (Fig. 9) is of $7 \pm 2 \mathrm{kbar}$ and $760 \pm 50{ }^{\circ} \mathrm{C}$ $\left(X_{A l m}=0.73, X_{G r s}=0.05\right)$. Biotite equilibration (Fig. 9) is likely to have occurred at higher temperature ranging from 800 to $840{ }^{\circ} \mathrm{C}$ $\left(X_{M g}=0.49\right.$ to 0.59$)$, compatible with plagioclase composition $\left(X_{A b}=0.67\right)$ in schlieren. This apparent discrepancy which is also observed in AV-08-32 and AV-08-33 samples (see Fig. 10 and Figs 3 \& 4 in Appendix C.) can be explained either by requilibration of garnet during crystallization of residual melt, or by the difficulty to estimate active bulk composition during partial melting due to inherited metastable phases as Ti-bearing phases.

The stability of Ti-bearing oxide provides a good constraint for pressure. Rutile-bearing assemblages that have been observed in the lowest structural domains (e.g., sample AV-08-33) are restricted to pressure conditions above $7.0 \mathrm{kbar}$ (Fig. 3 in Appendix B). Whereas Ti-bearing phases have been observed in all examined samples, in modeled pseudosections Ti-bearing phases, in suprasolidus conditions, are restricted to domains of high temperature $\left(>780-800{ }^{\circ} \mathrm{C}\right)$. Pseudosections model theorical mineral assemblages at each $P-T$ conditions without taking into account metastability or heterogenous reactions during metamorphism. In order to model the metastable Ti-bearing phases in suprasolidus domain we artificially saturated each pseudosection in $\mathrm{Ti}$ and reported the results over the original pseudosections (Figs. 9 \& 10).

Results of pseudosections show that $P-T_{\max }$ conditions in garnetbearing migmatites rise from $750 \pm 50{ }^{\circ} \mathrm{C}$ for PU- $08-10$ to $750-820{ }^{\circ} \mathrm{C}$ for AV-08-28d, AV-08-32a and AV-08-33 while pressure increase continuously from 6 to 8 kbar for AV-08-28d, AV-08-32a and AV-08-33 and is $~ 7$ kbar for PU-08-10.

\section{Geochronological results}

U-Th-Pb data obtained by SHRIMP at the University of Western Australia, Perth, Australia, and LA-ICPMS methods at the University

Table 8

Solution and end-members used for the pseudosections (see Figs. 7 \& 8). See Perple_X documentation (http://www.perplex.ethz.ch) for more detailed informations.

\begin{tabular}{|c|c|c|c|}
\hline Phase & Solution model label in perpleX & End members & References \\
\hline Chlorite & $\mathrm{Chl}(\mathrm{HP})$ & Clinochlore-daphnite-amesite-Al free chlorite & Holland and Powell, 1998 \\
\hline Plagioclase & $\mathrm{Pl}(\mathrm{h})$ & High albite-anorthite & Newton et al., 1980 \\
\hline Garnet & $\mathrm{Gt}(\mathrm{HP})$ & Spessartine-grossular-pyrope-almandine & Holland and Powell, 1998 \\
\hline Cordierite & hCrd & Fe-cordierite-Mn-cordierite-cordierite & Holland and Powell, 1998 \\
\hline Melt & melt(HP) & $\begin{array}{l}\mathrm{H}_{2} \mathrm{O} \text { liquid-fayalite liquid-forsterite liquid-albite liquid-anorthite } \\
\text { liquid-K-feldspar liquid-sillimanite liquid-Silica liquid }\end{array}$ & Holland and Powell, 1998 \\
\hline Orthopyroxene & $\mathrm{Opx}(\mathrm{HP})$ & Enstatite-ferrosilite & Holland and Powell, 1998 \\
\hline White-mica & $\operatorname{Mica}(\mathrm{CHA})$ & Muscovite-celadonite-Fe-celadonite-paragonite-margarite & Holland and Powell, 1998 \\
\hline Staurolite & $\mathrm{St}(\mathrm{HP})$ & Fe-staurolite-Mg-staurolite-Mn-staurolite & Holland and Powell, 1998 \\
\hline Biotite & $\mathrm{Bio}(\mathrm{TCC})$ & Mn-biotite-Ti biotite-annite-phlogopite-eastonite-Fe3 + Biotite & Tajcmanová et al., 2009 \\
\hline
\end{tabular}




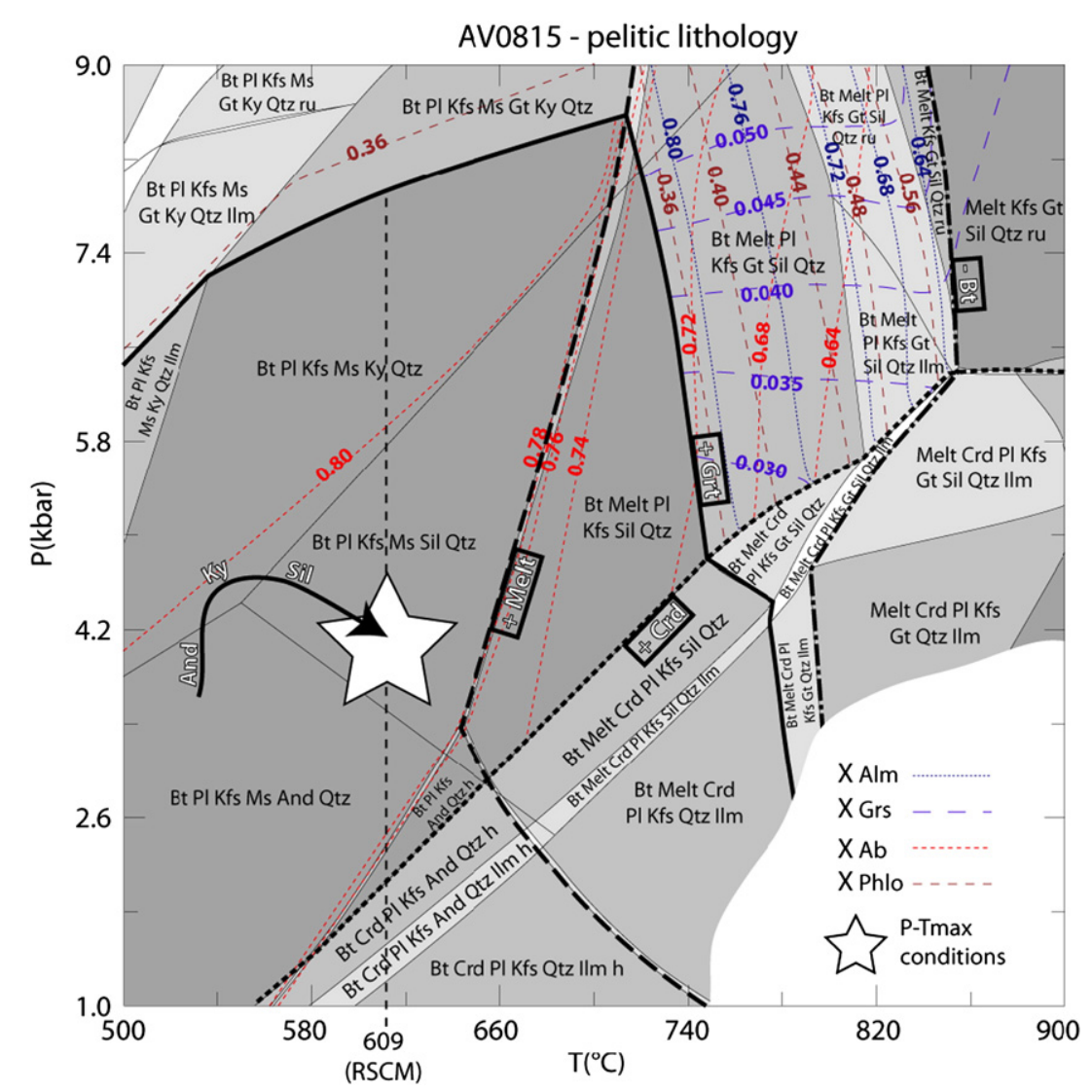

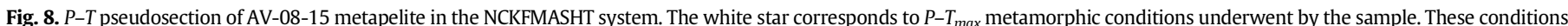

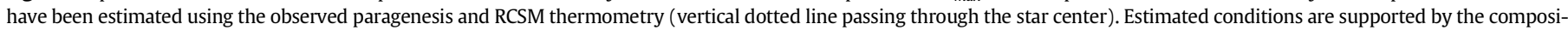

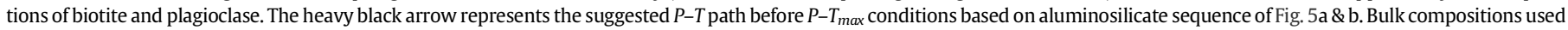

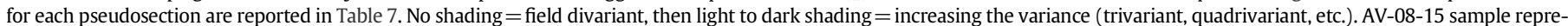

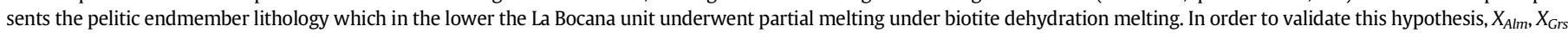

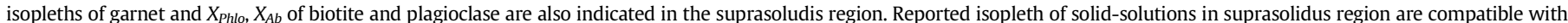

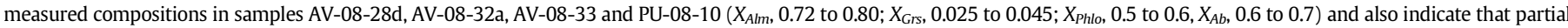

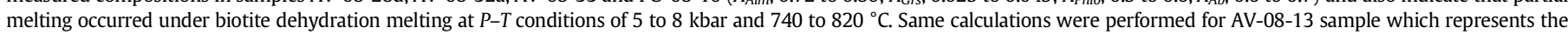
psammitic end-member lithology observed in the La Victoria unit. Results are presented in supplementary data and show similar results.

of Clermont-Ferrand, France, on zircon and monazite are presented in Tables 9 and 10, in Fig. 11 and Appendix A.

\subsection{Monazites}

Ten subhedral and eighteen anhedral monazite grains were analysed in situ in thin sections by LA-ICMPS, for the PU-08-10 and VI-08-12 garnet-bearing migmatitic samples of the La Bocana unit, respectively (Fig. 11a \& b). They are compositionally homogeneous as no zoning was observed on backscattered images. Monazite ${ }^{208} \mathrm{~Pb} /$

${ }^{232} \mathrm{Th}$ ages for sample PU-08-10 range from $228.9 \pm 4.7$ to $219.9 \pm$ 4.5 and give a mean age of $223.2 \pm 2.2 \mathrm{Ma}$ (Fig. 11a). No inherited monazite grains were dated. Monazite ${ }^{208} \mathrm{~Pb} /{ }^{232} \mathrm{Th}$ ages for $\mathrm{VI}-08-12$ range from $229 \pm 7$ to $219 \pm 5 \mathrm{Ma}$ and give a mean age of $226.0 \pm$ 1.3 Ma (Fig. 11b). Analyzed grains 1 and 6 of VI-08-12 sample exhibit a Th/U ratio of 0.6 , and ${ }^{208} \mathrm{~Pb} /{ }^{232} \mathrm{Th}$ ages of $235.7 \pm 14.5 \mathrm{Ma}$ and $236 \pm 19.5 \mathrm{Ma}$ (Table 9). The $\mathrm{Th} / \mathrm{U}$ ratio (0.6) is consistent with xenotime rather than monazite. ${ }^{208} \mathrm{~Pb} /{ }^{232} \mathrm{Th}$ dating on another xenotime grain yielded an older age $(362.5 \pm 12.3 \mathrm{Ma})$ with higher error and was considered in the mean age calculation.

\subsection{Zircon}

Fourteen zircon grains of AV-08-31 and ten zircon grains of AV-08-28d garnet-bearing migmatitic samples of the La Bocana unit were imaged and dated in situ by SHRIMP (Fig. 11c \& d). The grains are subhedral to rounded, and are usually composite with a core surrounded by multiple rims. Most of the crystal cores are detrital and characterized by a corroded outline. These cores exhibit a magmatic Th/U ratio $(>0.1)$ and yield ${ }^{206} \mathrm{~Pb} /{ }^{238} \mathrm{U}$ ages ranging from late Archean to Ordovician. Rims are characterized by metamorphic $\mathrm{Th} / \mathrm{U}$ ratio (0.01 to 0.1 ) and are concordant. $U$ contents are lower in the inherited core (90-120 ppm) than in the rim $(230-280 \mathrm{ppm}) .{ }^{206} \mathrm{~Pb} /$ ${ }^{238} \mathrm{U}$ ages on zircon rims from sample AV-08-31 range from $236 \pm 3$ to $224 \pm 3 \mathrm{Ma}$, with a mean age of $229.3 \pm 2.4 \mathrm{Ma}$ (Fig. 11c). $\mathrm{Rim}{ }^{206} \mathrm{~Pb} /$ ${ }^{238} \mathrm{U}$ ages of AV-08-28d range from $221 \pm 4 \mathrm{Ma}$ to $229 \pm 3 \mathrm{Ma}$, with a mean age of $225.7 \pm 6.5 \mathrm{Ma}$ (Fig. 11d). No systematic ages were obtained on multiple overgrowths. However, ages obtained from the rims yielded undistinguishable Late Triassic ages within the analytical uncertainty.

\section{Discussion}

Petrological, thermobarometric and geochronological informations acquired in this study are combined to reconstruct the thermal structure and the possible evolution of the south-western Ecuadorian margin during Late Triassic times.

\subsection{Geochronological implications}

The U-Th-Pb in situ ages on garnet-bearing migmatites of the La Bocana unit are coherent with, but more precise than, the age of 


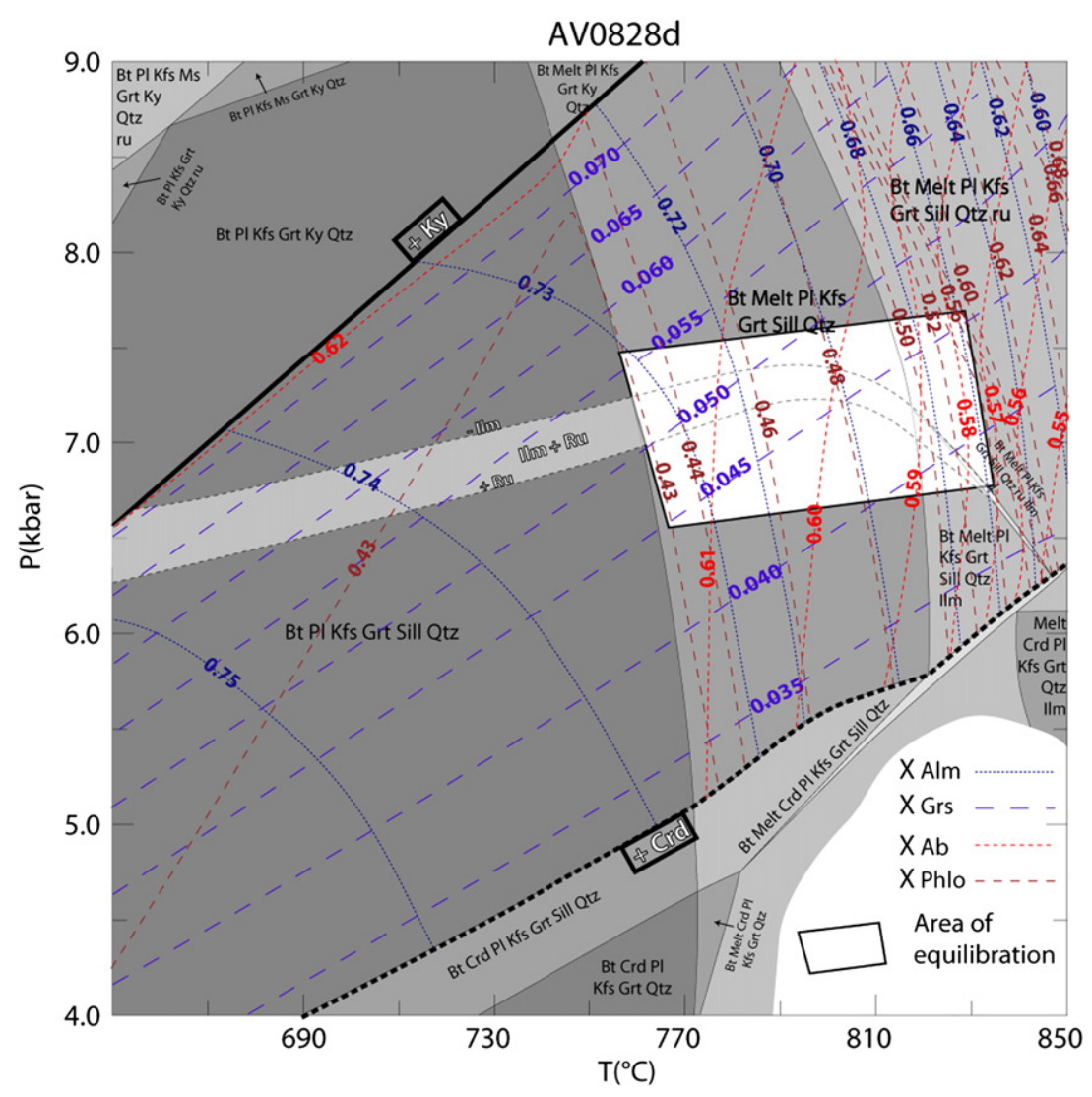

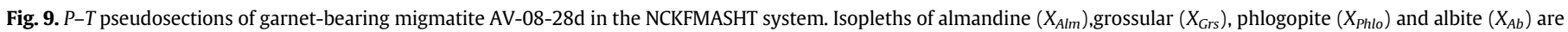

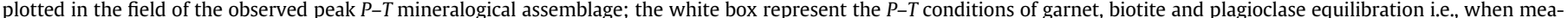

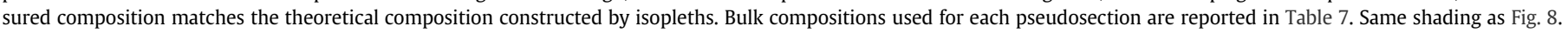

$219 \pm 22$ Ma obtained by a Sm/Nd whole-rock/garnet isochron on similar migmatites (Aspden et al., 1992a, 1992b). The Piedras unit has been dated at $221 \pm 17$ Ma by the $\mathrm{U}-\mathrm{Pb}$ method on magmatic zircons (Noble et al., 1997), and at $226 \pm 1.8 \mathrm{Ma}$ by the $\mathrm{Ar} / \mathrm{Ar}$ method on hornblende (Gabriele, 2002). These two ages constrain the age of emplacement and crystallization of the Piedras gabbroic unit before $226 \pm 1.8 \mathrm{Ma}$. The migmatitic ages obtained in this study (235-220 Ma) are compatible with a single Triassic thermal event producing the Piedras gabbroic unit and the Marcabeli S-type granitoid unit (227.5 $\pm 0.8 \mathrm{Ma}$, Noble et al., 1997). The $\mathrm{Ar} / \mathrm{Ar}$ age of $225.3 \pm$ 1.7 Ma on amphibole (Gabriele, 2002) for the Arenillas-Panupalí blueschist unit records either the cooling of the rock below $550 \pm$ $50{ }^{\circ} \mathrm{C}$ isotherm (Harrison and McDougall, 1981), or mineral crystallized below $550 \pm 50{ }^{\circ} \mathrm{C}$. The peak $P-T$ conditions of the Arenillas-Panupali unit have been estimated at $9 \mathrm{kbar}$ and $300{ }^{\circ} \mathrm{C}$ (Gabriele, 2002), therefore the age at $225.3 \pm 178 \mathrm{Ma}$ dates the timing of the blueschist facies metamorphism. This age is statistically identical to the thermal event. However, the Arenillas-Panupalí blueschist unit, which was retrogressed under greenschist facies conditions (Gabriele, 2002), did not undergo any high temperature overprint. Therefore, underplating of the Arenillas-Panupali oceanic unit postdated the thermal event. This interpretation is supported by the lack of zoning in migmatite garnets, which precludes a long cooling period. The timing of underthrusting of the Arenillas-Panupalí blueschist unit has important implications for the interpretation of the tectonic setting. The only setting to create blueschists is a subduction context (Ernst, 1988), and their exhumation mainly occurs in forearc regions (Cloos and Shreve, 1996; Guillot et al., 2009). Consequently, the age similarity for the whole Late Triassic metamorphic belt of El Oro massif implies that subduction was the only possible geodynamical setting that could produce anatexis and subsequent blueschist underplating.

\subsection{P-T conditions}

Estimates of $P-T$ conditions in a metamorphic complex are of primary interest and are highly dependent on the geodynamical setting. The continental sequence of the El Oro metamorphic complex has been interpreted either as a regional shear zone undergoing partial melting (Aspden et al., 1995), or as a tilted continental sequence (Gabriele, 2002). The increase in metamorphic grade to the north from unmetamorphosed sediments to high-grade migmatites has been interpreted either as resulting from the closing from the shear zone (Aspden et al., 1995), or as due to normal deepening in the crustal sequence (Gabriele, 2002). Peak P-T data are compiled in Fig. 12; and our results show an excellent correlation between increasing temperature and pressure conditions toward the north. This is supported by the typically observed southward escape path of melt within dilatant structures, which must have been originally upward. Consequently the present geometry of the El Oro metamorphic complex is not representative of that in the Late Triassic. As proposed by Gabriele (2002) on the basis of the increasing temperature conditions, the continental sequence has been tilted to acquire its present subvertical. Because the Early Cretaceous Raspas eclogitic complex also exhibits a subvertical (Aspden et al., 1995; Gabriele, 2002), tilting must have occurred during or after exhumation of the Raspas complex, i.e., in the Early Cretaceous or later. The unconformity of the gently dipping Celica-Lancones sediments (Jaillard et al., 1999) on the vertical La Victoria unit implies that tilting occurred before Albian times. The present-day geometry has to be rotated $\sim 90^{\circ}$ along an east-west horizontal axis in order to reconstruct the original geometry during the thermal event. Rotation of the present day transtensive dextral movement indicates a low angle top-tothe-east or top-to-the-west normal movement during migmatization. 


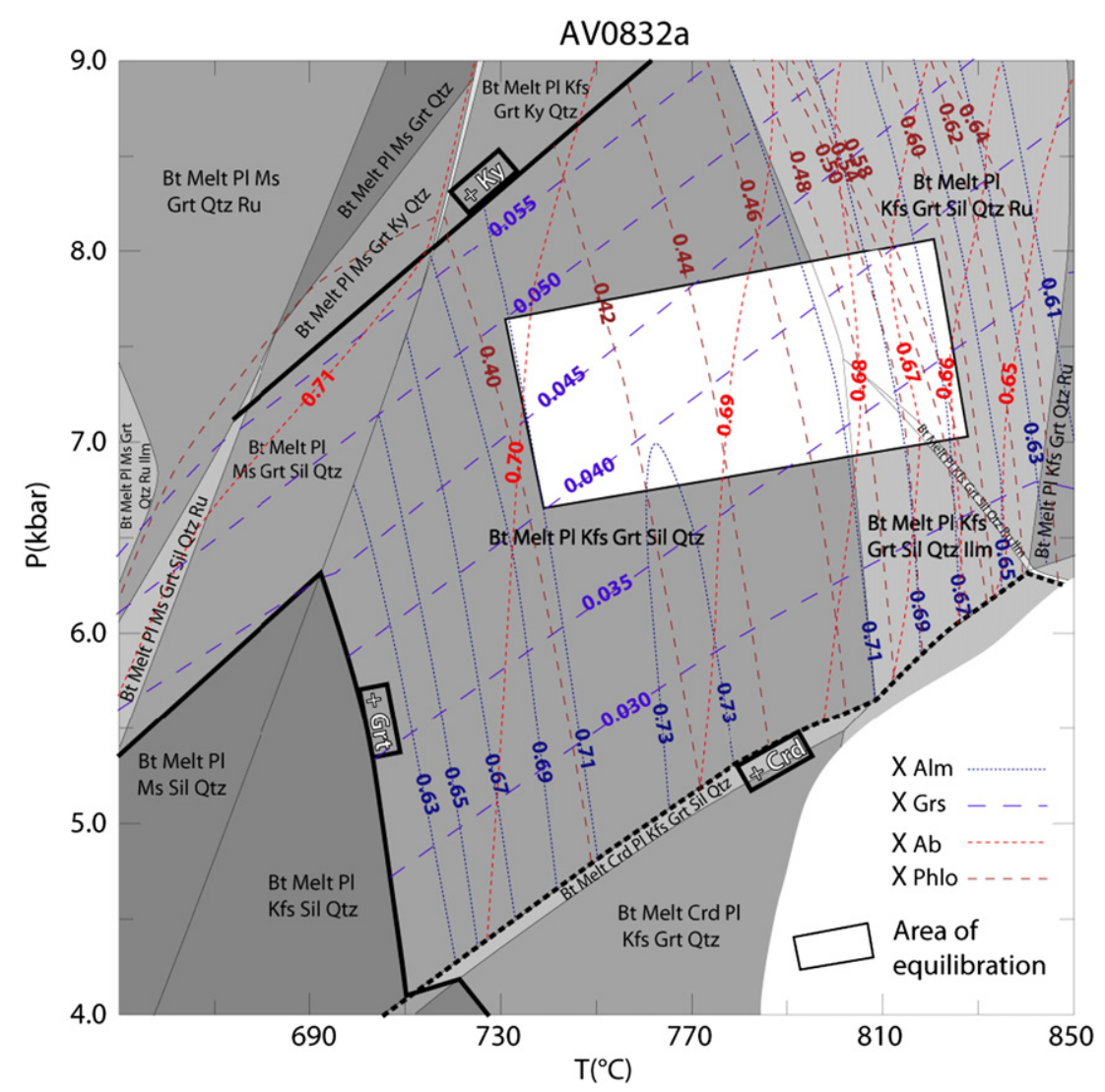

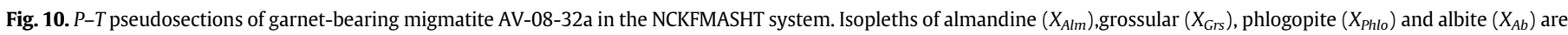

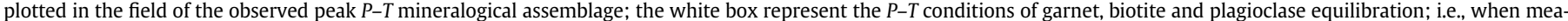

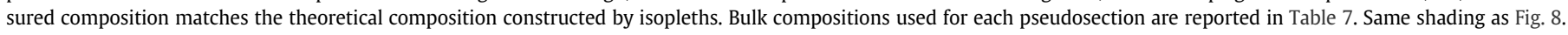

Table 9

LA-ICP-MS U-Pb analytical data for migmatitic rocks of La Bocana unit.

\begin{tabular}{|c|c|c|c|c|c|c|c|c|c|c|c|c|}
\hline \multirow[b]{2}{*}{ Sample } & \multirow[b]{2}{*}{ Analysis_\# } & \multirow{2}{*}{$\begin{array}{l}\mathrm{Pb} \\
(\mathrm{ppm})\end{array}$} & \multirow{2}{*}{$\begin{array}{l}\text { Th } \\
\text { (ppm) }\end{array}$} & \multirow{2}{*}{$\begin{array}{l}\mathrm{U} \\
(\mathrm{ppm})\end{array}$} & \multirow[b]{2}{*}{$\mathrm{Th} / \mathrm{U}$} & \multirow[b]{2}{*}{${ }^{208} \mathrm{~Pb} /{ }^{232} \mathrm{Th}$} & \multirow{2}{*}{$\frac{2 \sigma \text { error }}{{ }^{208} \mathrm{~Pb} /{ }^{232} \mathrm{Th}}$} & \multirow[b]{2}{*}{${ }^{206} \mathrm{~Pb} /{ }^{238} \mathrm{U}$} & \multirow{2}{*}{$\frac{2 \sigma \text { error }}{{ }^{206} \mathrm{~Pb} /{ }^{238} \mathrm{U}}$} & \multirow{2}{*}{$\frac{\text { Age (Ma) }}{{ }^{208} \mathrm{~Pb} /{ }^{232} \mathrm{Th}}$} & \multirow{2}{*}{$\frac{2 \sigma \text { error }}{{ }^{208} \mathrm{~Pb} /{ }^{232} \mathrm{Th}}$} & \multirow[b]{2}{*}{ Position } \\
\hline & & & & & & & & & & & & \\
\hline \multicolumn{13}{|c|}{ VI-08-12 } \\
\hline & 1 & 20 & 344 & 553 & 0.6 & 0.01173 & 0.00072 & 0.03728 & 0.00138 & 235.7 & 14.5 & Core \\
\hline & 2 & 460 & 40053 & 1726 & 23.2 & 0.01077 & 0.00026 & 0.03713 & 0.00110 & 216.5 & 5.0 & Core \\
\hline & 3 & 492 & 40421 & 1951 & 20.7 & 0.01123 & 0.00026 & 0.03852 & 0.00106 & 225.7 & 5.1 & Core \\
\hline & 4 & 494 & 45777 & 782 & 58.5 & 0.01141 & 0.00026 & 0.03770 & 0.00114 & 229.2 & 5.2 & Core \\
\hline & 5 & 660 & 54308 & 3344 & 16.2 & 0.01114 & 0.00026 & 0.03878 & 0.00108 & 224.0 & 5.0 & Core \\
\hline & 6 & 32 & 507 & 917 & 0.6 & 0.01179 & 0.00098 & 0.03503 & 0.00152 & 236.9 & 19.5 & Core \\
\hline & 7 & 599 & 51791 & 1969 & 26.3 & 0.01135 & 0.00024 & 0.03612 & 0.00092 & 228.1 & 4.8 & Core \\
\hline & 8 & 645 & 53487 & 2881 & 18.6 & 0.01135 & 0.00024 & 0.03658 & 0.00092 & 228.1 & 4.8 & Core \\
\hline & 9 & 783 & 52372 & 8674 & 6.0 & 0.01118 & 0.00024 & 0.03546 & 0.00086 & 224.6 & 4.7 & Core \\
\hline & 10 & 660 & 47882 & 5640 & 8.5 & 0.01124 & 0.00024 & 0.03666 & 0.00090 & 225.9 & 4.7 & Core \\
\hline & 11 & 56 & 601 & 987 & 0.6 & 0.01810 & 0.00062 & 0.05861 & 0.00158 & 362.5 & 12.3 & Core \\
\hline & 12 & 545 & 45829 & 2298 & 19.9 & 0.01132 & 0.00024 & 0.03599 & 0.00092 & 227.6 & 4.8 & Core \\
\hline & 13 & 729 & 62434 & 2600 & 24.0 & 0.01115 & 0.00024 & 0.03844 & 0.00114 & 224.1 & 4.8 & Core \\
\hline & 14 & 69 & 5819 & 213 & 27.4 & 0.01139 & 0.00034 & 0.03698 & 0.00284 & 229.0 & 6.9 & Core \\
\hline & 15 & 516 & 42647 & 2440 & 17.5 & 0.01134 & 0.00024 & 0.03504 & 0.00088 & 228.0 & 4.8 & Core \\
\hline & 16 & 606 & 52860 & 2545 & 20.8 & 0.01109 & 0.00024 & 0.03491 & 0.00090 & 223.0 & 4.7 & Core \\
\hline & 17 & 552 & 44673 & 2876 & 15.5 & 0.01104 & 0.00024 & 0.03910 & 0.00100 & 221.8 & 4.6 & Core \\
\hline \multicolumn{13}{|c|}{ PU-08-10 } \\
\hline & 1 & 574 & 45262 & 3778 & 12.0 & 0.01123 & 0.00022 & 0.03560 & 0.00084 & 225.8 & 4.6 & Core \\
\hline & 2 & 651 & 45939 & 6723 & 6.8 & 0.01095 & 0.00022 & 0.03531 & 0.00084 & 220.2 & 4.5 & Core \\
\hline & 3 & 649 & 46894 & 6276 & 7.5 & 0.01094 & 0.00022 & 0.03581 & 0.00084 & 219.9 & 4.5 & Core \\
\hline & 4 & 633 & 48186 & 5208 & 9.3 & 0.01104 & 0.00022 & 0.03535 & 0.00084 & 221.8 & 4.5 & Core \\
\hline & 5 & 574 & 45428 & 3680 & 12.3 & 0.01107 & 0.00022 & 0.03602 & 0.00088 & 222.5 & 4.5 & Core \\
\hline & 6 & 465 & 38568 & 2501 & 15.4 & 0.01096 & 0.00022 & 0.03591 & 0.00090 & 220.4 & 4.5 & Core \\
\hline & 7 & 535 & 32502 & 6709 & 4.8 & 0.01139 & 0.00024 & 0.03546 & 0.00084 & 228.9 & 4.7 & Core \\
\hline & 8 & 497 & 30691 & 6063 & 5.1 & 0.01124 & 0.00024 & 0.03642 & 0.00088 & 226.0 & 4.6 & Core \\
\hline & 9 & 851 & 53582 & 1688 & 31.8 & 0.01124 & 0.00024 & 0.03697 & 0.00092 & 225.9 & 4.6 & Core \\
\hline & 10 & 868 & 48776 & 2888 & 16.9 & 0.01100 & 0.00022 & 0.03692 & 0.00092 & 221.2 & 4.5 & Core \\
\hline
\end{tabular}


Table 10

SHRIMP U-Pb analytical data for migmatitic rocks of La Bocana unit

\begin{tabular}{|c|c|c|c|c|c|c|c|c|c|c|c|c|c|c|c|}
\hline \multirow[b]{2}{*}{ Sample } & \multirow[b]{2}{*}{ Analysis_\# } & \multirow{2}{*}{$\begin{array}{l}\text { Th } \\
\text { (ppm) }\end{array}$} & \multirow{2}{*}{$\begin{array}{l}\text { U } \\
(\mathrm{ppm})\end{array}$} & \multirow[b]{2}{*}{$\mathrm{Th} / \mathrm{U}$} & \multirow[b]{2}{*}{$\begin{array}{l}{ }^{207} \mathrm{~Pb} / \\
{ }^{206} \mathrm{~Pb}\end{array}$} & \multirow{2}{*}{$\begin{array}{l}\frac{2 \sigma \text { error }}{{ }^{208} \mathrm{~Pb} /} \\
{ }^{232} \mathrm{Th}\end{array}$} & \multirow[b]{2}{*}{$\begin{array}{l}{ }^{206} \mathrm{~Pb} / \\
{ }^{238} \mathrm{~Pb}\end{array}$} & \multirow{2}{*}{$\begin{array}{l}\frac{2 \sigma \text { error }}{{ }^{206} \mathrm{~Pb} /} \\
{ }^{238} \mathrm{~Pb}\end{array}$} & \multirow[b]{2}{*}{$\begin{array}{l}{ }^{207} \mathrm{~Pb} / \\
{ }^{235} \mathrm{~Pb}\end{array}$} & \multirow{2}{*}{$\begin{array}{l}\frac{2 \sigma \text { error }}{207 \mathrm{~Pb} /} \\
{ }^{235} \mathrm{~Pb}\end{array}$} & \multirow[b]{2}{*}{$\begin{array}{l}{ }^{208} \mathrm{~Pb} / \\
{ }^{206} \mathrm{~Pb}\end{array}$} & \multirow{2}{*}{$\begin{array}{l}\frac{2 \sigma \text { error }}{{ }^{208} \mathrm{~Pb} /} \\
{ }^{206} \mathrm{~Pb}\end{array}$} & \multirow{2}{*}{$\begin{array}{l}\frac{\text { Age (Ma) }}{{ }^{206} \mathrm{~Pb} /} \\
{ }^{238} \mathrm{U}\end{array}$} & \multirow{2}{*}{$\begin{array}{l}\frac{2 \sigma \text { error }}{{ }^{206} \mathrm{~Pb} /} \\
{ }^{238} \mathrm{U}\end{array}$} & \multirow[b]{2}{*}{ Position } \\
\hline & & & & & & & & & & & & & & & \\
\hline \multicolumn{16}{|c|}{ AV-08-31 } \\
\hline & 1 & 27 & 262 & 0.1 & 0.0507 & 5.9 & 0.037 & 1.4 & 0.29 & 10.2 & 0.053 & 6.9 & 233 & 3 & rim \\
\hline & 2 & 19 & 297 & 0.1 & 0.1248 & 3.5 & 0.036 & 2.5 & 0.28 & 32.4 & 0.027 & 2.8 & 226 & 6 & core \\
\hline & 3 & 19 & 278 & 0.1 & 0.0501 & 6.2 & 0.036 & 1.5 & 0.27 & 14.4 & 0.035 & 8.6 & 230 & 3 & rim \\
\hline & 4 & 189 & 119 & 1.6 & 0.0630 & 5.2 & 0.107 & 1.3 & 0.94 & 7.4 & 0.515 & 1.6 & 653 & 8 & core \\
\hline & 5 & 12 & 219 & 0.1 & 0.0479 & 6.6 & 0.036 & 1.1 & 0.29 & 5.5 & 0.047 & 10.3 & 231 & 2 & rim \\
\hline & 6 & 4 & 249 & 0.0 & 0.0505 & 6.0 & 0.035 & 1.1 & 0.19 & 10.3 & -0.022 & 17.0 & 223 & 2 & core \\
\hline & 7 & 16 & 236 & 0.1 & 0.0545 & 6.1 & 0.035 & 1.3 & 0.22 & 15.0 & 0.006 & 8.1 & 224 & 3 & rim \\
\hline & 8 & 55 & 90 & 0.6 & 0.0650 & 4.7 & 0.129 & 1.3 & 1.16 & 4.9 & 0.200 & 2.8 & 782 & 9 & core \\
\hline & 9 & 23 & 224 & 0.1 & 0.0494 & 6.3 & 0.036 & 1.1 & 0.31 & 5.1 & 0.067 & 7.3 & 231 & 2 & rim \\
\hline & 10 & 174 & 624 & 0.3 & 0.0584 & 2.4 & 0.078 & 1.0 & 0.62 & 2.6 & 0.098 & 1.9 & 482 & 5 & rim \\
\hline & 11 & 24 & 507 & 0.0 & 0.0602 & 2.6 & 0.095 & 2.7 & 0.80 & 3.9 & 0.018 & 4.6 & 583 & 15 & core \\
\hline & 12 & 435 & 125 & 3.5 & 0.0622 & 4.4 & 0.095 & 1.3 & 0.91 & 8.0 & 1.114 & 1.2 & 584 & 7 & core \\
\hline & 13 & 296 & 146 & 2.0 & 0.0631 & 4.1 & 0.094 & 2.3 & 0.81 & 4.7 & 0.650 & 1.4 & 577 & 13 & core \\
\hline & 14 & 26 & 240 & 0.1 & 0.0505 & 6.1 & 0.036 & 1.7 & 0.25 & 16.3 & 0.038 & 7.0 & 229 & 4 & core \\
\hline & 15 & 116 & 180 & 0.6 & 0.1143 & 1.3 & 0.513 & 2.7 & 8.06 & 3.0 & 0.162 & 8.4 & 2671 & 59 & core \\
\hline & 16 & 137 & 582 & 0.2 & 0.1472 & 4.7 & 0.358 & 1.0 & 7.27 & 4.8 & 0.071 & 6.2 & 1974 & 17 & core \\
\hline & 17 & 27 & 283 & 0.1 & 0.0519 & 5.1 & 0.037 & 1.3 & 0.26 & 5.3 & 0.038 & 6.1 & 232 & 3 & rim \\
\hline & 18 & 55 & 450 & 0.1 & 0.0496 & 4.5 & 0.036 & 1.0 & 0.25 & 4.6 & 0.038 & 5.2 & 228 & 2 & rim \\
\hline & 19 & 89 & 172 & 0.5 & 0.0492 & 6.3 & 0.037 & 1.1 & 0.24 & 7.5 & 0.155 & 3.6 & 236 & 3 & core \\
\hline & 20 & 28 & 309 & 0.1 & 0.0513 & 5.0 & 0.036 & 1.3 & 0.26 & 5.1 & 0.033 & 6.2 & 231 & 3 & rim \\
\hline \multicolumn{16}{|c|}{ AV-08-28d } \\
\hline & 1 & 26 & 302 & 0.1 & 0.0572 & 3.9 & 0.052 & 5.3 & 0.41 & 6.6 & 0.032 & 5.2 & 329 & 17 & rim \\
\hline & 2 & 391 & 377 & 1.0 & 0.0704 & 2.1 & 0.169 & 3.7 & 1.64 & 4.2 & 0.322 & 4.9 & 1009 & 34 & core \\
\hline & 3 & 115 & 286 & 0.4 & 0.0653 & 2.9 & 0.087 & 1.5 & 0.78 & 3.3 & 0.132 & 4.9 & 538 & 8 & rim \\
\hline & 4 & 50 & 1745 & 0.0 & 0.0561 & 1.7 & 0.072 & 2.0 & 0.56 & 2.6 & 0.008 & 7.3 & 447 & 9 & core \\
\hline & 5 & 62 & 255 & 0.2 & 0.0645 & 5.1 & 0.085 & 3.7 & 0.76 & 6.3 & 0.074 & 3.7 & 525 & 19 & core \\
\hline & 6 & 84 & 460 & 0.2 & 0.0545 & 3.7 & 0.040 & 1.9 & 0.30 & 4.1 & 0.056 & 3.7 & 252 & 5 & core \\
\hline & 7 & 18 & 242 & 0.1 & 0.0516 & 5.7 & 0.035 & 1.7 & 0.25 & 6.0 & 0.021 & 9.2 & 221 & 4 & rim \\
\hline & 8 & 77 & 186 & 0.4 & 0.0496 & 5.8 & 0.089 & 2.9 & 0.60 & 6.5 & 0.116 & 2.6 & 547 & 15 & core \\
\hline & 9 & 11 & 203 & 0.1 & 0.0546 & 6.0 & 0.035 & 1.5 & 0.26 & 6.2 & 0.019 & 10.3 & 223 & 3 & rim \\
\hline & 10 & 26 & 57 & 0.5 & 0.1926 & 4.5 & 0.538 & 1.8 & 14.28 & 4.9 & 0.140 & 2.1 & 2774 & 41 & core \\
\hline & 11 & 22 & 591 & 0.0 & 0.0562 & 2.7 & 0.071 & 2.6 & 0.55 & 3.7 & 0.011 & 4.8 & 443 & 11 & rim \\
\hline & 12 & 31 & 74 & 0.4 & 0.0777 & 4.0 & 0.164 & 1.7 & 1.75 & 4.4 & 0.140 & 3.1 & 977 & 15 & core \\
\hline & 13 & 9 & 213 & 0.0 & 0.0499 & 14.4 & 0.036 & 1.7 & 0.25 & 14.5 & 0.012 & 10.9 & 226 & 4 & rim \\
\hline & 14 & 45 & 78 & 0.6 & 0.0567 & 5.8 & 0.087 & 2.7 & 0.68 & 6.4 & 0.188 & 3.3 & 536 & 14 & core \\
\hline & 15 & 40 & 383 & 0.1 & 0.0496 & 4.6 & 0.036 & 1.5 & 0.25 & 4.8 & 0.033 & 5.2 & 228 & 3 & rim \\
\hline & 16 & 21 & 51 & 0.4 & 0.0744 & 20.4 & 0.143 & 3.6 & 1.47 & 20.7 & 0.114 & 3.7 & 863 & 29 & core \\
\hline & 17 & 28 & 238 & 0.1 & 0.0621 & 3.8 & 0.072 & 2.3 & 0.62 & 4.5 & 0.073 & 3.6 & 451 & 10 & rim \\
\hline & 18 & 16 & 243 & 0.1 & 0.0492 & 5.4 & 0.036 & 1.5 & 0.25 & 5.6 & 0.023 & 8.1 & 229 & 3 & rim \\
\hline
\end{tabular}

Extension during Late Triassic times is supported by our mineralogical study: relict rutile in ilmenite marks decompression before garnet crystallization and observed kyanite recrystallizing into sillimanite during migmatization. Note that extension is assumed to have occurred in north-western South America at that time (e.g., Mišković et al., 2009; Vinasco et al., 2006).

$P-T$ estimates (Fig. 12) are direct proxies of the maximum geotherm during the early Late Triassic thermal anomaly. The pre-anatectic mineral assemblage in the La Victoria unit is recorded in the sample AV-08- 15 by andalusite statically re-equilibrated into kyanite. The thermal event is marked by a strong temperature increase and active deformation in all the studied samples marked by sillimanite metamorphic foliation. It defines a hot maximum geothermal gradient (Fig. 12). This Late Triassic maximum geotherm exhibits two segments. In the upper unit, the geotherm shape is convex with high $\mathrm{d} T / \mathrm{d} P$, whereas in the lower unit, the geotherm shape is linear, almost vertical, with very low $\mathrm{d} T / \mathrm{d} P$. The migmatitic layer is of about $10 \mathrm{~km}$ thick. In the upper part, in the $2.5 \mathrm{~km}$ thick white-mica dehydration melting zone, temperature rises from sub-solidus conditions to $750{ }^{\circ} \mathrm{C}$, thus representing a thermal gradient of $45{ }^{\circ} \mathrm{C} / \mathrm{km}$ (down to $6 \mathrm{kbar}$ ) (Fig. 12). In contrast, temperature estimates in the garnet-bearing migmatites of La Bocana ( $7 \mathrm{~km}$ thick) are rather constant, ranging from 750 to $820^{\circ} \mathrm{C}$, which exhibits a thermal gradient of $10{ }^{\circ} \mathrm{C} / \mathrm{km}$. However, in this part pressure increases northward from 6 to $8 \mathrm{kbar}$ (Fig. 12). Taking into account both melt modal percent and melt geometry we suggest that in the lower zone, maximum temperature is buffered, in part, by latent heat of biotite melting (e.g., Depine et al., 2008; Thompson and Connolly, 1995). Although the isothermal gradient could be explained by melt buffering alone, the high amount of melt and the lack of oriented structures and magmatic fabric within the garnet-bearing migmatites, suggest that convective motion occurred throughout the lower migmatitic zone.

\subsection{Heat source}

Migmatization of the semi-pelitic sequence of the La Bocana unit, i.e., switching from a relatively cool to a high geothermal gradient, requires heat input into the system. Three main possible mechanisms can provide additional heat to the continental crust (Bergantz, 1992; Huppert and Sparks, 1988): (1) crustal thinning and isotherm tightening, (2) crustal thickening and enhanced radiogenic production, (3) emplacement of a plutonic body close to, or within the system. The very strong convex geothermal gradient for the upper El Oro units cannot be explained by thermal conduction alone. We suggest that this strong apparent geothermal gradient results from the combined effect of crustal thinning, and heat input in the La Bocana garnet-bearing migmatites. The mixing zone between the gabbroic magma of the Piedras unit and the acid magma of the La Bocana unit implies that the Piedras gabbroic unit is an in situ magmatic body emplaced during Triassic times (Aspden et al., 1995; Noble et al., 1997), and is not a tectonically underplated oceanic terrane, as suggested by Gabriele (2002) and Bosch et al. (2002). Hence, we propose that crustal anatexis occurred, due to a combination of crustal thinning, heat transfer from 


\section{Monazites}
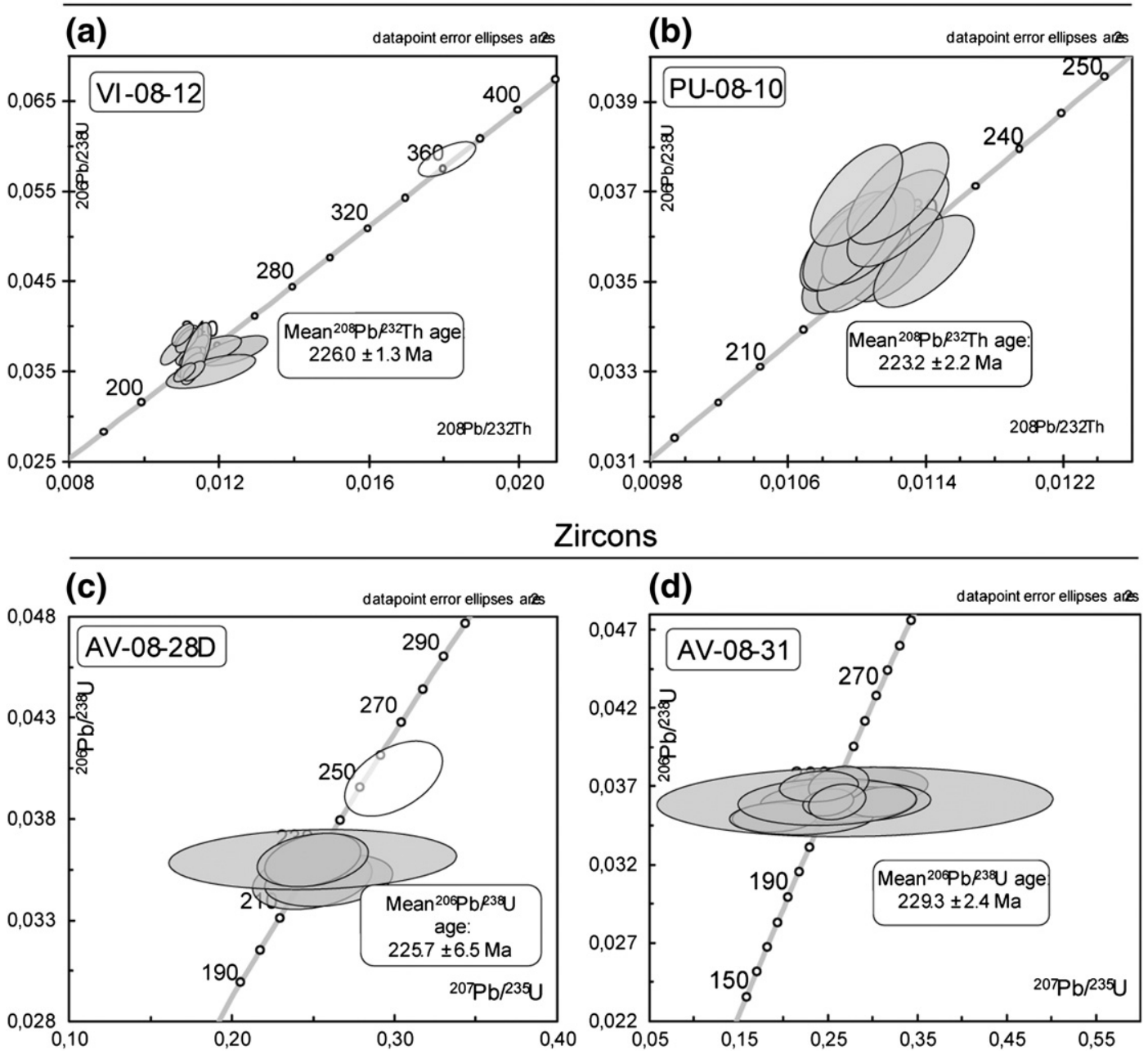

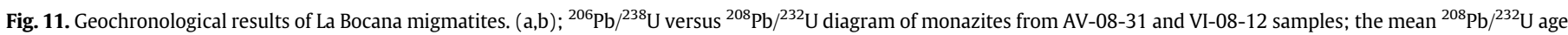
is indicated; (c, d) Concordia diagram of zircons from AV-08-31 and AV-08-28d samples, the mean ${ }^{206} \mathrm{~Pb} /{ }^{238} \mathrm{U}$ age is indicated.

the magmatic underplating of the Piedras unit, and latent heat of crystallization of the latter. Based on structural (Fig. 3a \& b) and mineralogical evidence (rutile to ilmenite), the El Oro metamorphic complex underwent crustal thinning before and during migmatization. Even though crustal thinning likely played a role in the isotherms tightening, it was probably not the only heat source that caused the anatectic event.

In contrast the magmatic emplacement of the high temperature $\left(>1000{ }^{\circ} \mathrm{C}\right.$ ) gabbroic Piedras unit before $226 \pm 1.8 \mathrm{Ma}$ at crustal root level (Noble et al., 1997) is likely to have provided the local heat source for migmatization (Aspden et al., 1995). This assumption is supported by the presence of a relatively thin magma mixing zone $(\sim 100 \mathrm{~m})$, where gabbroic melts from the Piedras gabbroic unit and granitic melt from the La Bocana unit can be observed. If we can locally attribute the main heat source to the emplacement of the Piedras unit, the formation of the Piedras gabbro itself remains an open question. Based on the MORB origin of the Piedras gabbro (Aspden et al., 1995; Bosch et al., 2002), we propose that upwelling and subsequent decompression of the asthenosphere beneath the forearc zone were able to produce this MORB-like magma.

\subsection{Geodynamical framework}

Based on the similar ages of Tres Lagunas granite and Marcabeli granitoid, Noble et al. (1997) proposed that the El Oro metamorphic complex and the Cordillera Real of Ecuador (Fig. 1) were contiguous during the emplacement of S-type granites. Inherited core of zircons of sample AV-08-28d (Table 10) show two main peak at 550-525 Ma and 450-440 Ma. Those ages demonstrate that the protolith of the La Bocana migmatites is probably metasediments equivalent to the Isimanchi and Chiguinda Unit of the Cordillera Real in Ecuador, which are believed to be autochthonous to the Gondwana margin (Chew et al., 2007). Therefore these inherited ages support the idea that the El Oro metamorphic complex belonged to the Cordillera Real of Ecuador before Cretaceous tilting of the El Oro metamorphic complex and exhumation of the ophiolitic Raspas complex.

While partial melting of a significant part of a forearc continental crustal section is a rare feature in the Andes, evidence of a late Triassic tectono-thermal anomaly associated with granitic production are widespread all along the western South-American margin. From north to south, evidences of late Triassic granitoid emplacement are: the Amaga Granitic Stock in Colombia at 227.6 $\pm 3.2 \mathrm{Ma}(\mathrm{U}-\mathrm{Pb}$, Vinasco et al., 2006), Tres Lagunas peraluminous granite within the Cordillera Real of Ecuador (see Fig. 1) at 227.3 $\pm 2.2 \mathrm{Ma}(\mathrm{U}-\mathrm{Pb}$, Litherland et al., 1994; Noble et al., 1997), Sabanilla migmatite of northern Peru at $230.4 \pm 3.2 \mathrm{Ma}$ (Chew et al., 2008), Zongo granitoid in Bolivia at 225.1 $\pm 4 \mathrm{Ma}$ (U-Pb, Farrar et al., 1990), and Constitución granite in Chile at $224 \pm 1 \mathrm{Ma}$ (Pb-Pb, Willner, 2005a, 2005b).These authors agree that crustal thinning occurred during crustal melting and granitic intrusion. Farther East in Ecuador, ages at $245.7 \pm 5.6$, $239.2 \pm 2.2,234.2 \pm 1.1$ and $234.66 \pm 0.95 \mathrm{Ma}$, from magmatic rims of zircons from acidic intrusive rocks the Loja Terrane and the El Oro metamorphic complex El Oro metamorphic complex, show the 


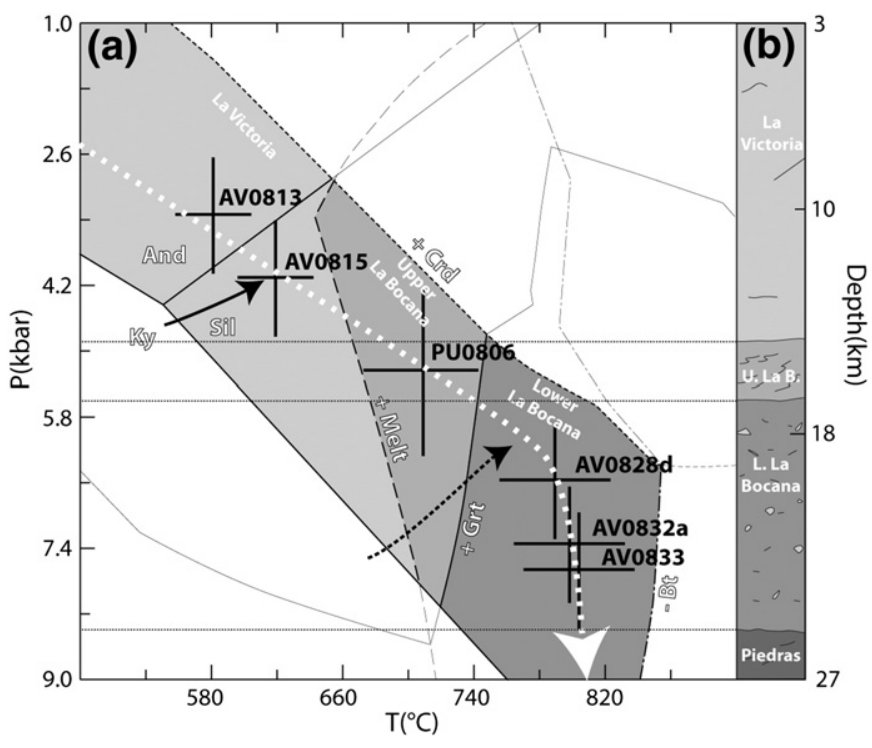

Fig. 12. $P-T$ diagram for El Oro metamorphic complex. (a) reported peak $P-T_{\max }$ conditions of studied samples in the simplified pseudosection of AV-08-15 sample (Fig. 8). Fields in greyscale show the domain of stability of observed mineral paragenesis of the La Victoria, the Upper and Lower La Bocana units. Note that the sample AV-08-15 (Fig. 5c) indicates that the pre-anatectic thermal history is marked by the transition from andalusite to kyanite, suggesting burial of the La Victoria unit before the high-temperature event (black arrow). The white and dashed arrows present the maximum $P-T$ condition recorded in the rock. We suggest that these last $P-T$ conditions could represent the geothermal gradient during Triassic times. (b) Schematic structura $\log$ of the El Oro from the La Victoria unit to the South to the Piedras unit to the North.

presence of a belt of Triassic migmatites across the southern Ecuador. Comparable events involving migmatization of the crust and S-type magmatism, dated from 260 to ca. $226 \mathrm{Ma}$, are well known from Northern Colombia to Northern Peru (Cardona et al., 2010; Mišković et al., 2009; Restrepo et al., 2011) indicating a long period of S-type magmatism during late Permian to late Triassic times.

In Colombia and Ecuador, intrusions of the Amaga and Tres Lagunas granites were interpreted as related to the Tethyan rifting between North and northern South America (Aspden and Litherland, 1992). However, Cardona et al. (2010) showed that subduction-related magmatism was active until late Permian, thus North and northern South America were separated during Permian-Triassic times precluding a continental rifting model. Moreover, in a rifting model intense extension would have occurred to upwell the asthenosphere at shallow depth. In the La Victoria and the La Bocana units such intense deformation has not been observed. However, in Chile, Willner (2005b) interpreted the intrusion of the Constitución granite as indicating retreat of the subducting slab. More recently, Bustamante et al. (2011) showed that in the Central Cordillera of Colombia, amphibolitic schists related to subduction were tectonically juxtaposed with Triassic migmatites and granulites during a late Triassic subduction event. The presence of an underplated oceanic slab (Arenillas-Panupalí unit) at $225 \mathrm{Ma}$ in the El Oro metamorphic complex and oceanic related underplated material in Colombia (Bustamante et al., 2011) imply that subduction was active at that time. Therefore, we interpret the thermal event affecting the Ecuadorian margin during Triassic times as the result of an anomaly arising from subduction processes.

During Permo-Triassic times, at 270-250 Ma, South America underwent a major shift in drift direction from northward to eastward directed (Geunal et al., 2010; Tomezzoli, 2009; Torsvik et al., 2008). This change in plate motion resulted from the counter-clockwise rotation of Gondwana during that time and ended in Late Triassic times, when South America resumed its movement toward the north (Torsvik et al., 2008).

We propose that this major eastward migration of South America provoked a rapid trench retreat, and a generalized extensional regime associated with a steep to vertical slab (Fig. 13a). Slab verticalization, due to slab anchorage at depth, could have triggered dehydration of the slab and upwelling of the asthenosphere (Zhu et al., 2011). In this model, partial melting of the asthenosphere likely generated MORB-type identical to the Piedras gabbroic unit. Underplating of magma and melting of the crust would have started in arc and backarc position (Zhu et al., 2011) during late Permian to Triassic times and finally extended to the forearc position in late Triassic. Subsequent underplating at $\sim 230 \mathrm{Ma}$ of the Piedras gabbroic unit at crustal root level (Fig. 13b) in turn triggered migmatization of the semi-pelitic sequence of the La Bocana unit and emplacement of the Marcabeli S-type granitoid (Noble et al., 1997). At the same time $(\approx 227 \mathrm{Ma}$ ), eastward migration of South America ceased (Torsvik et al., 2008), and we propose that slab breakoff occurred.

Based on U-Pb geochronology and geochemical study, Mišković et al. (2009) proposed that the Permian-Triassic magmatism in northwestern Gondwana from 260 to $220 \mathrm{Ma}$ is related to a change in plate vector kinematics, resulting in thermal weakening of the subduction slab and eventually slab breakoff. They interpreted the subsequent upwelling of the asthenophere as the cause of basaltic magma emplacement at the base of the lower crust triggering a vast region of extensive crustal melting from 260 to $200 \mathrm{Ma}$ along the western Gondwana. Our model is similar except that we propose that slab breakoff occurred when South America resumed its course northward after a period of $\sim 30 \mathrm{Ma}$ of progressive slab verticalization ultimately reaching the forearc regions. Slab breakoff likely provoked an isostatic rebound of the oceanic plate, thus accounting for the tectonic underplating of the Arenillas-Panupalí blueschist unit (Fig. 13c) at $\sim 226 \mathrm{Ma}$ and underplating of oceanic material in Colombia in late Triassic (Bustamante et al., 2011). The latter process would explain the rapid cooling of both the Piedras unit and the El Oro metamorphic complex ( 226 Ma).

\section{Conclusion}

The results of our detailed thermobarometric study of the El Oro metamorphic complex, and the evolution of the Late Triassic paired metamorphic belt of southwestern Ecuador can be summarized as follows. After a period of relatively limited thinning of the continental crustal, melting of the Paleozoic psammite-pelite sequence of the La Bocana unit started at $\sim 229$ Ma. Crustal thinning and emplacement of the Piedras gabbroic unit provided the heat source that enhanced crustal anatexis. Melting of the metasediments occurred through white-mica and biotite dehydration processes. In the biotite dehydration melting zone, garnet was produced as the main peritectic phase, while modal percentage of biotite and sillimanite decreased with increasing metamorphic conditions. $P-T$ conditions estimates showed that crustal anatexis started at about $650{ }^{\circ} \mathrm{C}$ and $\sim 4.5 \mathrm{kbar}$, and reach maximum of $820^{\circ} \mathrm{C}$. On a $7 \mathrm{~km}$ thick layer the apparent geotherm was of about $40{ }^{\circ} \mathrm{C} / \mathrm{km}$ in the upper crustal unit and $5{ }^{\circ} \mathrm{C} / \mathrm{km}$ in the lower unit. In the lower unit we suggest that temperature was buffered by biotite dehydration melting and by convective motions of magmas. The occurrence of numerous granite intrusions during Triassic times along the South American margin indicates that western South American underwent a widespread thermal anomaly between 230 and $225 \mathrm{Ma}$, which produced large amounts of S-type granitoids. We attribute the tectono-thermal event to a slab break-off event due to eastward migration of South America during Permian-Triassic times. Slab breakoff and/or slab verticalisation provoked upwelling and decompression of the asthenosphere, which underwent partial melting and provoked the magmatic underplating of the MORB-type Piedras gabbroic unit. This tectono-thermal event was immediately followed by renewed subduction processes and the underplating of the Arenillas-Panupalí blueschist unit, which strongly contributed to the rapid cooling down of the forearc region of southwestern Ecuador by $\sim 226 \mathrm{Ma}$. 


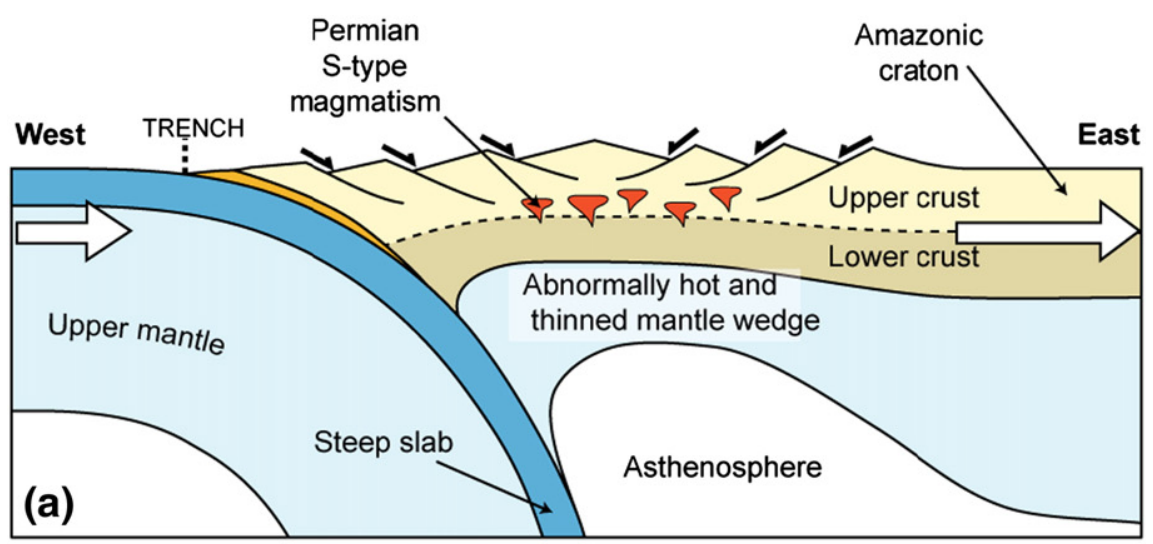

EARLY TO MIDDLE TRIASSIC (250-235 Ma)

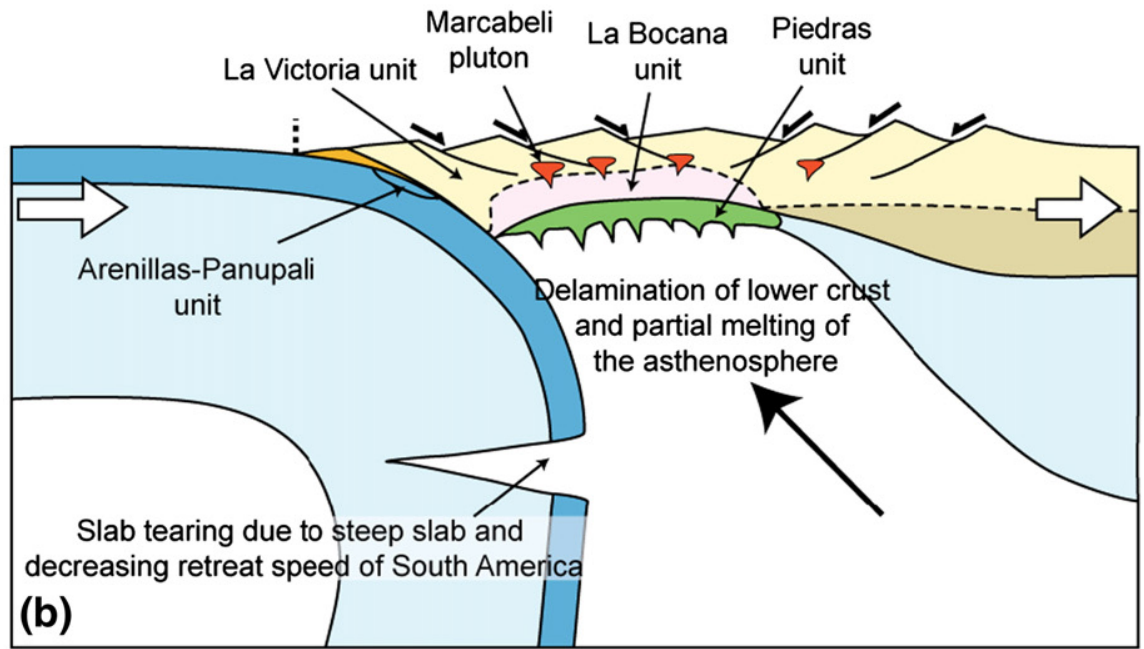

EARLY LATE TRIASSIC (235-225 Ma)

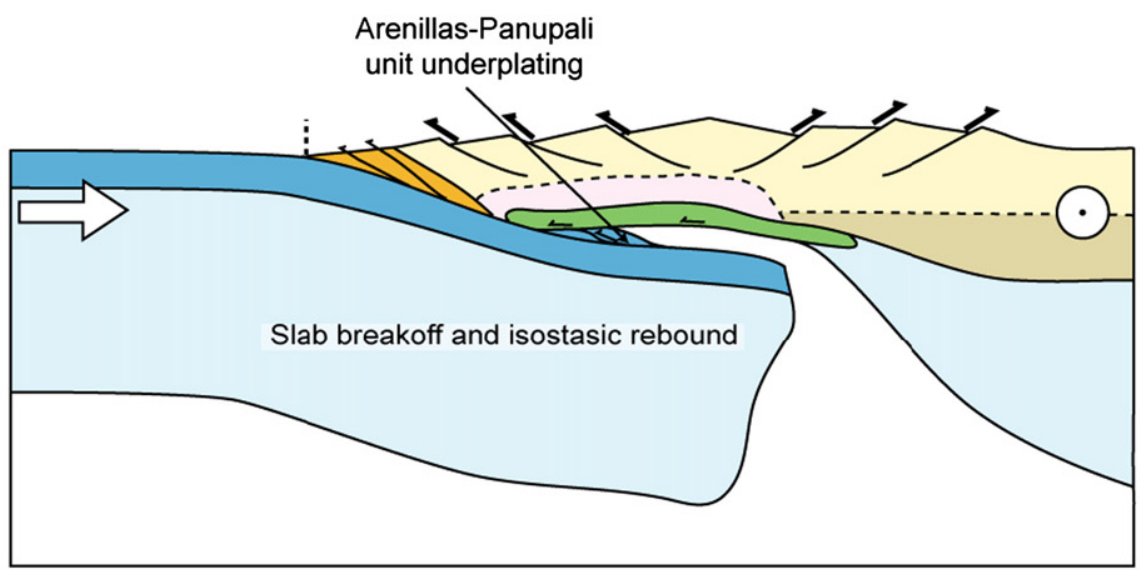

LATE TRIASSIC (225-220 Ma)

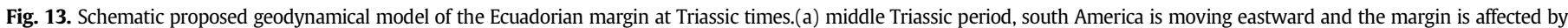

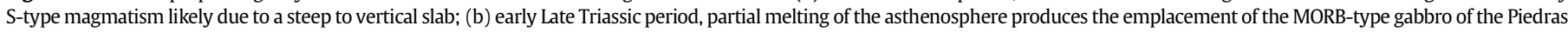

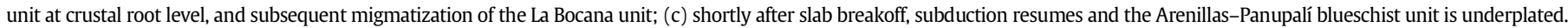

\section{Acknowledgements}

This research was funded by the SEDIT programme (INSU, 2008-2009). We thank the IRD-Quito for logistical support during the 2008 and 2010 field campaigns. We thank Francis Coeur, François Senebier, Jean-Luc Devidal and Gilles Montagnac, for their help in sample preparation, microprobe and Raman analysis. We thank the Laboratoire de Géologie de Lyon (ENS-Lyon) to give us access to the national Raman instrument supported by INSU CNRS. We are grateful to Michael Gazley and Louise Fisher for the thorough and constructive reviews of the manuscript. We also thank Bernado Cesare, Diego Villagomez and David Chew for 
their constructive reviews which have contributed to a much improved manuscript.

\section{Appendix A. Analytical techniques}

\section{Raman study of carbonaceous material}

We used Raman spectroscopy on carbonaceous matter (RSCM) in metasediments of middle to high metamorphic grade. The Raman spectra of carbonaceous matter are characterized by three bands. The band centered at $\sim 1580 \mathrm{~cm}^{-1}$ is interpreted as the $G$ band and corresponds to the vibration mode of aromatic carbon in the graphitic structure. The band centered at $\sim 1350 \mathrm{~cm}^{-1}$ is interpreted as the D1 band and is attributed as the presence of heteroatoms $(\mathrm{O} . \mathrm{H} . \mathrm{N})$ or defects in the structure. The third band centered at $\sim 1620 \mathrm{~cm}^{-1}$ is the D2 band and is attributed to out-plane defects (Bény-Bassez and Rouzaud, 1985). Graphitization is a process observed in metamorphic rocks and corresponds to the solid-state transformation of organic matter into carbonaceous mineral. Graphitization is thermally dependent and can be used a geothermometer (Beyssac et al., 2002). This geothermometer is based on the estimation of the area ratio R2 calculated from the three characteristic bands (D1. D2 and G).

In this study Raman spectroscopy was performed at the Ecole Normale Supérieure de Lyon, France, with a Horiba Jobin-YvonLabRam apparatus. The light source was an argon-ion laser to achieve $514.5 \mathrm{~nm}$ wavelengths. An Olympus ${ }^{\mathrm{TM}}$ BX30 open microscope equipped with a $\times 50$ long-working distance objective was coupled to a spectrometer to focus the laser output power on the sample to a $3 \mu \mathrm{m}$ spot diameter. The Raman signal was collected in the backscattered direction. Acquisition time was $90 \mathrm{~s}$ distributed over three accumulation cycles. with a laser output power on the sample of $0.7 \mathrm{~mW}$. The spectral resolution was $1 \mathrm{~cm}^{-1}$ using $600 \mathrm{~g} / \mathrm{mm}$ grating. The spectral region from 1200 to 1800 was investigated in order to characterize the vibration mode of carbonaceous matter following the method proposed by Beyssac et al. (2002). Treatments of the RSCM data were undertaken using Peakfit software.

\section{Microprobe}

Mineral chemistry has been studied by microprobe analysis on thin-sections, using a CAMECA SX 100 microprobe at the Laboratoire Magma et Volcans of the university of Clermont-Ferrand) with $15 \mathrm{kV}$ acceleration potential and $15 \mathrm{nA}$ beam current. Representative analyses of minerals are presented in Tables 1 and 2. Acquisition of the garnet map of the Fig. 8 was done on the same microprobe, with $15 \mathrm{kV}$ acceleration potential, $100 \mathrm{nA}$ beam current and $300 \mathrm{~ms}$ counting time.

\section{Whole-rock chemistry}

Whole-rock analyses were performed at ISTerre (University of Grenoble. France) and are presented in Table 4. Concentrations of major elements were determined by ICP-AES using a Perkin Elmer 3000 DV spectrometer using the method of Cotten et al. (1995).

\section{Geochronology}

\section{Monazite geochronology}

$\mathrm{U}-\mathrm{Th}-\mathrm{Pb}$ geochronology of monazite was conducted by laser ablation inductively coupled plasma spectrometry (LA-ICPMS) at the university of Clermont-Ferrand, on thin sections. The analyses involve the ablation of minerals with a Resonetics Resolution M-50 powered by an ultra short pulse ATL Atlex Excimer laser system operating at a wavelength of $193 \mathrm{~nm}$ (detailed description in Müller et al., 2009). Spot diameters of $7 \mu \mathrm{m}$ with repetition rates of $3 \mathrm{~Hz}$ and $1 \mathrm{~Hz}$ were used. The ablated material is carried into helium, and then mixed with nitrogen and argon before injection into a plasma source of an Agilent 7500 cs ICP-MS equipped with a dual pumping system to enhance the sensitivity.

The alignment of the instrument and mass calibration was performed before every analytical session using the NIST SRM 612 reference glass. by inspecting the signal of ${ }^{238} \mathrm{U}$ and by minimizing the $\mathrm{ThO}^{+} / \mathrm{Th}^{+}$ratio $(<<1 \%)$. The mean sensitivity on ${ }^{238} \mathrm{U}$ at the instrumental conditions reported in Table 7 and using a spot size of $44 \mu \mathrm{m}$ is about $15-20,000 \mathrm{cps} / \mathrm{ppm}$. The analytical method for isotope dating of monazite with laser ablation ICPMS is basically similar to that developed for zircon and monazite and reported in Tiepolo (2003) and Paquette and Tiepolo (2007). The signal of the ${ }^{204}(\mathrm{~Pb}+\mathrm{Hg}) .{ }^{206} \mathrm{~Pb}$. ${ }^{207} \mathrm{~Pb} .{ }^{208} \mathrm{~Pb}$. ${ }^{232} \mathrm{Th}$ and ${ }^{238} \mathrm{U}$ masses are acquired. The occurrence of common $\mathrm{Pb}$ in the sample can be monitored by the evolution of the ${ }^{204}(\mathrm{~Pb}+\mathrm{Hg})$ signal intensity, but no common $\mathrm{Pb}$ correction was applied owing to the large isobaric interference from $\mathrm{Hg}$. The ${ }^{235} \mathrm{U}$ signal is calculated from ${ }^{238} \mathrm{U}$ on the basis of the ratio ${ }^{238} \mathrm{U} /{ }^{235} \mathrm{U}=137.88$. Single analyses consisted of $30 \mathrm{~s}$ of background integration with the laser off followed by $1 \mathrm{~min}$ integration with the laser firing and a $30 \mathrm{~s}$ delay to wash out the previous sample (approximately $10 \mathrm{~s}$ for a 6 order of magnitude decrease in signal intensity) and prepare the next analysis.

Data are corrected for $\mathrm{U}-\mathrm{Pb}$ and $\mathrm{Th}-\mathrm{Pb}$ fractionation occurring during laser sampling and for instrumental mass discrimination (mass bias) by standard bracketing with repeated measurements of the Moacir monazite standard (Gasquet et al., 2010). At the beginning and at the end of every run, repeated analyses of the Manangoutry monazite (Paquette and Tiepolo, 2007) standard were treated as unknowns to independently control the reproducibility and accuracy of the corrections. Data reduction was carried out with the software package GLITTER ${ }^{\circledR}$ developed by the Macquarie Research Ltd. (Jackson et al., 2004; van Achterbergh et al., 2001). For each analysis, the time resolved signal of single isotopes and isotope ratios was monitored and carefully inspected to verify the presence of perturbations related to inclusions, fractures, mixing of different age domains or common $\mathrm{Pb}$. Calculated ratios were exported and Concordia ages and diagrams were generated using Isoplot/Ex v. 2.49 software package of Ludwig (2003). The concentrations in U-Th-Pb were calibrated relative to the certified contents of 91500 zircon standard (Wiedenbeck, 1995) and Moacir monazite (Seydoux-Guillaume et al., 2004).

\section{Zircon geochronology}

Zircon grains were handpicked from the concentrate. Crystals were mounted in epoxy resin with several chips of the BR266 standard zircon standard (903 ppm U corresponding to an age of $559 \mathrm{Ma}$ ) on $25 \mathrm{~mm}$ diameter mounts and polished to expose zircon cross-sections. The polished mounts were carbon-coated prior to SEM examination. Zircons were imaged using a JEOL 6400 Scanning Electron Microscope at the Centre for Microscopy and Microanalysis at the University of Western Australia. Backscattered electron and cathodoluminescence $(\mathrm{CL})$ images were obtained for all the mounts, and were used to characterize each grain in terms of size growth morphology and internal structure. The carbon coat was removed and the mount gold-coated for SHRIMP analysis.

Isotope analyses were performed using the SHRIMP II ion microprobe at Curtin University of Technology, Western Australia using the standard operating conditions described by Compston et al. (1992) and Smith et al. (1998). The spot size used during all the sessions was around $20 \mu \mathrm{m}$. In this study, six data collection cycles (scans) were performed per analysis and count times (per scan) were $10 \mathrm{~s}$ for the ${ }^{204} \mathrm{~Pb}$. ${ }^{206} \mathrm{~Pb}$ and ${ }^{208} \mathrm{~Pb}$ mass peaks and background and $30 \mathrm{~s}$ for the ${ }^{207} \mathrm{~Pb}$ mass peak. Unknown analyses were referenced to multiple analyses of the BR266 standard for U/Pb calibration. Standard analyses performed throughout each analysis session gave $1 \sigma$ uncertainties of $2.0 \%$ or less for $\mathrm{Pb} * / \mathrm{U}$ Data reduction was carried out with the software package SQUID v1.10 and ISOPLOT v3.0 (Ludwig, 2003). Corrections for common Pb content were based on measured ${ }^{204} \mathrm{~Pb}$ and assuming contemporary values for common $\mathrm{Pb}$ derived from Stacey and Kramers (1975). 


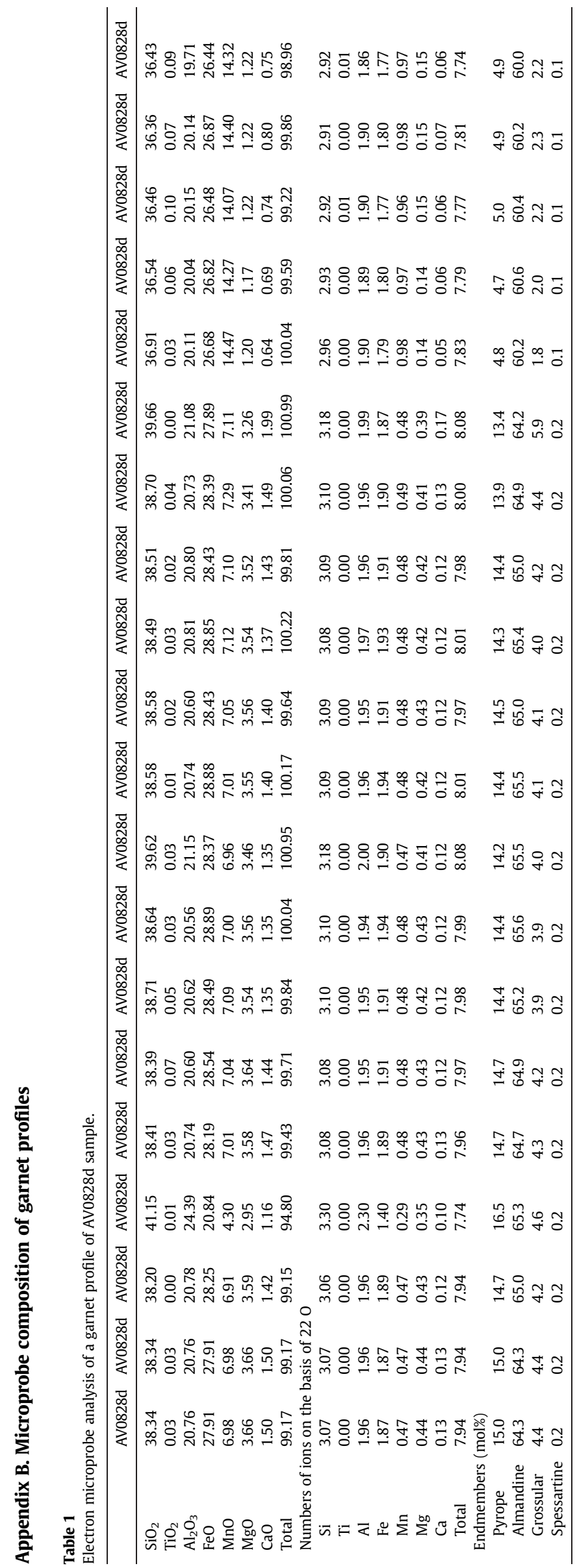

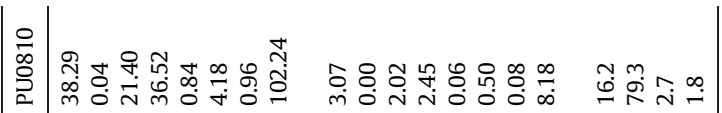

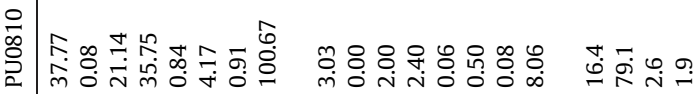

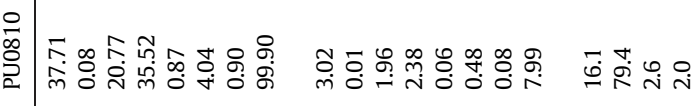

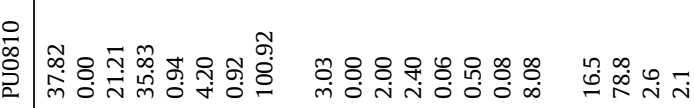

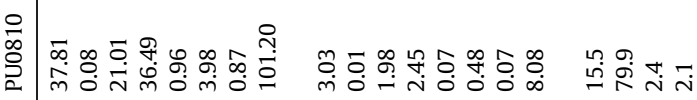

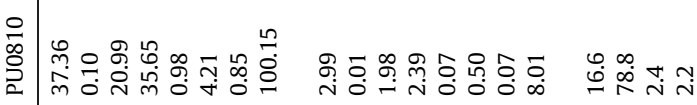

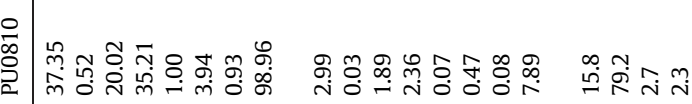

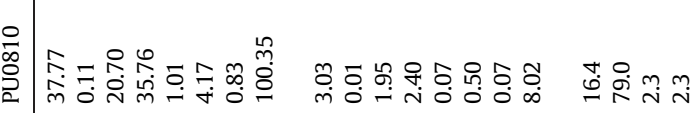

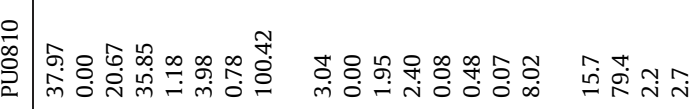

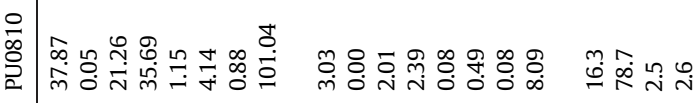

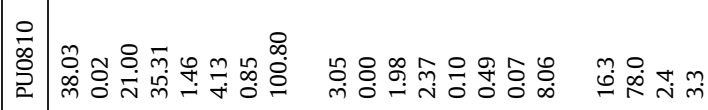

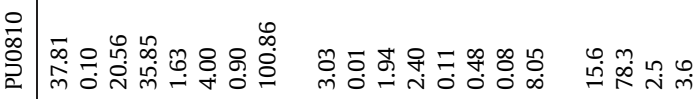
要

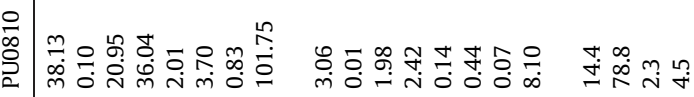

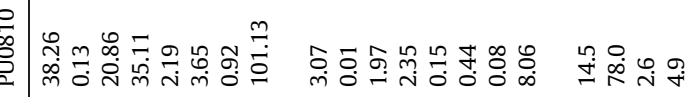

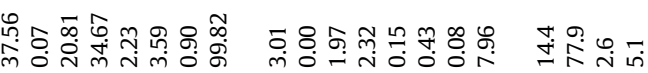
응

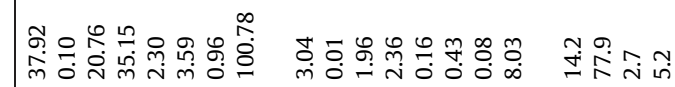

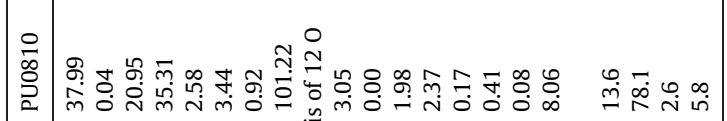

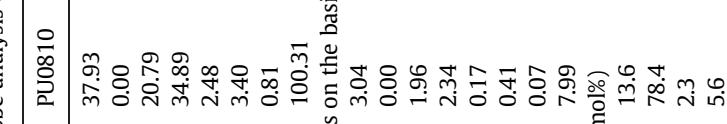

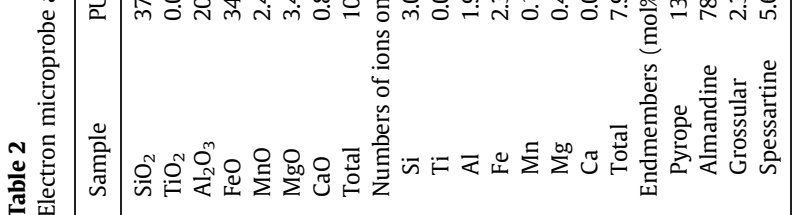




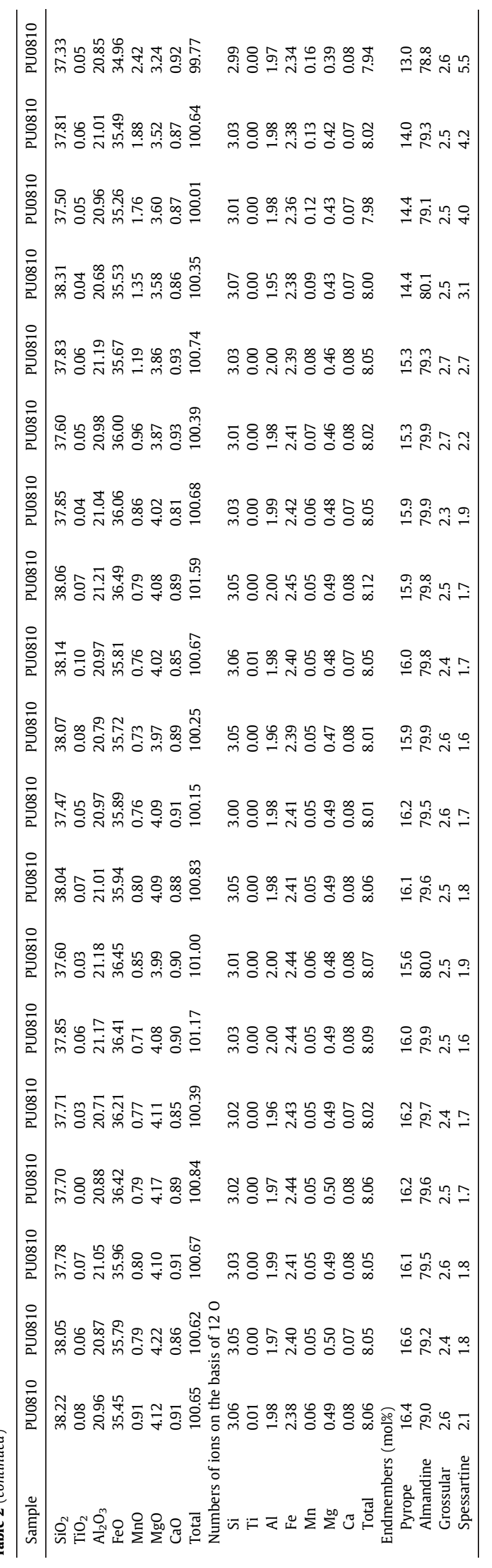

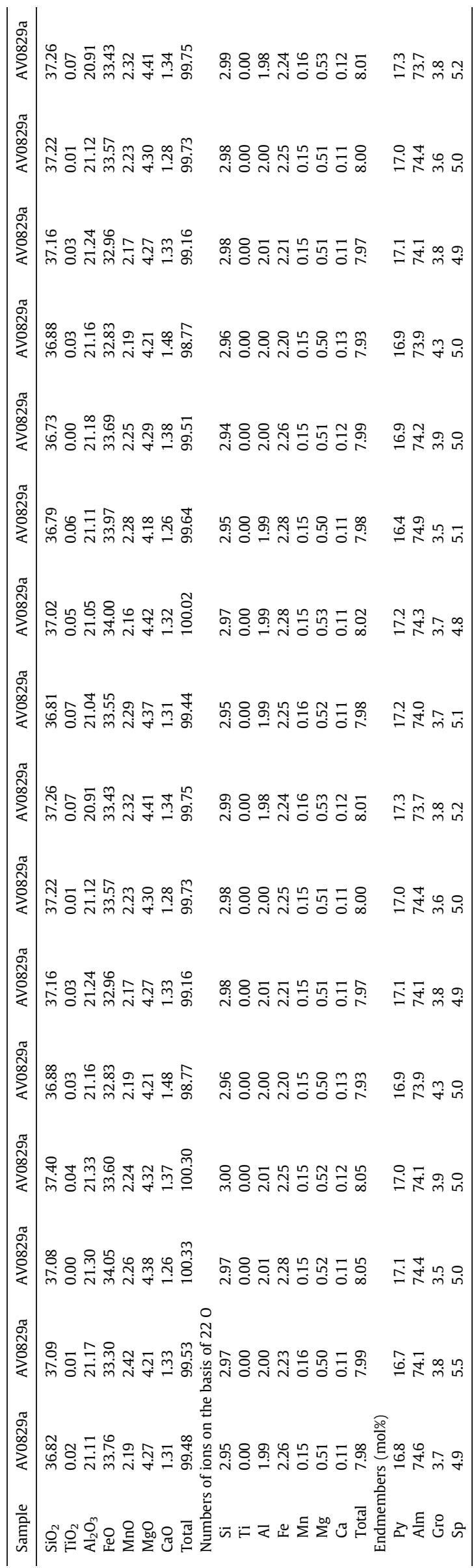




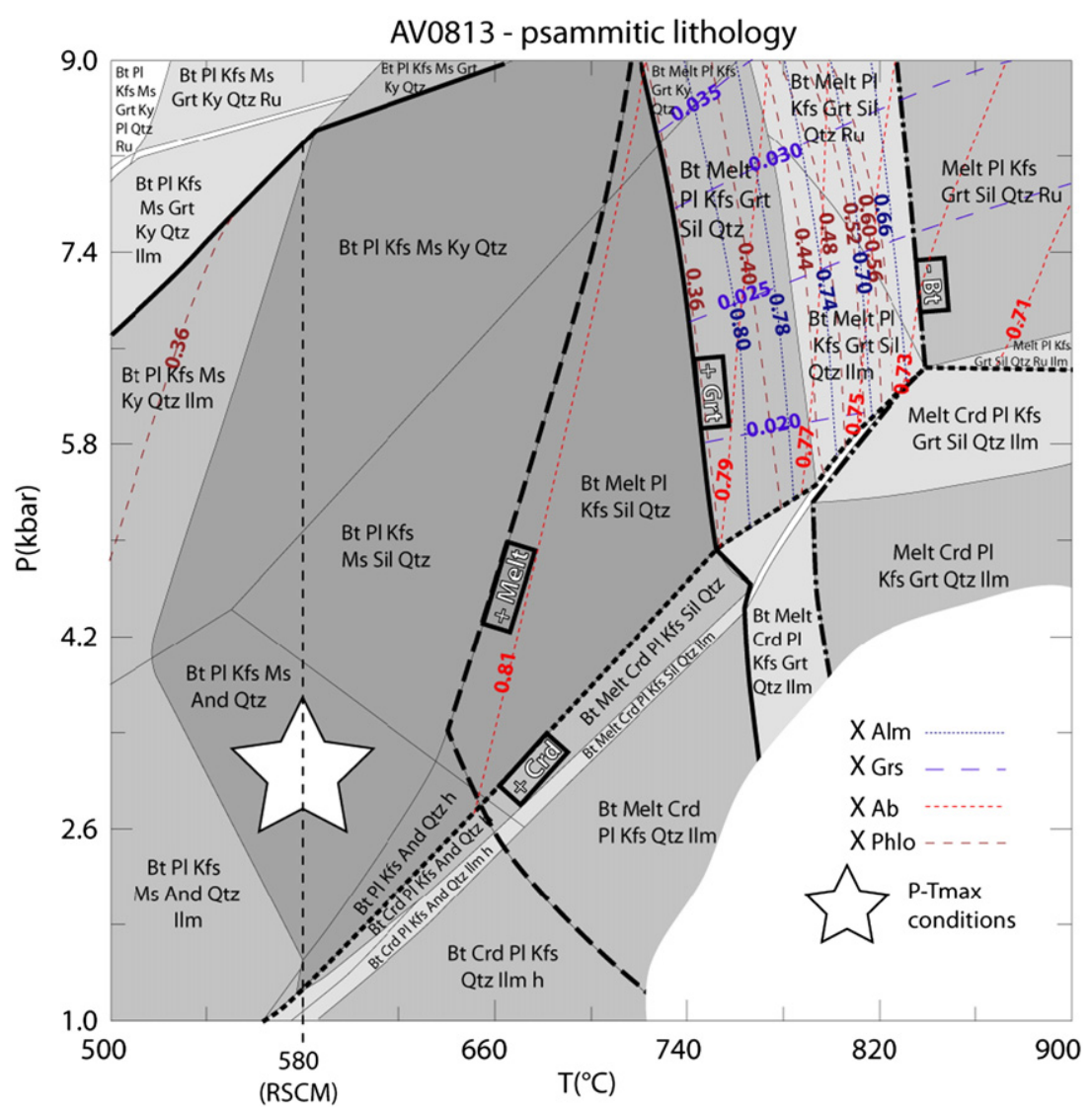

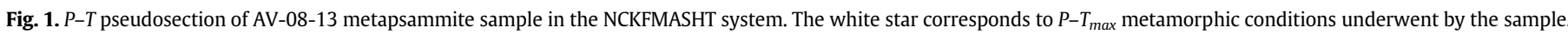

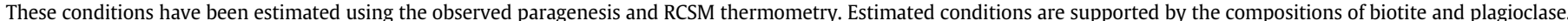

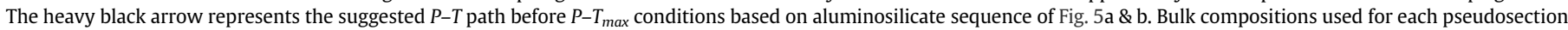
are reported in Table 5. No shading = field divariant, then light to dark shading = increasing the variance (trivariant, quadrivariant, etc.).

The sample AV-08-13 represents the psammitic endmember lithology which in the lower the La Bocana unit underwent partial melting under biotite dehydration melting. In order to validate this hypothesis, $X_{A l m}, X_{G r s}$ isopleths of garnet and $X_{P h l o}, X_{A b}$ of biotite and plagioclase are also indicated in the suprasoludis region. Reported isopleth of solid-solutions in suprasolidus region are compatible with measured compositions in samples AV-08-28d, AV-08-32a, AV-08-33 and PU-08-10 ( $X_{\text {Alm }}, 0.72$ to $0.80 ; X_{G r s}, 0.025$ to $0.045 ; X_{P h l o}, 0.5$ to $0.6, X_{A b}$, 0.6 to 0.7 ) and also indicate that partial melting occurred under biotite dehydration melting at $P-T$ conditions of 5 to 8 kbar and 740 to $820^{\circ} \mathrm{C}$. 


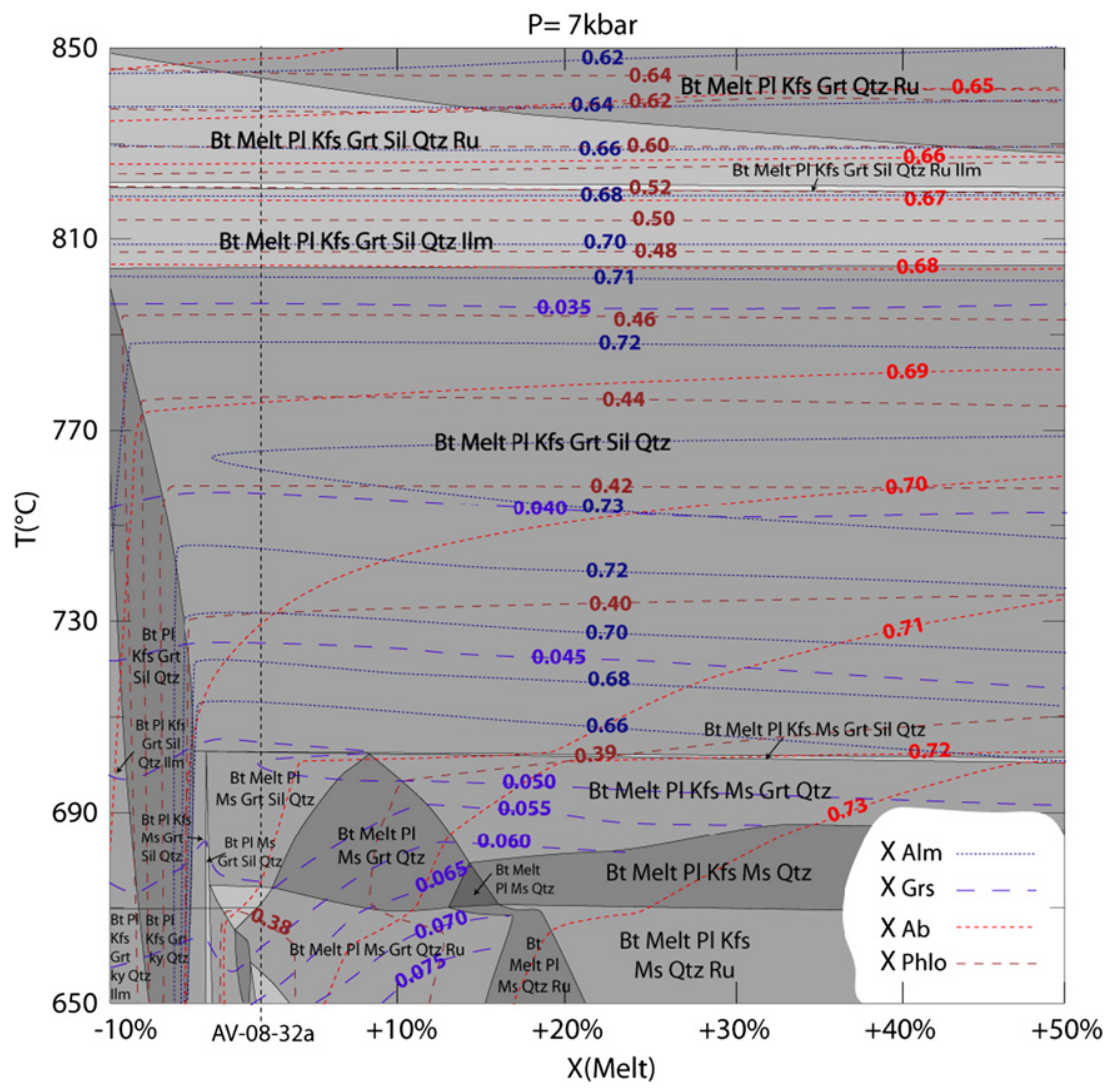

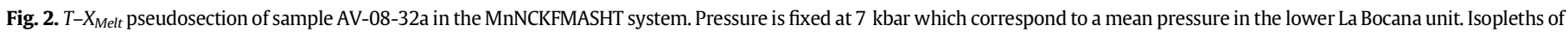

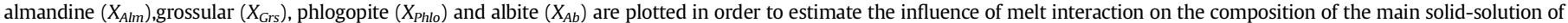

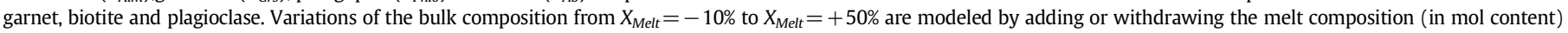

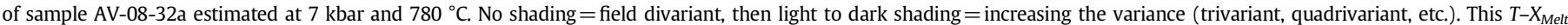

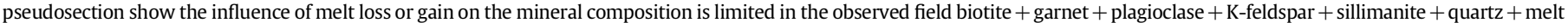
field and supports the $P-T$ results of the garnet-bearing migmatites. 


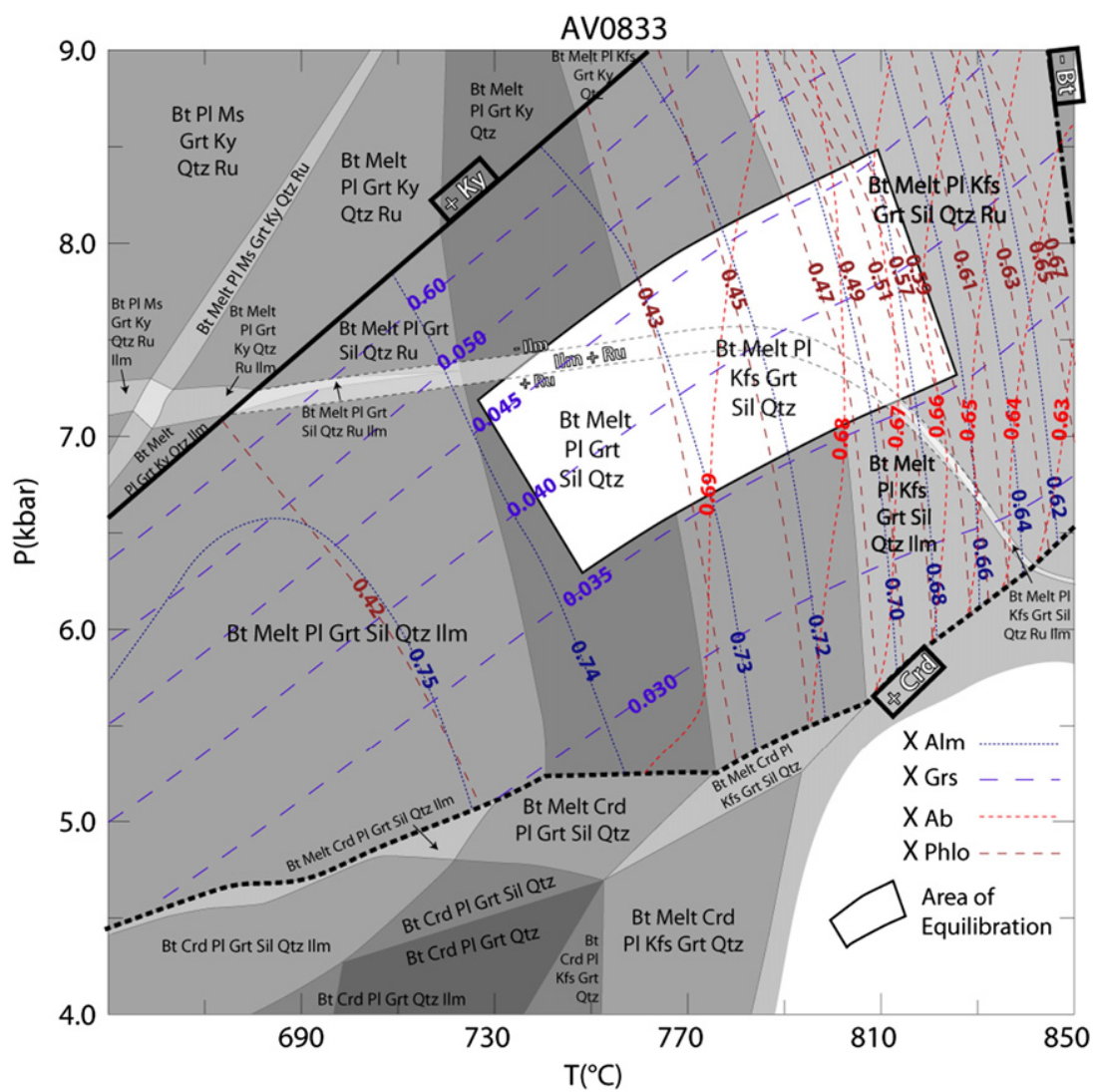

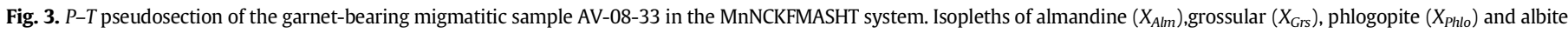

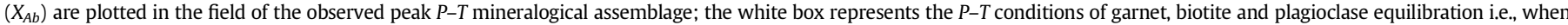

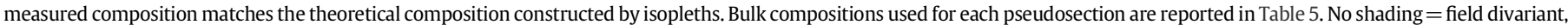
then light to dark shading = increasing the variance (trivariant, quadrivariant, etc.). 


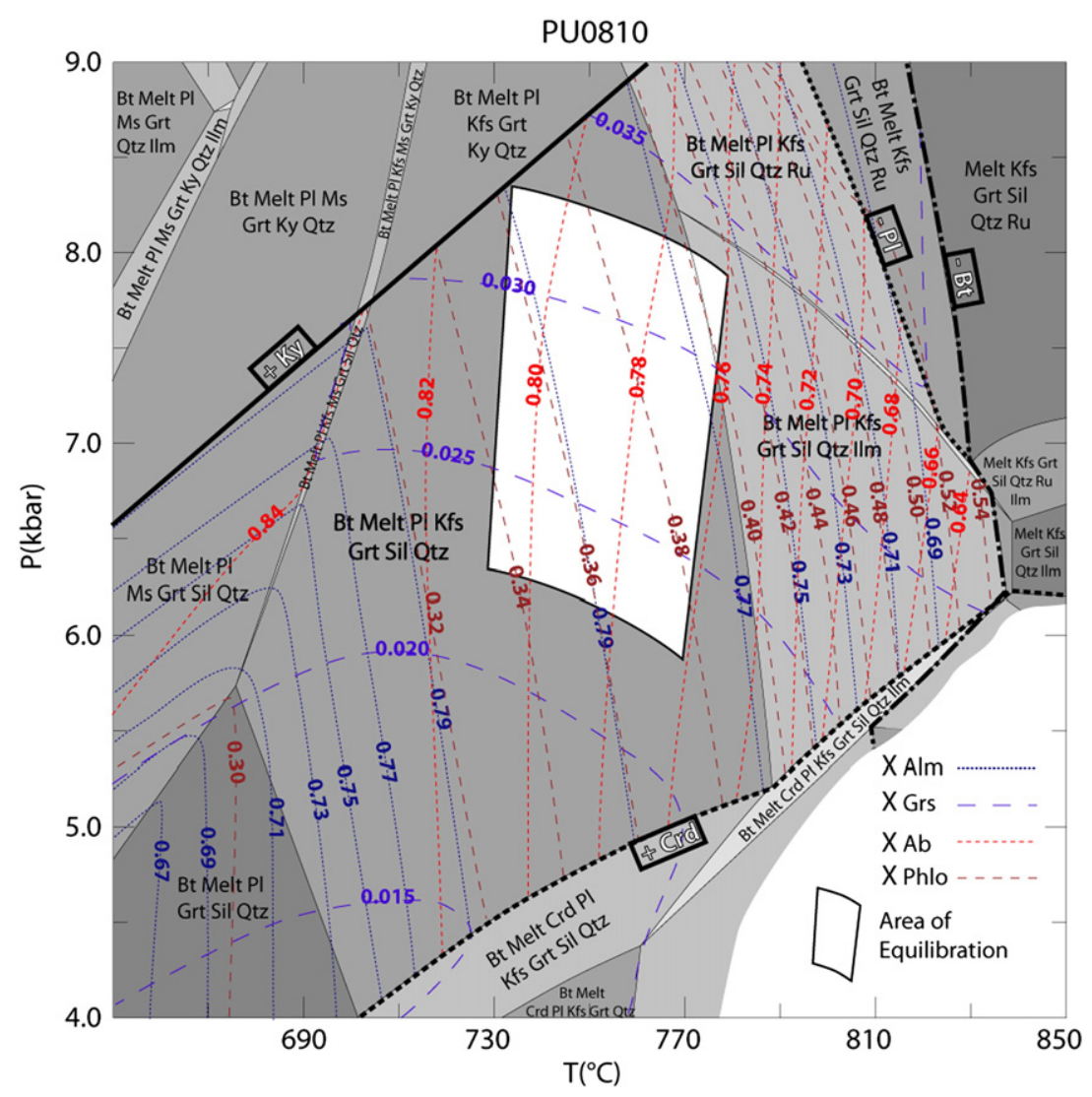

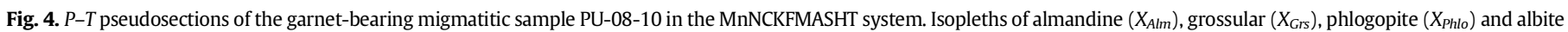

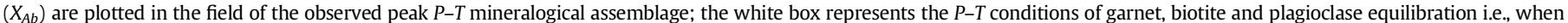

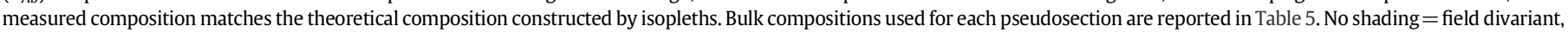
then light to dark shading=increasing the variance (trivariant, quadrivariant, etc.).

\section{References}

Aspden, J.A., Litherland, M., 1992. The geology and Mesozoic collisional history of the Cordillera Real, Ecuador. Tectonophysics 205, 187-204.

Aspden, J.A., Fortey, N., Litherland, M., Viteri, F., Harrison, S.M., 1992a. Regional S-type granites in the Ecuadorian Andes: possible remnants of the breakup of western Gondwana. Journal of South American Earth Sciences 6, 123-132.

Aspden, J.A., Harrison, S.H., Rundle, C.C., 1992b. New geochronological control for the tectonomagmatic evolution of the metamorphic basement, cordillera rea and El-oro province of Ecuador. Journal of South American Earth Sciences 6, 77-96.

Aspden, J.A., Bonilla, W., Duque, P., 1995. The El Oro Metamorphic Complex, Ecuador: Geology and Economic Mineral Deposits. Overseas Geology and Mineral Resources (British Geological Survey publication), 67 . (combien de pages ?).

Bény-Bassez, C., Rouzaud, J.N., 1985. Characterization of carbonaceous materials by correlated electron and optical microscopy and Raman microspectroscopy. Scanning Electron Microscopy. SEM Inc., Chicago, pp. 119-132.

Bergantz, G.W., 1992. Conjugate solidification and melting in multicomponent open and closed systems. International Journal of Heat and Mass Transfer 35, 533-543.

Beyssac, O., Goffé, B., Chopin, C., Rouzaud, J.N., 2002. Raman spectra of carbonaceous material in metasediments: a new geothermometer. Journal of Metamorphic Geology 20, 859-871.

Beyssac, O., Bollinger, L., Avouac, J.-P., Goffé, B., 2004. Thermal metamorphism in the lesser Himalaya of Nepal determined from Raman spectroscopy of carbonaceous materiel. Earth and Planetary Science Letters 225, 233-241.

Bosch, D., Gabriele, P., Lapierre, H., Malfere, J.-L., Jaillard, E., 2002. Geodynamic significance of the Raspas Metamorphic Complex (SW Ecuador): geochemical and isotopic constraints. Tectonophysics 345, 83-102.

Brown, M., 2002. Retrograde processes in migmatites and granulites revisited. Journal of Metamorphic Geology 20, 25-40.

Brown, M., 2007. Metamorphism, plate tectonics, and the supercontinent cycle. Earth Science Frontiers 14, 1-18.

Bustamante, A., Juliani, C., Hall, C.M., Essene, E.J., 2011. 40Ar/39Ar ages from blueschists of the Jambaló region, Central Cordillera of Colombia: implications on the styles of accretion in the Northern Andes. Geologica Acta 9, 351-362.

Cardona, A., Valencia, V., Garzó, n, A., Montes, G, Ojeda, G., Ruiz, J., Weber, M. 2010. Permian to Triassic I to S-type magmatic switch in the northeast Sierra Nevada de Santa Marta and adjacent regions, Colombian Caribbean: tectonic setting and implications within Pangea paleogeography. Journal of South American Earth Sciences 29, 772-783.Carrington, D.P., Watt, G.R., 1995. A geochemical and experimental study of the role of $\mathrm{K}$-feldspar during water-undersaturated melting of metapelites. Chemical Geology 122, 59-76.

Cesare, B., 1994. Hercynite as the product of staurolite decomposition in the contact aureole of Vedrette di Ries, eastern Alps, Italy. Contributions to Mineralogy and Petrology 116, 239-246.

Chew, D.M., Schaltegger, U., Košler, J., Whitehouse, M.J., Gutjahr, M., Spikings, R.A., Miškovic, A., 2007. U-Pb geochronologic evidence for the evolution of the Gondwanan margin of the north-central Andes. Geological Society of America Bulletin 119, 697-711.

Chew, D.M., Magna, T., Kirkland, C.L., Miskovic, A., Cardona, A., Spikings, R., Schaltegger, U., 2008. Detrital zircon fingerprint of the Proto-Andes: evidence for a Neoproterozoic active margin? Precambrian Research 167, 186-200.

Cloos, M., Shreve, R.L., 1996. Shear-zone thickness and the seismicity of Chilean- and Marianas-type subduction zones. Geology 24, 107-110.

Compston, W., Williams, I.S., Kirschvink, J.L., Zichao, Zh., Guogan, M., 1992. Zircon ages for the Early Cambrian timescale. Journal of the Geological Society of London 149, $171-184$.

Connolly, J.A.D., 2005. Computation of phase equilibria by linear programming: a tool for geodynamic modeling and its application to subduction zone decarbonation. Earth and Planetary Science Letters 236, 524-541.

Connolly, J.A.D., Cesare, B., 1993. C-O-H-S fluid composition and oxygen fugacity in graphitic metapelites. Journal of Metamorphic Geology 11, 379-388.

Cotten, J., Le Dez, A., Bau, M., Caroff, M., Maury, R.C., Dulski, P., Fourcade, S., Bohn, M., Brousse, R., 1995. Origin of anomalous rare-earth element and yttrium enrichments in subaerially exposed basalts: evidence from French Polynesia. Chemical Geology 119, 115-138.

Depine, G.V., Andronicos, C.L., Phipps-Morgan, J., 2008. Near-isothermal conditions in the middle and lower crust induced by melt migration. Nature $452,80-83$.

Ernst, W.G., 1988. Tectonic history of subduction zones inferred from retrograde blueschist P-T paths. Geology 16, 1081-1084.

Farrar, E., Clark, A., Heinrich, S., 1990. The age of the Zongo pluton and the tectonothermal evolution of the Zongo San-Gaban zone int the Cordiellera Real, Bolivia. Internat. Symp. Andean Geodynamics, Grenoble, Abstract book.

Feininger, T., 1978. Geologic map of Western El Oro Province. Escuela Politecnica Nacional, Quito, Ecuador.

Feininger, T., 1980. Eclogite and related high-pressure regional metamorphic rocks from the Andes of Ecuador. Journal of Petrology 21, 107-140.

Feininger, T., Silberman, M.L., 1982. K-Ar Geochronology of Basement Rocks on the Northen Flank of the Huancabamba Deflection, Ecuador. U.S. Geological survey (Open-file report), pp. 82-206. 
Ferry, J.M., Spear, F.S., 1978. Experimental calibration of the partitioning of Fe and $\mathrm{Mg}$ between biotite and garnet. Contributions to Mineralogy and Petrology 66, 113-117.

Gabriele, P., 2002. HP Terranes exhumation in an active margin setting: geology, petrology and geochemistry of the Raspas complex in SW Ecuador. Unpub. PhD Thesis, Lausanne University, Switzerland.

Gabriele, P., Ballèvre, M., Jaillard, E., Hernandez, J., 2003. Garnet-chloritoid-kyanite metapelites from the Raspas Complex (SW Ecuador): a key eclogite-facies assemblage. European Journal of Mineralogy 15, 977-989.

Gardien, V., Lardeaux, J.M., Ledru, P., Allemand, P., Guillot, S., 1997. Metamorphism during late orogenic extension: insights from the French Variscan belt. Bulletin de la Société Géologique de France 168, 271-286.

Gasquet, D., Bertrand, J.M., Paquette, J.L., Lehmann, J., Ratzov, G., Guedes, R.D., Tiepolo, M., Boullier, A.M., Scaillet, S., Nomade, S., 2010. Miocene to Messinian deformation and hydrothermal activity in a pre-Alpine basement massif of the French western Alps: new $\mathrm{U}-\mathrm{Th}-\mathrm{Pb}$ and argon ages from the Lauziere massif. Bulletin de la Société Géologique de France 181, 227-241.

Geunal, S.E., Escosteguy, D., Limarino, C.O., 2010. Paleomagnetism of the CarboniferousPermian Patquía Formation, Paganzo basin, Argentina: implications for the apparent polar wander path for South America and Gondwana during the Late Palaeozoic. Geologica Acta 8, 373-397.

Guillot, S., Hattori, K., Agard, P., Schwartz, S., Vidal, O., 2009. Exhumation processes in oceanic and continental subduction contexts: a review. In: Lallemand, S., Funiciello, F. (Eds.), Subduction Zone Dynamics. Springer-Verlag, Berlin Heidelberg, pp. 175-204.Holland, T.J.B., Powell, R., 1998. An internally consistent thermodynamic dataset for phases of petrological interest. Journal of Metamorphic Geology 16, 309-343.

Harrison, T.M., McDougall, I., 1981. Excess ${ }^{40} \mathrm{Ar}$ in metamorphic rocks from Brocken Hill, South Wales: implications for ${ }^{40} \mathrm{Ar} /{ }^{39} \mathrm{Ar}$ age spectra and the thermal history of the region. Earth and Planetary Science Letters 55, 123-149.

Hodges, K.V., 2000. Tectonics of the Himalaya and southern Tibet from two perspectives. Geological Society of America Bulletin 112, 324-350.

Holland, T.J.B., Powell, R., 1998. An internally-consistent thermodynamic dataset for phases of petrological interest. Journal of Metamorphic Geology 16, 309-344.

Huppert, H.E., Sparks, R.S.J., 1988. The generation of granitic magmas by intrusion of basalt into continental crust. Journal of Petrology 29, 599-624.

Jackson, S.E., Pearson, N.J., Griffin, W.L., Belousova, E.A., 2004. The application of laser ablation-inductively coupled plasma-mass spectrometry to in situ U-Pb zircon geochronology. Chemical Geology 211, 47-69.

Jaillard, É., Ordoñez, M., Bengtson, P., Berrones, G., Bonhomme, M., Jiménez, N., Zambrano, I., 1996. Sedimentary and tectonic evolution of the arc zone of southwestern Ecuador during Late Cretaceous and Early Tertiary times. Journal of South American Earth Sciences 9, 131-140.

Jaillard, E., Laubacher, G., Bengtson, P., Dhondt, A., Bulot, L., 1999. Stratigraphy and evolution of the forearc "Celica-Lancones Basin" of Southwestern Ecuador. Journal of South American Earth Sciences 12, 51-68.

Jaillard, E., Hérail, G., Monfret, T., Díaz Martínez, E., Baby, P., Lavenu, A., Dumont, J.-F., 2000. Tectonic evolution of the Andes of Ecuador, Peru, Bolivia and nothernmost Chile. In: Cordani, U.G., et al. (Ed.), Tectonic evolution of South America, Publ. 31st Internaztional Geological Congress, Rio de Janeiro, pp. 481-559.

John, T., Scherer, E.E., Schenk, V., Herms, P., Halama, R., Garbe-Schönberg, D., 2010. Subducted seamounts in an eclogite-facies ophiolite sequence: the Andean Raspas Complex, SW Ecuador. Contributions to Mineralogy and Petrology 159, 265-284.

Kretz, R., 1983. Symbols for rock-forming minerals. American Mineralogist 68, 277-279.

Kriegsman, L.M., 2001. Partial melting, partial melt extraction and partial back reaction in anatectic migmatites. Lithos 56, 75-96.

Litherland, M., Aspden, J.A., Jemielita, R.A., 1994. The Metamorphic Belts of Ecuador. British Geological Survey. Overseas Memoir, 11. (147 pp.).

Ludwig, K.J., 2003. Isoplot 3.00. Berkeley Geochronology Center (special publication), 4 , pp. $1-70$.

Martínez, M., 1970. Geología del basamento Paleozóico en las Montañas de Amotape y posible origen del petróleo en las rocas Paleozóicas del noreste de Perú. Lima $1^{\text {ero }}$ Congreso Latinoamericano de Geología, No. 2, pp. 105-138.

Mišković, A., Schaltegger, U., Spikings, R.A., Chew, D.M., Košler, J., 2009. Tectono-magmatic evolution of Western Amazonia: geochemical characterisation and zircon U-Pb geochronologic constraints from the Peruvian Eastern Cordilleran granitoids. Geological Society of America Bulletin 121, 1289-1324.

Mourier, T., Laj, C., Mégard, F., Roperch, P., Mitouard, P., Farfan Medrano, A., 1988. An accreted continental terrane in northwestern Peru. Earth and Planetary Science Letters 88, 182-192.

Müller, W., Shelley, M., Miller, P., Broude, S., 2009. Initial performance metrics of a new custom-designed ArF excimer LA-ICPMS system coupled to a two-volume laserablation cell. Journal of Analytical Atomic Spectrometry 24, 209-214.
Newton, R.C., Charlu, T.V., Kleppa, O.J., 1980. Thermochemistry of the high structura state plagioclases. GeCA 44, 933-941.

Noble, S.R., Aspden, J.A., Jemielita, R., Litherland, M., 1994. U-Pb geochronology of the Cordillera Real and the El Oro Provinces, Ecuador. Abstratcs of the Eighth Internationa Conference on Geochronology, Cosmochronology and Isotope Geology, Berkeley California, p. 234.

Noble, S.R., Aspden, J.A., Jemielita, R., 1997. Northern Andean crustal evolution: New U-Pb geochronological constraints from Ecuador. Geological Society of America Bulletin 109, 789-798.

Paquette, J., Tiepolo, M., 2007. High resolution ( $5 \mu \mathrm{m}$ ) U-Th-Pb isotope dating of monazite with excimer laser ablation (ELA)-ICPMS. Chemical Geology 240, 222-237.

Patiño-Douce, A.E., Harris, N.W.B., 1998. Experimental constraints on Himalayan anatexis. Journal of Petrology 39, 689-710.

Patiño-Douce, A.E., Jonhston, A.D., 1991. Phase equilibria and melt productivity in the pelitic system: implications for the origin of peraluminous granitoids and aluminous granulites. Contributions to Mineralogy and Petrology 107, 202-218.

Perchuk, L.L., Lavrent'eva, 1983. Experimental investigation of exchange equilibriain the system cordierite-garnet-biotite. Advances in Physical Geochemistry 3, 199-239.

Restrepo, J.J., Ordóñez-Carmona, O., Armstrong, R., Pimentel, M.M., 2011. Triassic metamorphism in the northern part of the Tahamí Terrane of the central cordillera of Colombia. Journal of South American Earth Sciences 32, 497-507.

Robert, A., Pubellier, M., de Sigoyer, J., Vergne, J., Lahfid, A., Cattin, R., Findling, N., Zhu, J., 2010. Structural and thermal characters of the Longmen Shan (Sichuan, Chian). Tectonophysics 491, 165-173.

Seydoux-Guillaume, A.M., Wirth, R., Deutsch, A., Schärer, U., 2004. Microstructure of 24-1928 Ma concordant monazites: implications for geochronology and nuclear waste deposits. Geochimica et Cosmochimica Acta 68, 2517-2527.

Smith, J.B., Barley, M.E., Groves, D.I., Krapez, B., McNaughton, N.J., Bickle, M.J., Chapman, H.J., 1998. The Scholl shear zone, West Pilbara: evidence for a terrane boundary structure from integrated tectonic analyses, SHRIMP U-Pb dating and isotopic and geochemical data of granitoids. Precambrian Research 88, 143-17.

Spear, F.S., Kohn, M.J., Cheney, J.T., 1999. P-T paths from anatectic pelites. Contributions to Mineralogy and Petrology 134, 17-32.

Stacey, J.S., Kramers, J.D., 1975. Approximation of terrestrial lead isotope evolution by a two-stage model. Earth and Planetary Science Letters 26, 207-221.

Tajcmanová, L., Connolly, J.A.D., Cesare, B., 2009. A thermodynamic model for titanium and ferric iron solution in biotite. Journal of Metamorphic Geology 27, 153-164.

Thompson, A.B., Connolly, J.A.D., 1995. Melting of the continental crust; some thermal and petrological constraints on anatexis in continental collision zones and othe tectonic settings. Journal of Geophysical Research, Solid Earth 100, 15565-15579.

Thompson, A.B., Tracy, R.J., 1979. Model systems for anatexis of pelitic rocks. Contributions to Mineralogy and Petrology 70, 429-438.

Tiepolo, M., 2003. In situ Pb geochronology of zircon with laser ablation-inductively coupled plasma-sector field mass spectrometry. Chemical Geology 199, 159-177.

Tomezzoli, R.N., 2009. The apparent polar wander path for South America during the Permian-Triassic. Gondwana Research 15, 209-215.

Torsvik, T.H., Müller, R.D., Van der Voo, R., Steinberger, B., Gaina, C., 2008. Global plate motion frames: toward a unified model. Reviews of Geophysics 46, 1-44.

Van Achterbergh, E., Ryan, C.G., Jackson, S.E., Griffin, W., 2001. Data Reduction Software for LA-ICP-MS. Laser ablation-ICPMS in the earth science: Mineralogical Association of Canada, 29, pp. 239-243.

Vielzeuf, D., Holloway, J.R., 1988. Experimental determination of the fluid-absent melting relations in the pelitic system. Contributions to Mineralogy and Petrology 98, 257-276.

Vinasco, C., Cordani, U., Gonzalez, H., Weber, M., Pelaez, C., 2006. Geochronological, isotopic, and geochemical data from Permo-Triassic granitic gneisses and granitoids of the Colombian Central Andes. Journal of South American Earth Sciences 21, 355-371.

White, R.W., Powell, R., 2002. Melt loss and the preservation of granulite facies mineral assemblages. Journal of Metamorphic Geology 20, 621-632.

Whitney, D.L., 2002. Coexisting andalusite, kyanite, and sillimanite: sequential formation of three $\mathrm{Al}_{2} \mathrm{SiO}_{5}$ polymorphs during progressive metamorphism near the triple point, Sivrihisar, Turkey. American Mineralogist 87, 405-416.

Wiedenbeck, M., 1995. An example of reverse discordance during ion microprobe zircon dating: an artifact of enhanced ion yields from a radiogenic labile $\mathrm{Pb}$. Chemical Geology 125 (3-4), 197-218.

Willner, A.P., 2005a. Time markers for the evolution and exhumation history of a late palaeozoic paired metamorphic belt in north-central Chile $\left(34^{\circ}-35^{\circ} 30^{\prime} \mathrm{S}\right)$. Journal of Petrology 46, 1835-1858.

Willner, A.P., 2005b. Pressure-temperature evolution of an Upper Paleozoic paired metamorphic belt in Central Chile ( $\left.34^{\circ}-35^{\circ} 30^{\prime} \mathrm{S}\right)$. Journal of Petrology 46, 1805-1833.

Zhu, G., Gerya, T.V., Honda, S., Tackley, P.J., Yuen, D.A., 2011. Influences of the buoyancy of partially molten rock on 3-D plume patterns and melt productivity above retreating slabs. Physics of Earth Planetary Interiors 185, 112-121. 